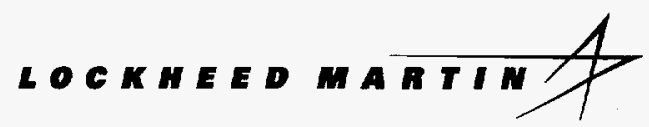

ENVIRONMENTAL

RESTORATION

PROGRAM
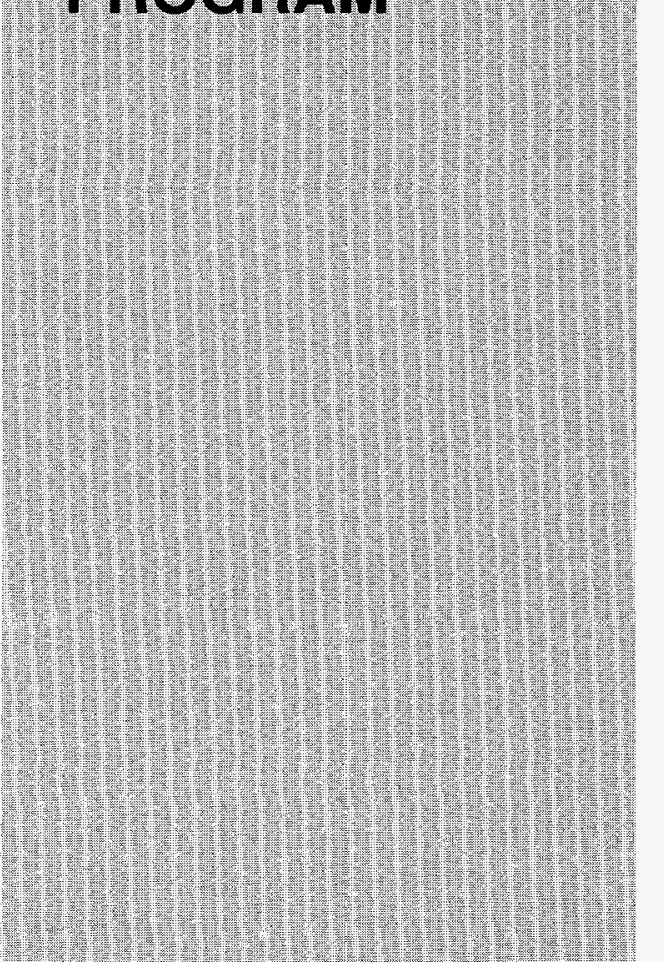

ORNL/ER-382

\section{Safety Analysis Report} for the North Tank Farm, Tank W-11, and the Gunite and Associated Tanks - Treatability Study, Oak Ridge National Laboratory Oak Ridge, Tennessee

\section{RECEIVED}

FFR 281997

\section{OSTI}

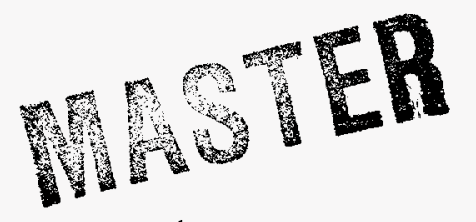

DISTRIBUTTON OF THIS DOCUMENT IS UMLAITEP

This document has been approved by the ORNL Technical Information Office for release to the public. Date: 10/17/96 


\section{Science Applications International Corporation}

contributed to the preparation of this document and should not be considered an eligible contractor for its review. 
ORNL/ER-382

Energy Systems Environmental Restoration Program

Safety Analysis Report for the North Tank Farm, Tank W-11, and the Gunite and Associated Tanks-Treatability Study, Oak Ridge National Laboratory, Oak Ridge, Tennessee

Date Issued-February 1997

\author{
Prepared for the \\ U.S. Department of Energy \\ Office of Environmental Management \\ under budget and reporting code EW 20
}

Environmental Management Activities at the OAK RIDGE NATIONAL LABORATORY

Oak Ridge, Tennessee 37831-8169

managed by

LOCKHEED MARTIN ENERGY SYSTEMS, INC.

for the

U.S. DEPARTMENT OF ENERGY

under contract DE-AC05-84OR21400 


\section{DISCLAMMER}

Portions of this document may be illegible in electronic image products. Images are produced from the best available original document. 


\section{DISCLAIMER}

This report was prepared as an account of work sponsored by an agency of the United States Government. Neither the United States Government nor any agency thereof, nor any of their employees, make any warranty, express or implied, or assumes any legal liability or responsibility for the accuracy, completeness, or usefulness of any information, apparatus, product, or process disclosed, or represents that its use would not infringe privately owned rights. Reference herein to any specific commercial product, process, or service by trade name, trademark, manufacturer, or otherwise does not necessarily constitute or imply its endorsement, recommendation, or favoring by the United States Government or any agency thereof. The views and opinions of authors expressed herein do not necessarily state or reflect those of the United States Government or any agency thereof. 
APPROVALS

Safety Analysis Report for the North Tank Farm, Tank W-11, and Gunite and Associated Tanks-Treatability Study (ORNL/ER-382)

Prepared by:

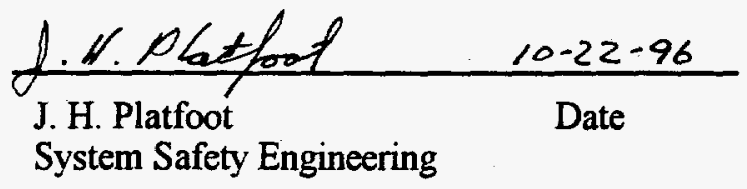

Concurred with by:

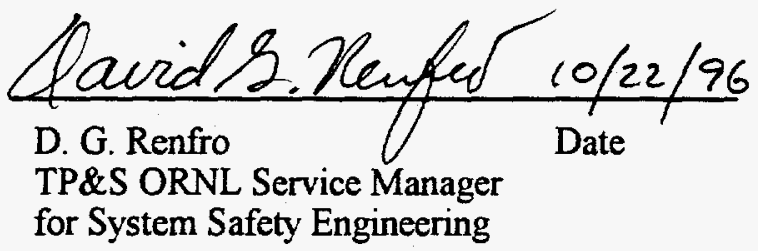

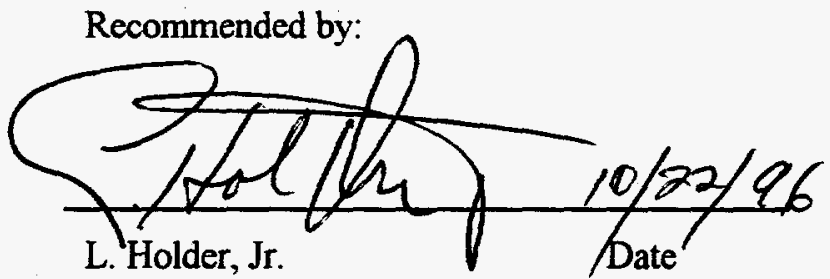

North Tank Farm and W-11 Facility Manager

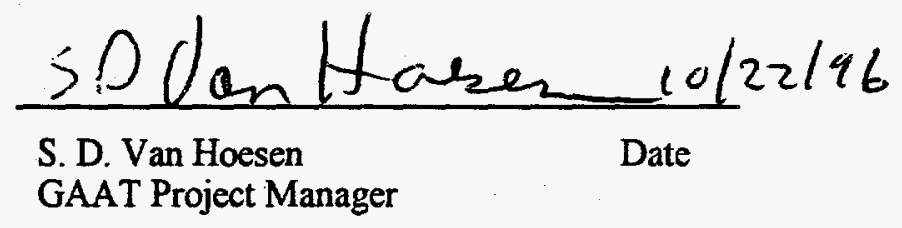

R. S. McKeehan for ORNL Installation Facility Safety Manager

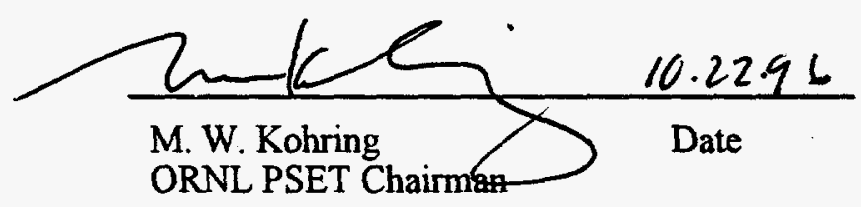




\section{APPROVALS}

\section{Safety Analysis Report for the North Tank Farm, Tank W-11, and Gunite and Associated Tanks-Treatability Study \\ (ORNL/ER-382)}

Recommended by:

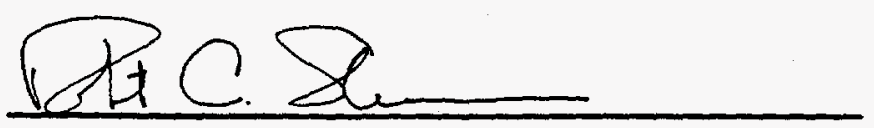

R. C. Sleeman, Director

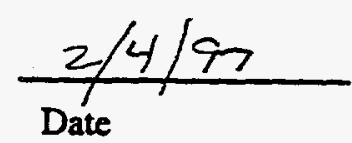

DOE ORO Environmental Restoration

Division

Approved by:

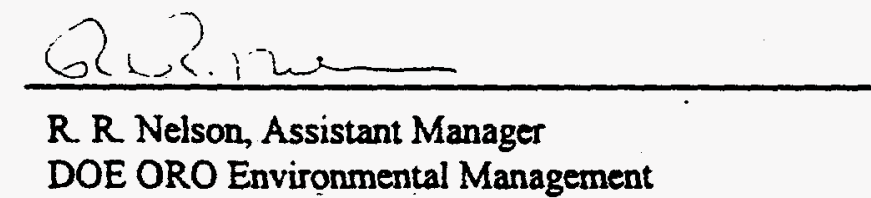

$-210197$

Date

DOE ORO Environmental Management 



\section{PREFACE}

This document was prepared under Work Breakdown Structure 1.4.12.6.1.01.41.12.02.11 (Activity Data Sheet 3301, Waste Area Grouping 1, Gunite and Associated Tanks Operable Unit). This document provides the Environmental Restoration Program with the nuclear and non-nuclear hazard categorization for the Oak Ridge National Laboratory North Tank Farm (Building 3023) and the Gunite and Associated Tanks Treatability Study. The results of this report provide essential input for determining the need to apply the nuclear facility requirements from DOE Orders 5480.21, 5480.22, and 5480.23; 10CFR830.120; and other requirements. 



\section{CONTENTS}

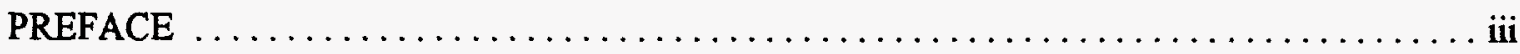

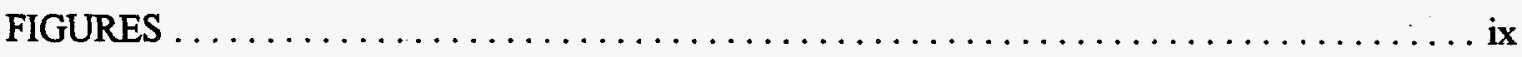

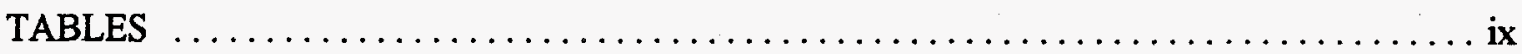

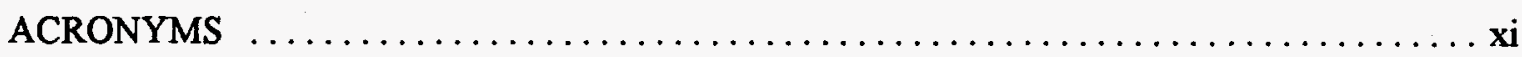

EXECUTIVE SUMMARY $\ldots \ldots \ldots \ldots \ldots \ldots \ldots \ldots \ldots \ldots \ldots \ldots \ldots \ldots \ldots \ldots \ldots \ldots \ldots \ldots \ldots$

E.1 NORTH TANK FARM BACKGROUND $\ldots \ldots \ldots \ldots \ldots \ldots \ldots \ldots \ldots \ldots \ldots \ldots \ldots \ldots$

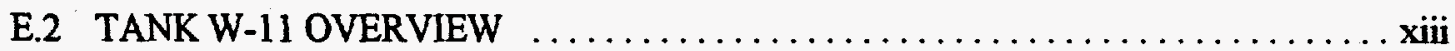

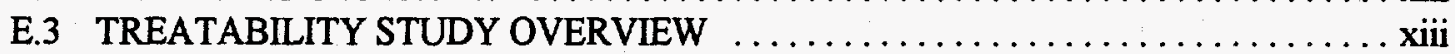

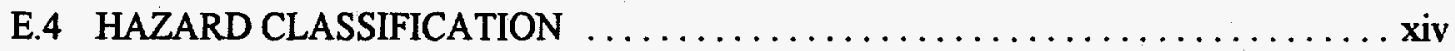

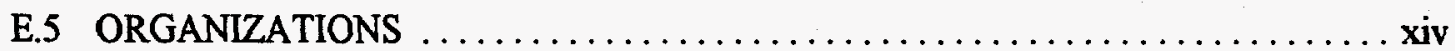

E.6 SAFETY ANALYSIS CONCLUSIONS $\ldots \ldots \ldots \ldots \ldots \ldots \ldots \ldots \ldots \ldots \ldots \ldots \ldots \ldots \ldots \ldots$

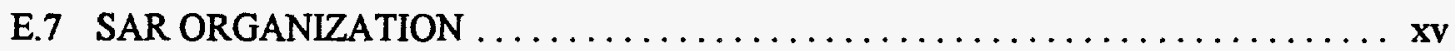

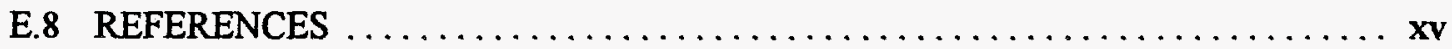

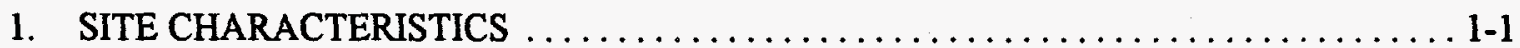

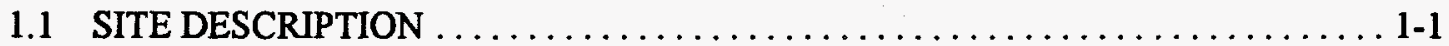

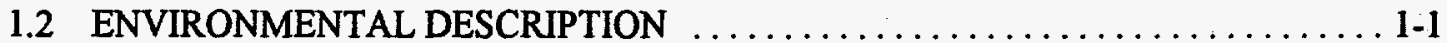

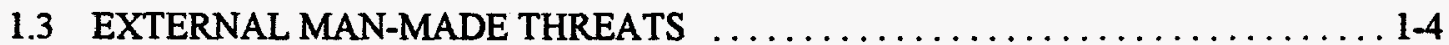

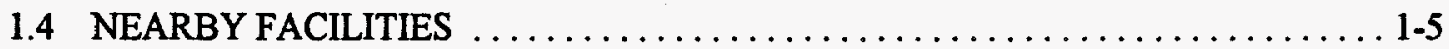

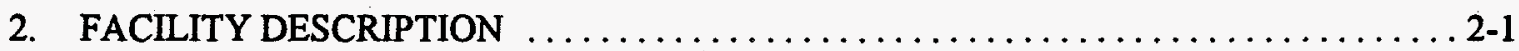

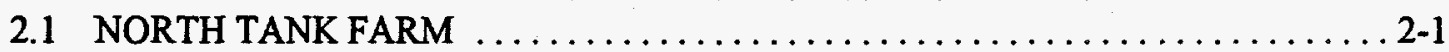

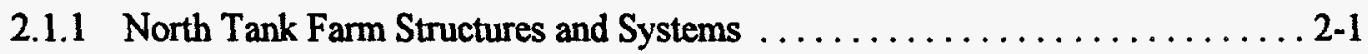

2.1.2 North Tank Farm Activities and Processes $\ldots \ldots \ldots \ldots \ldots \ldots \ldots \ldots \ldots . . \ldots \ldots$

2.1.3 North Tank Farm Utility Support Systems $\ldots \ldots \ldots \ldots \ldots \ldots \ldots \ldots . \ldots \ldots . \ldots \ldots$

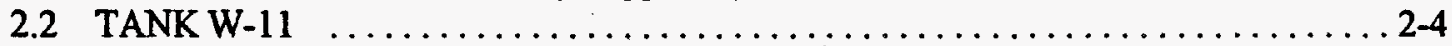

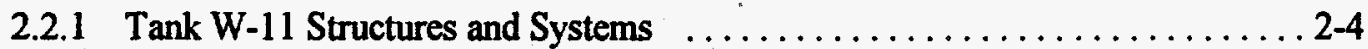

2.2.2 Tank W-11 Activities and Processes .................... 2.5

2.3 GUNITE AND ASSOCIATED TANKS - TREATABILITY STUDY $\ldots \ldots \ldots \ldots 2-5$

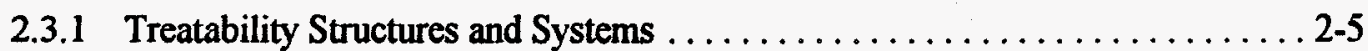

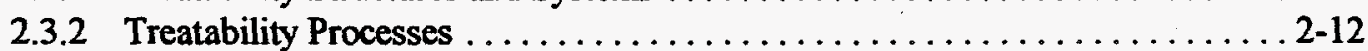

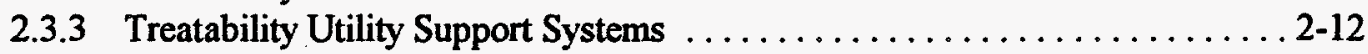

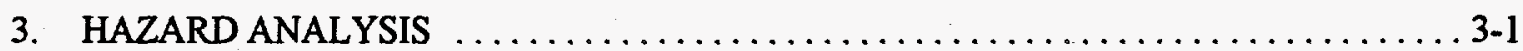

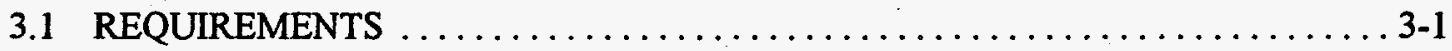

3.2 HAZARD IDENTIFICATION AND ANALYSIS METHODOLOGY $\ldots \ldots \ldots \ldots$ 3-1

3.2.1 Hazard Identification and Preliminary Facility Hazard

Classification Methodology . . . . . . . . . . . . . . . . . . 3-1

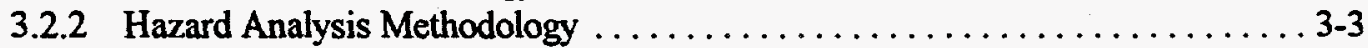

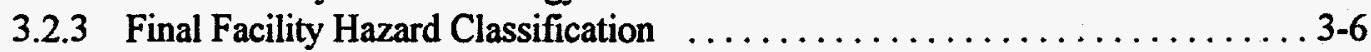

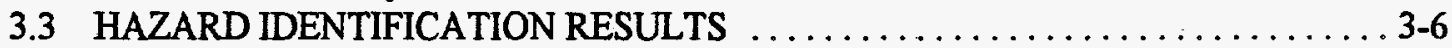




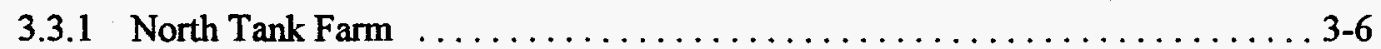

3.3 .2 Tank $W-11 \ldots \ldots \ldots \ldots \ldots \ldots \ldots \ldots \ldots \ldots \ldots \ldots \ldots \ldots \ldots \ldots \ldots \ldots \ldots .17$

3.3.3 Gunite and Associated Tanks: Treatability Study . . . . . . . . . . . 3-19

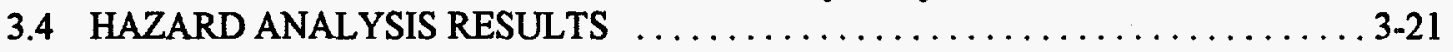

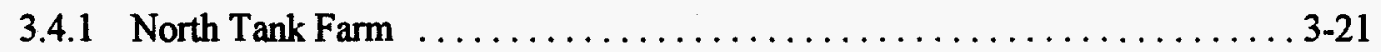

3.4 .2 Tank $W-11 \ldots \ldots \ldots \ldots \ldots \ldots \ldots \ldots \ldots \ldots \ldots \ldots \ldots \ldots \ldots \ldots \ldots \ldots \ldots \ldots \ldots .23$

3.4.3 Gunite and Associated Tanks: Treatability Study . . . . . . . . . . 3-23

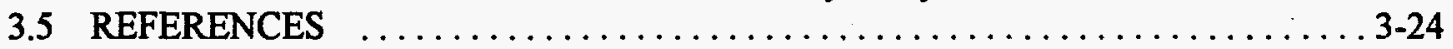

4. PREVENTION OF INADVERTENT CRITICALITY $\ldots \ldots \ldots \ldots \ldots \ldots \ldots \ldots \ldots \ldots . .$.

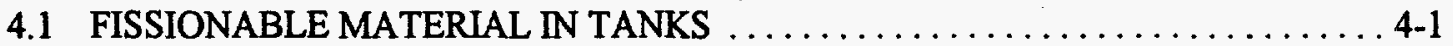

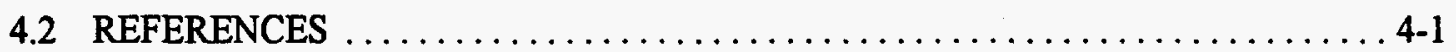

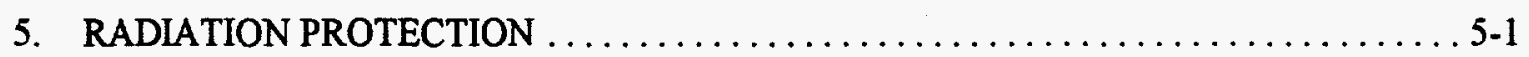

5.1 RADIATION PROTECTION PROGRAM $\ldots \ldots \ldots \ldots \ldots \ldots \ldots \ldots \ldots \ldots \ldots \ldots \ldots \ldots \ldots \ldots$

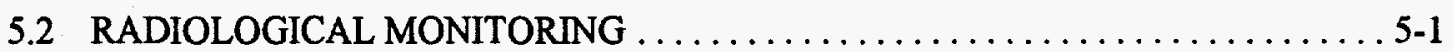

5.3 RADIOLOGICAL PROTECTION INSTRUMENTATION $\ldots \ldots \ldots \ldots \ldots \ldots .5-1$

5.4 OCCUPATIONAL RADIATION EXPOSURES FOR TREATABILITY STUDY . . 5-2

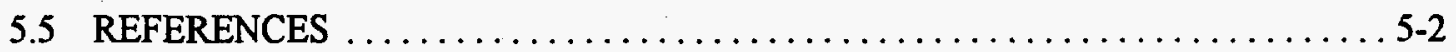

6. INITIAL TESTING AND MAINTENANCE $\ldots \ldots \ldots \ldots \ldots \ldots \ldots \ldots \ldots \ldots \ldots \ldots$

6.1 TREATABILITY STUDY INITIAL TESTING $\ldots \ldots \ldots \ldots \ldots \ldots \ldots \ldots \ldots \ldots .6 .1$

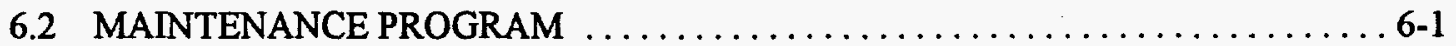

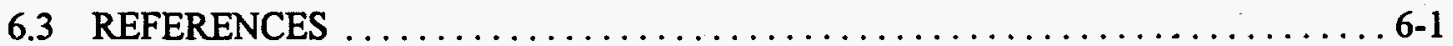

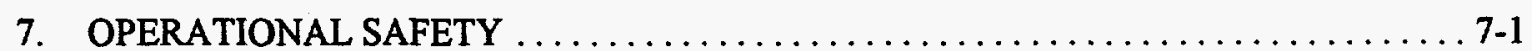

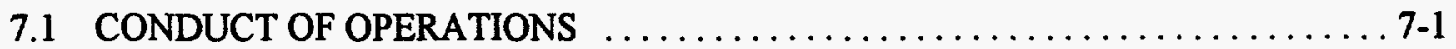

7.1.1 North Tank Farm and Tank W-11 ................... $7-2$

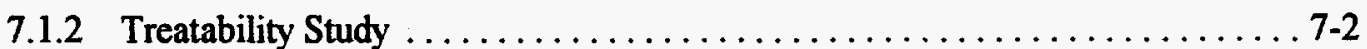

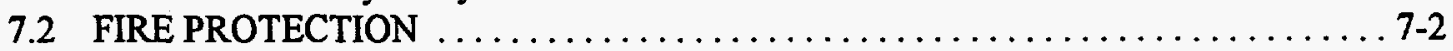

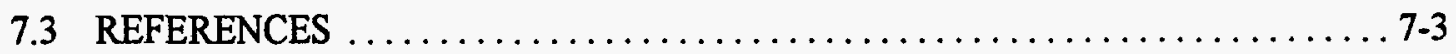

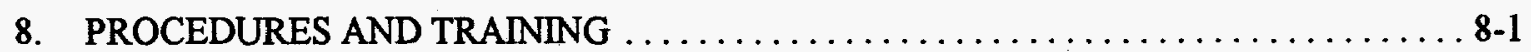

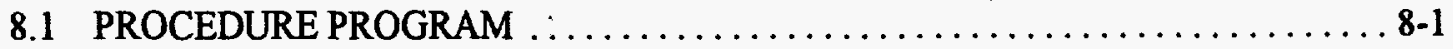

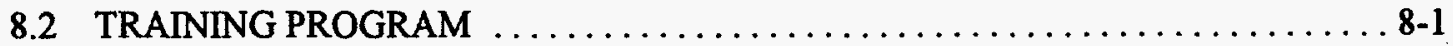

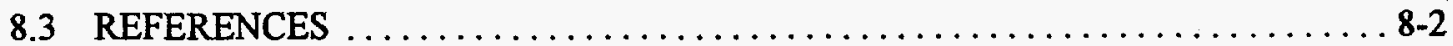

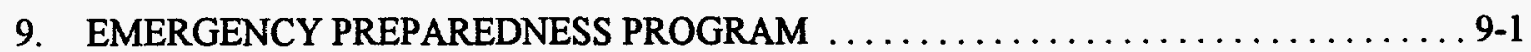

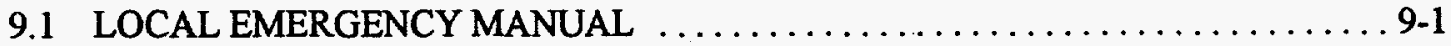

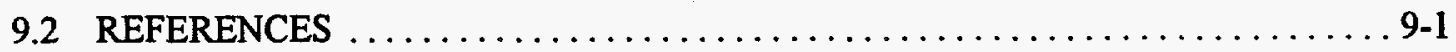

10. MANAGEMENT, ORGANIZATION, AND INSTITUTIONAL SAFETY PROVISIONS 10-1

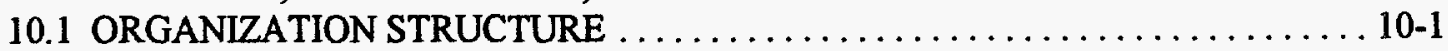

10.2 CONFIGURATION AND DOCUMENT CONTROL $\ldots \ldots \ldots \ldots \ldots \ldots \ldots \ldots$ 10-1

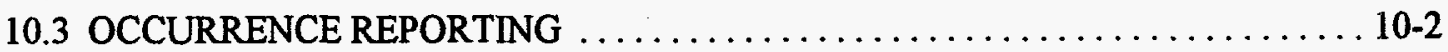

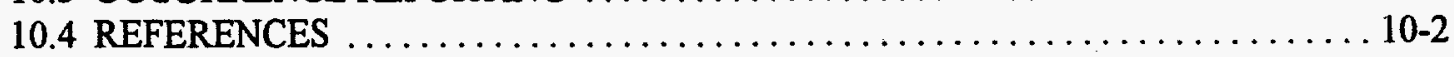


APPENDIX A Hazard Identification Tables For The North Tank Farm $\ldots \ldots \ldots \ldots \ldots \ldots$ A-1

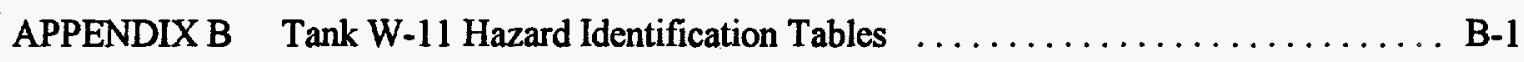

APPENDIX C Treatability Study Hazard Identification Tables $\ldots \ldots \ldots \ldots \ldots \ldots \ldots$ C-1

APPENDIX D North Tank Farm Preliminary Hazards Analysis .............. D-1

APPENDIX E Treatability Study Preliminary Hazards Analysis $\ldots \ldots \ldots \ldots \ldots \ldots \ldots$ E-1 



\section{FIGURES}

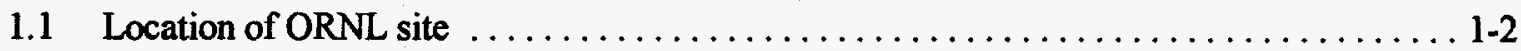

1.2 Location of the North Tank Farm at ORNL . . . . . . . . . . . . . . . . . . . 1-3

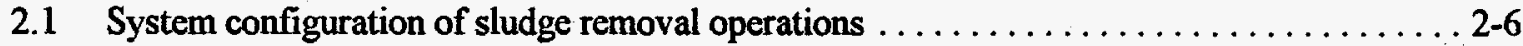

2.2 In-tank equipment configuration for sludge removal using the MLDUA $\ldots \ldots \ldots \ldots \ldots 2-7$

2.3 In-tank equipment configuration for sludge removal using the remote operated vehicle $\ldots .2-8$

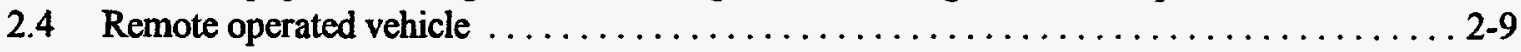

3.1 Preliminary nuclear facility hazard categorization logic process $\ldots \ldots \ldots \ldots \ldots \ldots .4$

\section{TABLES}

E.1 Safety Analysis Report content requirements and "road map" .............. xv

3.1 Non-radiological hazard screening health effects criteria $\ldots \ldots \ldots \ldots \ldots \ldots \ldots \ldots \ldots \ldots \ldots$

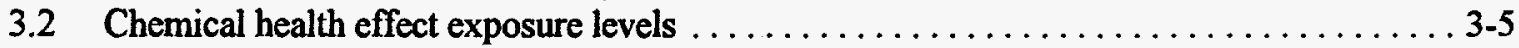

3.3 Preliminary hazards identification results for the North Tank Farm tanks . . . . . . . 3-7

3.4 Determination of ${ }^{235} \mathrm{U}$ fissionable equivalent mass in the NTF facility tanks $\ldots \ldots \ldots \ldots 3-8$

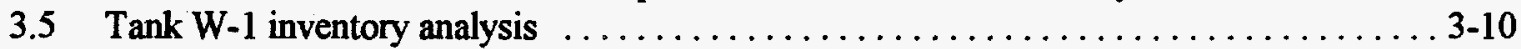

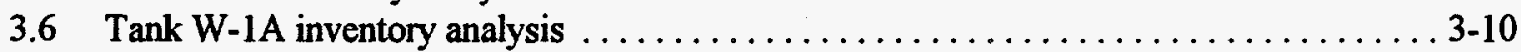

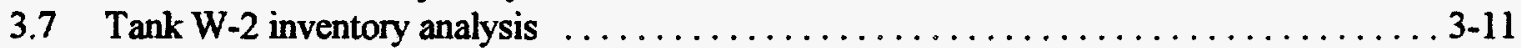

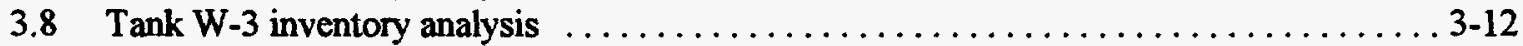

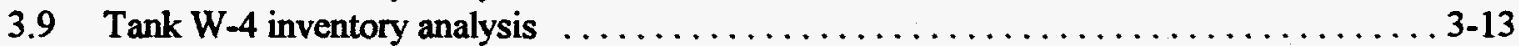

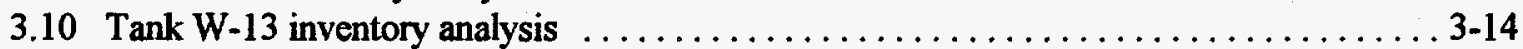

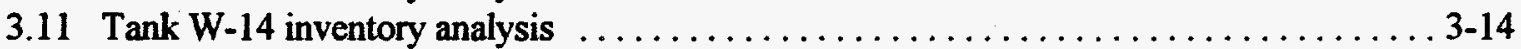

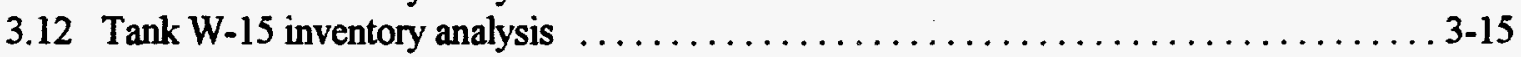

3.13 Determination of ${ }^{235} \mathrm{U}$ fissionable equivalent mass in Tank $\mathrm{W}-11 \ldots \ldots \ldots \ldots \ldots . .3-15$

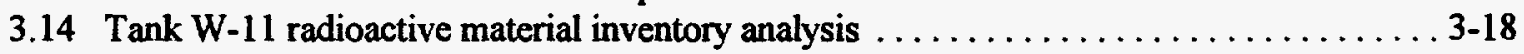

3.15 Treatability Study hazards identification summary $\ldots \ldots \ldots \ldots \ldots \ldots \ldots \ldots \ldots . \ldots \ldots$

3.16 Evaluation of fissionable materials associated with the Treatability Study . . . . . . 3-20

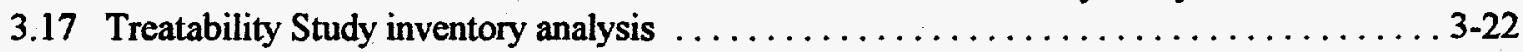

5.1 Estimate of exposure rates for Tanks W-3/W-4 transfers $\ldots \ldots \ldots \ldots \ldots \ldots \ldots \ldots$ 



\section{ACRONYMS}

\begin{tabular}{|c|c|}
\hline ALARA & As Low As Reasonably Achievable \\
\hline ANSI & American National Standards Institute \\
\hline ARF & Airborne Release Fraction \\
\hline ASME & American Society of Mechanical Engineers \\
\hline CDS & Cutting/Dislodging System \\
\hline CERCLA & Comprehensive Environmental Response, Compensation, and Liability Act \\
\hline $\mathrm{CI}$ & Configuration Item \\
\hline CSEE & Confined Sluicing End Effector \\
\hline DOE & U. S. Department of Energy \\
\hline DOP & Dioctylphthlate \\
\hline Energy Research & Lockheed Martin Energy Research, Inc. \\
\hline Energy Systems & Lockheed Martin Energy Systems, Inc. \\
\hline EPA & U. S. Environmental Protection Agency \\
\hline ER & Environmental Restoration \\
\hline $\begin{array}{l}\text { GAAT-TS } \\
\text { gpm }\end{array}$ & $\begin{array}{l}\text { Gunite and Associated Tanks - Treatability Study } \\
\text { gallons per minute }\end{array}$ \\
\hline HEPA & High Efficiency Particulate Air \\
\hline HMS & Hose Management System \\
\hline HVAC & Heating, Ventilating, and Air Conditioning \\
\hline IDLH & Immediately Dangerous to Life and Health \\
\hline IEEE & Institute of Electrical and Electronics Engineers \\
\hline ILLLW & Inactive Liquid Low-Level Waste (tanks) \\
\hline ISC & Industrial Source Code \\
\hline ITO & Incentive Task Order \\
\hline LLLW & Liquid Low-Level Waste \\
\hline MDS & Mobile Deployment System \\
\hline MLDUA & Modified Light Duty Utility Arm \\
\hline NFPA & National Fire Protection Association \\
\hline NIST & National Institute of Standards and Technology \\
\hline NTF & North Tank Farm \\
\hline ORNL & Oak Ridge National Laboratory \\
\hline OSHA & Occupational Safety and Health Administration \\
\hline PCM & Personnel Contamination Monitor \\
\hline PHA & Preliminary Hazards Analysis \\
\hline ROV & Remotely Operated Vehicle \\
\hline RQ & Reportable Quantity \\
\hline STF & South Tank Farm \\
\hline Treatability Study & Gunite and Associated Tanks - Treatability Study \\
\hline TQ & Threshold Quantity \\
\hline Valley & Tennessee Valley \\
\hline WD\&C & Waste Dislodging and Conveyance \\
\hline WOCC & Waste Operations Control Center \\
\hline
\end{tabular}





\section{EXECUTIVE SUMMARY}

\section{E.1 NORTH TANK FARM BACKGROUND}

The North Tank Farm (NTF) tanks consist of eight underground storage tanks (Tanks W-1, W-1A, W-2, W-3, W-4, W-13, W-14, and W-15). Four of the tanks (W-1, W-2, W-3, and W-4) were constructed using an in-place gunite construction process. An aggregate-free concrete (gunite) was sprayed in layers onto rebar skeletons to form the tanks in place. The other four tanks (W-1A, W-13, W-14, and W-15) are constructed of stainless steel. Built in the 1940s, the underground storage tanks have since been removed from service because of age and changes in liquid waste system needs and requirements. Tanks W-1 and W-2 contain between several hundred and several thousand gallons of liquid low-level waste (LLLW). Tanks W-1A, W-13, W-14, and W-15 have all been emptied. Tanks W-3 and W-4 contain tens of thousands of gallons of LLLW and sludges. Tanks W-1A, W-3, and W-4 require periodic pumping to the active LLLW System for removal of tank inleakage.

\section{E.2 TANK W-11 OVERVIEW}

Tank W-11 is a 1500-gal gunite tank located in the Bethel Valley South Tank Farm (STF). The underground tank was constructed in 1943 to serve as a waste collection and monitoring tank for research laboratories in Building 3550 . Tank W-11 has been removed from service because of age and changes in liquid waste system needs and requirements. Tank W-11 contains several hundred gallons of LLLW.

\section{E.3 TREATABILITY STUDY OVERVIEW}

The Gunite and Associated Tanks (GAAT) Treatability Study involves the demonstration of sludge removal techniques and equipment for use in other waste storage tanks throughout the Department of Energy (DOE) complex. Sludges in Tanks W-3 and W-4 in the NTF will be the subject of the study. Sludges will be dislodged and transferred between tanks. A technique known as confined sluicing, which uses a high-pressure, low-volume water jet integrated with a jet pump, will be demonstrated and thoroughly evaluated. Two deployment options are considered in the Treatability Study for the confined sluicing. The first is a Modified Light Duty Utility Arm (MLDUA), which is a remotely controlled robotic arm that can be used to position and manipulate the sluicing equipment The second is a remotely operated vehicle. The tracked vehicle, equipped with a plow type blade is used to position and manipulate the confined sluicing equipment and to move sludge around the tank with the blade. The Treatability Study will be used to evaluate performance, provide design information, and to estimate costs in sufficient detail to support future remedy selection processes.

After the MLDUA, tracked vehicle and confined sluicing equipment have been tested for mobilizing the sludges and transferring the sludges between the tanks, the sludges will be removed from the W-3 and W-4 tanks and ultimately transferred to the Melton Valley Storage Tanks in Building 7830. The sludges will be pumped to one of two approximately 500-gal conditioning tanks located in or close to the NTF. The sludges will be transferred to the Melton Valley Storage Tanks via the 1+-mile long intervalley transfer line that is part of the ORNL LLLW System. Before being transferred through the intervalley transfer line, the sludges must be conditioned to ensure they do not inadvertently plug the 
transfer line and to ensure they meet the appropriate requirements for the ORNL LLLW System Waste Acceptance Criteria.

\section{E.4 HAZARD CLASSIFICATION}

The hazards associated with the NTF, Tank W-11, and the Treatability Study are identified in hazard identification table in Appendixes A, B, and C. The identified hazards were compared to screening values from $E S / C S E T-2 / R 2^{1}$ to eliminate from further evaluation hazards that were considered insignificant, routine, or standard industrial. The remaining sources of hazardous material or energy were used to determine a nuclear and a non-nuclear facility hazard classification for the NTF, Tank W-11, and the Treatability Study. The facility hazard classification is documented in Chap. 3. Tank W-11 was determined to have a nuclear facility classification of "Industrial" and a non-nuclear facility classification of "Industrial." The NTF and the Treatability Study were initially determined to have a preliminary nuclear facility classifications of "Category 3 and non-nuclear facility classifications of "Industrial". Final facility hazard categorization which accounted for the hazardous material physical characteristics and the type and magnitude of energy sources available for dispersal of the hazardous materials resulted in nuclear facility hazard classifications of "Radiological" for both the NTF and the Treatability Study.

\section{E.5 ORGANIZATIONS}

The NTF and the Treatability Study are the responsibility of Lockheed Martin Energy Systems, Inc. (Energy Systems) Environmental Restoration (ER) Program. The tanks, equipment, and facilities are physically located on the Oak Ridge National Laboratory (ORNL) site. The ORNL site is managed by Lockheed Martin Energy Research, Inc. A draft Memorandum of Agreement outlines the procedures, accountable parties, roles, and rèsponsibilities associated with interfaces between Energy Research and Energy Systems ER. Energy Systems ER is responsible for identification, remediation, and surveillance of the low-level radioactive waste tank systems at ORNL and for coordinating the prioritization of environmental restoration tasks at ORNL with appropriate regulatory agencies. ORNL is responsible for providing environmental regulatory guidance, interpretation, and oversight, for establishing safety and health requirements, for providing health physicist support and oversight, for providing technical support and oversight in the areas of safety documentation upgrade, and for providing quality assurance support and inspection services.

System Safety Engineering of Energy Systems is responsible for coordination of the safety documentation. Science Applications International Corporation, a subcontract consultant, prepared this SAR with guidance from System Safety Engineering and ER project personnel and facility managers.

\section{E.6 SAFETY ANALYSIS CONCLUSIONS}

The hazards identified for the NTF, Tank W-11, and the Treatability Study were analyzed in the preliminary hazards analyses (PHA) included as Appendices D and E. The PHA identifies potential accident scenarios and qualitatively estimates the consequences. Because of the limited quantities of materials present in the tanks and the types of energy sources that may result in release of the materials, none of the accidents identified are anticipated to result in significant adverse health effects to on-site or off-site personnel. 


\section{E.7 SAR ORGANIZATION}

The nuclear safety classifications for the NTF and Tank W-11 surveillance and maintenance activities and for the Treatability Study were all determined to be Radiological. Radiological facilities, by definition, are not required to have SARs by DOE Order $5480.23 .^{2}$ The format and content of this document, however, is based on the minimum level of detail for a simple Hazard Category 3 facility as outlined on Page 17 of DOE-STD-3009-94. ${ }^{3}$ The minimum content guidance and where, in this SAR, the information is located is presented in Table E.1.

Table E.1. Safety Analysis Report content requirements and "road map"

\section{Minimum Content Requirements for Category 3 SAR} (DOE-STD-3009-94)

Statement of the facility mission, life cycle, hazards, and summary of the safety analysis results

Brief description of the standards and requirements that govern the operations

Brief description of facility siting to identify location and boundaries

Sufficient facility description to provide an understanding of facility processes, structures, systems, and components

Basic hazard analysis (traditional accident analysis is not normally performed) sufficient to understand hazards posed to workers and the environment

Derivation of TSRs to limit inventories of hazardous materials and to protect workers from unique hazards

Programmatic safety descriptions to address site specific, safety management programs in relation to hazards identified
Location of Information in the Safety Analysis Report

Executive Summary

Included in each SAR chapter

SAR Chapter 1

SAR Chapter 2

\section{SAR Chapter 3}

Because no facilities in this SAR were determined to be "Nuclear" facilities, no TSRs are required as defined in DOE Order $5480.22^{4}$.

Applicable Safety Management Programs are addressed in the following SAR Chapters:
4. Prevention of Inadvertent Criticality
5. Radiation Protection Program
6. Initial Testing and Maintenance
7. Operational Safety
8. Procedures and Training
9. Emergency Preparedness Program
10. Management, Organization, and Institutional Safety Provisions

\section{E.8 REFERENCES}

1. ES/CSET-2/R2, Safety Analysis Report Update Program Hazard Identification and Facility Classification Application Guide, Lockheed Martin Energy Systems, Inc., Oak Ridge, Tennessee, December 1995. 
2. DOE Order 5480.23, Nuclear Safety Analysis Reports, U.S. Department of Energy, Washington, D.C., April 30, 1992.

3. DOE-STD-3009-94, Preparation Guide for U.S. Department of Energy Non-reactor Nuclear Facility Safety Analysis Reports, U.S. Department of Energy, Washington, D.C., July 1994.

4. DOE Order 5480.22, Technical Safety Requirements, U.S. Department of Energy, Washington, D.C. 


\section{SITE CHARACTERISTICS}

\subsection{SITE DESCRIPTION}

The Oak Ridge National Laboratory (ORNL) is a government facility managed by Energy Research for the U.S. Department of Energy (DOE). ORNL is located in Bethel and Melton Valleys, approximately 8 miles southwest of the population center of the city of Oak Ridge, Tennessee. Figure 1.1 is a map indicating the location of the ORNL site on Bethel Valley Road in Roane County.

The North Tank Farm (NTF) is located in the main laboratory area in Bethel Valley. The NTF consists of eight underground radioactive liquid waste collection tanks, all inactive (i.e., they are no longer receiving radioactive waste from generating facilities). Two of the tanks, W-3 and W-4, will be used to test and demonstrate sludge removal technologies in the Gunite and Associated Tanks Treatability Study (GAAT-TS) or the Treatability Study project. Figure 1.2 shows the location of the NTF and Tank W-11 within the ORNL site. The NTF is at the northeast corner of Third Street and Central Avenue. Tank W-11 is approximately $140 \mathrm{ft}$ south of Central Avenue and approximately 250 $\mathrm{ft}$ east of Third Street.

Two public roads traverse the Oak Ridge Reservation (ORR) and provide access to ORNL. State Highway 95 runs north-south approximately 1 mile west of the main ORNL complex. Bethel Valley Road runs east-west along the northern edge of the ORNL site. Both of these roads can be shut down, if needed, in the event of a serious accident at ORNL. Access to the NTF is available from Bethel Valley Road via First Street to Central Avenue. All access roads onto the ORNL site (e.g., First Street) are closed to the public. Manned guard posts and unmanned physical barriers control access except during shift changes at ORNL (typically 6 a.m. - 9 a.m. and 4 p.m. -6 p.m.). Access may be controlled during these hours as needed. Access to the main laboratory complex (where the tanks are located) is controlled by manned guardhouses, badge readers, and turn gates.

The NTF is approximately $1000 \mathrm{ft}$ south of Bethel Valley Road. The closest DOE boundary point is approximately 2.25 miles to the west-southwest at the Clinch River.

\subsection{ENVIRONMENTAL DESCRIPTION}

ORNL is located in the Tennessee Valley (Valley), a broad funnel-shaped valley in the eastern part of Tennessee. The Valley, which contains the Tennessee River and its tributaries, is bordered to the northwest by the Cumberland Plateau with an average elevation of $2000 \mathrm{ft}$ and to the southeast by the Great Smoky Mountains with peaks that rise as high as $6000 \mathrm{ft}$.

The average daily temperatures (measured at $\mathrm{ORNL}$ ) vary from $37^{\circ} \mathrm{F}$ in January to $77^{\circ} \mathrm{F}$ in July. The average annual precipitation is $54.76 \mathrm{in}$., with almost even monthly distribution. An average of at least one thunderstorm per month occurs throughout the year. Hail generally occurs in the months of February through August and only about 5 days every 2 years. Snow can be expected from late fall through early spring. The mean snowfall each season is about 10.2 in., and the maximum recorded snowfall in one season is $41.4 \mathrm{in}$. 
1-2

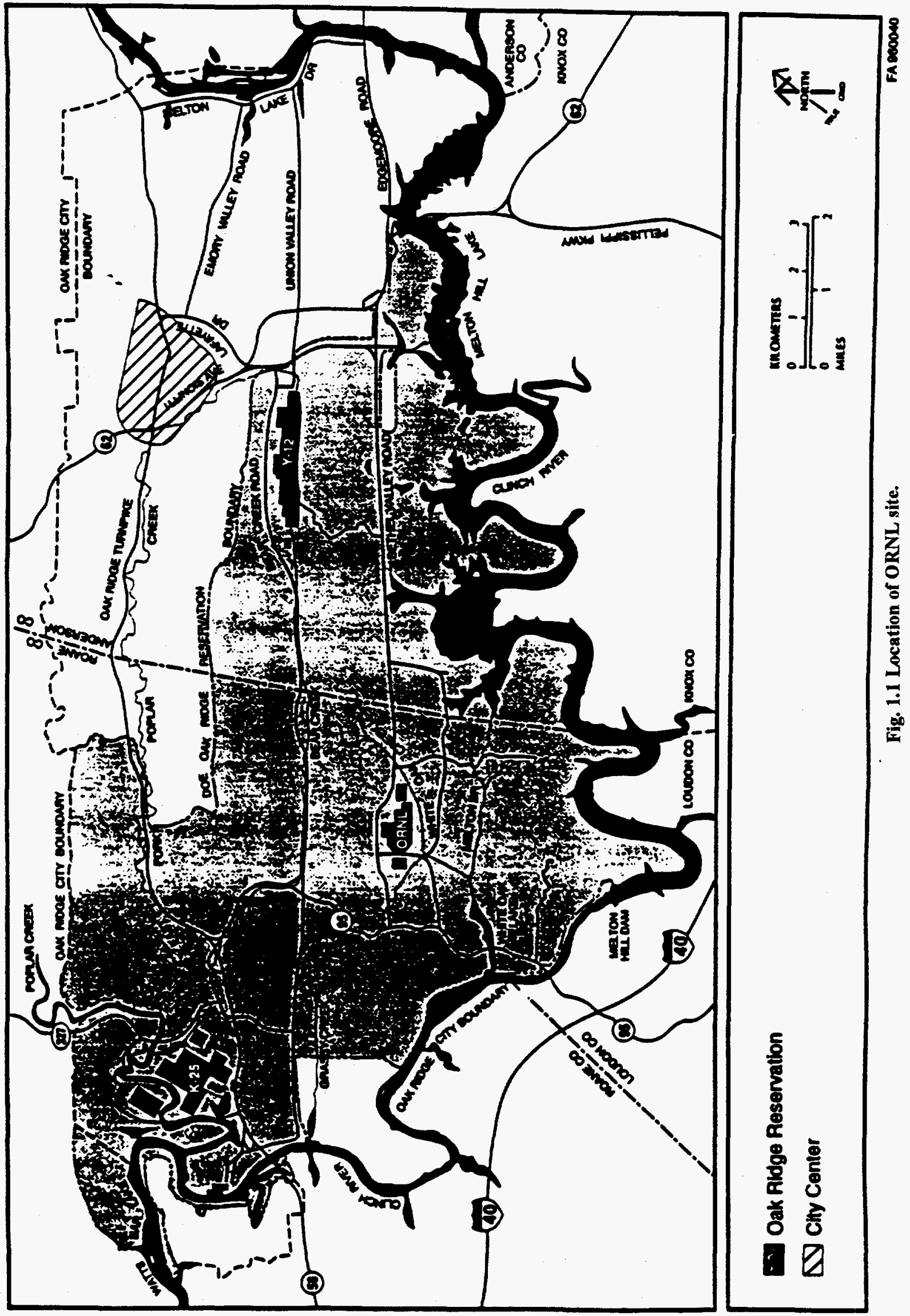




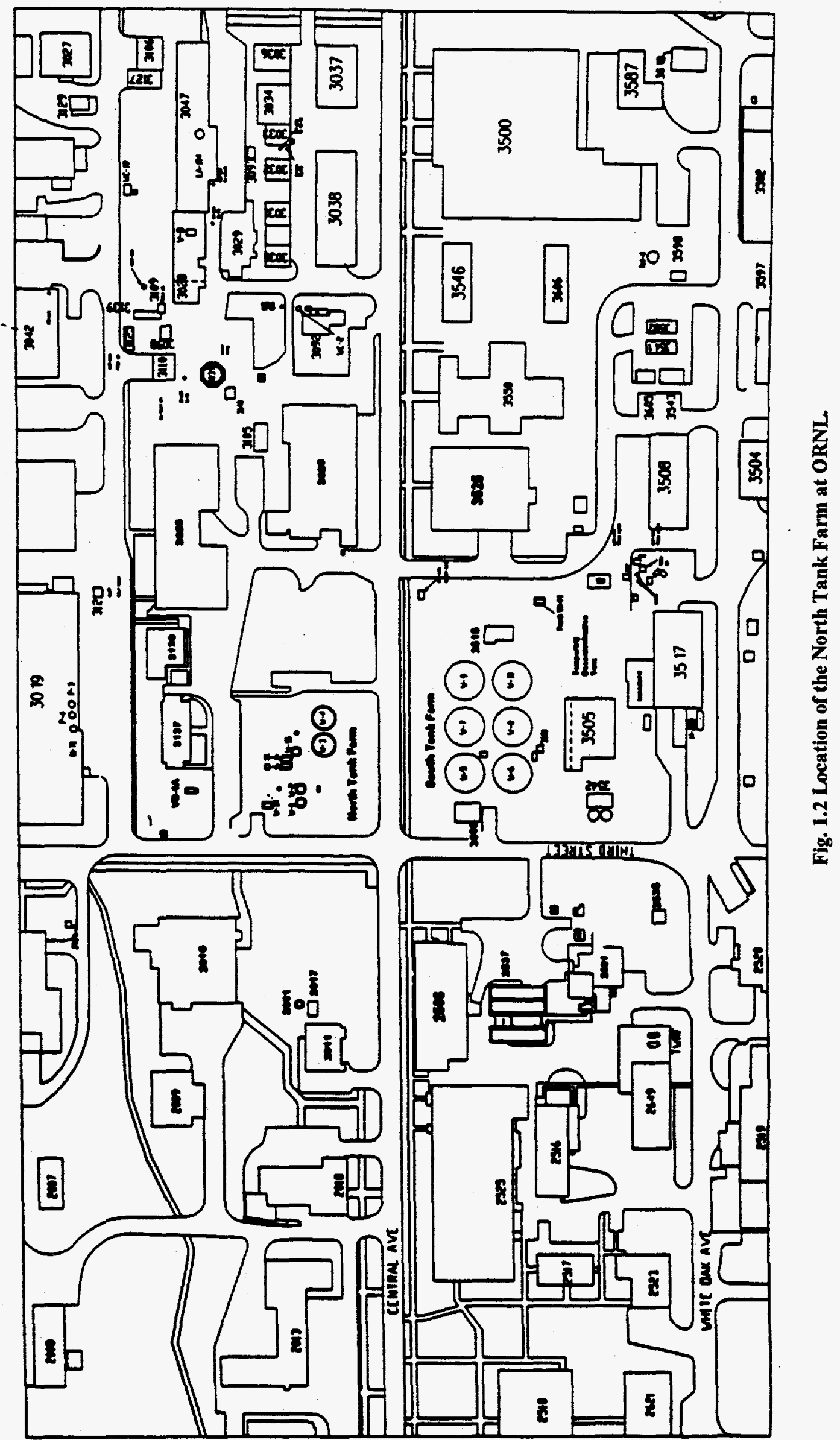


The wind direction above the ridge tops and within the Valley at ORNL tends to be aligned with the orientation of the Valley. The prevailing wind is from the southwest with a secondary maximum from the northeast during the winter, spring, and summer months. This situation is reversed in the fall, with the prevailing northeast wind. Wind speeds measured in the ORNL Bethel Valley area are:

$\begin{array}{cc}\text { Wind Speed (mph) } & \text { Annual Frequency of Occurrence (\%) } \\ \text { Calm } & 21 \\ 1-3 & 29 \\ 4-7 & 25 \\ 8-12 & 15 \\ 13-18 & 5 \\ 19-24 & 1 \\ 25+ & <1 \\ \text { Unknown } & 3\end{array}$

Dispersion is related closely to atmospheric stability. The vertical temperature gradients were used to define stability classes in accordance with the requirements of Regulatory Guide 1.23 (Safety Guide 23) at the ORNL Bethel Valley site and the ORNL Tower Shielding Facility. The frequencies of occurrence of these stability classes are:

\begin{tabular}{lc}
\multicolumn{1}{c}{ Stability Class } & Frequency of Occurrence (\%) \\
A - Extremely Unstable & 24 \\
B - Moderately Unstable & 2 \\
C - Slightly Unstable & 2 \\
D - Neutral & 16 \\
E - Slightly Stable & 23 \\
F - Moderately Stable & 16 \\
G - Extremely Stable & 17
\end{tabular}

Bethel Valley is in the White Oak Creek drainage basin. Surface water flow in White Oak Creek is augmented by treated process wastewater, treated sanitary sewage effluent, and cooling water discharges from various ORNL facilities. White Oak Creek is impounded by White Oak Dam about 0.5 mile above the confluence of White Oak Creek and the Clinch River. The impoundment, White Oak Lake, is used as a settling basin for waste effluent discharged from ORNL facilities.

\subsection{EXTERNAL MAN-MADE THREATS}

The following external man-made threats are considered as potential initiators in Chap. 3, Hazard Analysis.

- Dam failure - there are several dams controlling flow on the White Oak Creek, the Clinch River, and the Tennessee River

- Aircraft crash 
- Transportation and construction accidents

- Explosions - from natural gas pipelines or adjacent facilities

\subsection{NEARBY FACILITIES}

The NTF is located in the main laboratory complex of ORNL in Bethel Valley. As such nearly all laboratory facilities are within approximately $2000 \mathrm{ft}$ of the NTF. The facilities that are located in the immediate area of the NTF are listed below:

- South Tank Farm, LLLW System valve boxes VB-1 and VB-2, and Tank W-11 are located approximately $140 \mathrm{ft}$ south of the NTF on the opposite side of Central Avenue

- Building 3515 is located approximately $213 \mathrm{ft}$ southeast of Tank W-4 and $39 \mathrm{ft}$ northwest of Tank W-11 just east of the South Tank Farm

- Building 3525 is located approximately $268 \mathrm{ft}$ east-southeast of Tank W-4 and $87 \mathrm{ft}$ east of Tank W-11

- Building 3026 is located approximately $208 \mathrm{ft}$ east of Tank W-4 and $325 \mathrm{ft}$ north-northeast of Tank W-11

- Building 3025 is located approximately $172 \mathrm{ft}$ north east of Tank W-4 and $394 \mathrm{ft}$ north of Tank W-11

- Building 3137 is located approximately $105 \mathrm{ft}$ north-northeast of Tank W-1A and $460 \mathrm{ft}$ northnorthwest of Tank W-11

- Building 3130 is located approximately $203 \mathrm{ft}$ northeast of Tank W-1A and $447 \mathrm{ft}$ north of Tank W-11, between Buildings 3137 and 3025

- LLLW System valve box VB-1A is located approximately $84 \mathrm{ft}$ north of Tank W-1A and $493 \mathrm{ft}$ northwest of Tank W-11, near the west end of Building 3137

- Building 2010 (the cafeteria) is located approximately $146 \mathrm{ft}$ west-northwest of Tank W-1A across Third Street and $559 \mathrm{ft}$ northwest of Tank W-11

- Buildings 2011,2017 , and 2061 are located approximately $247 \mathrm{ft}$ west of Tank W-1 and $584 \mathrm{ft}$ west-northwest of Tank W-11

- Building 2506 is located approximately $224 \mathrm{ft}$ southwest of Tank W-1 and $448 \mathrm{ft}$ west-northwest of Tank W-11 on the south side of Central Avenue

- The evaporator facility complex (Buildings $2531,2532,2533,2534,2535$, and 2537) is located approximately $327 \mathrm{ft}$ southwest of Tank W-1 and $396 \mathrm{ft}$ west of Tank W-11 on the west side of Third Street 



\section{FACILITY DESCRIPTION}

\subsection{NORTH TANK FARM}

The NTF consists of eight underground storage tanks.

\subsubsection{North Tank Farm Structures and Systems}

Tanks W-1, W-1 A, W-2, W-3, W-4, W-13, W-14, and W-15 comprise the inactive NTF tanks. Only tanks W-3 and W-4 are included in the scope of the treatability study. The remaining tanks will be closed using maintenance actions.

\subsubsection{Tank W-1}

Tank W-1 was put into service in 1943 and continued in service until the 1960s. The tank was used to store waste from Building 3019 which consisted of a highly radioactive metal and chemical waste. When the tank was sampled in 1995, it contained approximately 2926 gal of liquid.

Tank W-1 is constructed of gunite (reinforced concrete). The tank has a nominal capacity of 4800 gal. Tank W-1 is a vertical cylindrical tank with a $12 \mathrm{ft}$ inner diameter and a wall height of $8 \mathrm{ft}$. The tank is covered with $6 \mathrm{ft}$ of soil, and the sides are surrounded by crushed rock. The tank has an associated dry well. There is no ventilation system provided on Tank W-1. Level detection is provided by a conductivity probe

\subsubsection{Tank W-1A}

Tank W-1A was put into service in 1951. The tank received wastes from a radiochemical processing facility (Building 3019) and an analytical laboratory (Building 2026). Tank W-1A was removed from service in 1986 because it was collecting inleakage (mainly rainwater). The tank is emptied periodically to the active LLLW System, as needed. It collected an average of $1750 \mathrm{gal} / \mathrm{month}$ during 1992.

Tank W-1A is constructed of stainless steel. The tank is a horizontal, cylindrical tank that is $7 \mathrm{ft}$ $6 \mathrm{in}$. in diameter and $13 \mathrm{ft} 8 \mathrm{in}$. long. The tank is covered by approximately $5 \mathrm{ft}$ of soil. It is vented through a high efficiency particulate air (HEPA) filter. Level detection is provided by a pneumatic gauge.

\subsubsection{Tank W-2}

Tank W-2 was put in service in 1943 and continued in service until the 1960s. Tank W-2 was used to store waste from a radiochemical processing facility (Building 3019). This tank was an overflow for Tank W-1. The tank was shut down because of suspected leakage. When Tank W-2 was sampled in 1994, it contained approximately $2000 \mathrm{gal}$.

Tank W-2 is constructed of gunite (reinforced concrete). The tank has a nominal capacity of 4800 gal. Tank W-2 is a vertical cylindrical tank with a $12 \mathrm{ft}$ inner diameter and a wall height of $8 \mathrm{ft}$. The tank is covered with $6 \mathrm{ft}$ of soil, and the sides are surrounded by crushed rock. The tank has an associated dry well. There is no ventilation system provided on Tank W-2. Level detection is provided by a conductivity probe. 


\subsubsection{Tank W-3}

Tank W-3 is a 42,500-gal underground, domed, gunite (reinforced concrete) tank located in the NTF. The tank has an inside diameter of $25 \mathrm{ft}$, a vertical sidewall height of $12 \mathrm{ft}$, and an additional dome height of $3.6 \mathrm{ft}$ at the center. The tank was placed in service in 1943 to store waste from a radiochemical processing facility (Building 3019). The tank was removed from service in the 1960s because of suspected leakage. The tank is set on a concrete saucer with an associated dry well. The tank is surrounded by crushed rock and buried under $6 \mathrm{ft}$ of soil. An active ventilation system consisting of a fan and a HEPA filter will be used to ventilate the tank during sludge removal operations.

During sampling of the tank in August and September of 1994, the tank contained approximately 33,046 gal of liquid. A detailed sonar mapping of the sludge volume provided an accurate estimate of the sludge volume at $628 \mathrm{gal}$. In June 1995 , some of the supernate was removed and pumped to the active LLLW System leaving the tank with 15,688 gal of liquid in it. It is assumed that this volume remains in Tank W-3 at the sample concentrations. Process water will be added to the tank during sluicing and additional inleakage into the tank is possible. Because no new radiation sources will be added, inleakage of rain or groundwater and the process water will only dilute the liquid in the tank.

\subsubsection{Tank W-4}

Tank W-4 is a 42,500-gal underground, domed, gunite (reinforced concrete) tank located in the NTF. The tank has an inside diameter of $25 \mathrm{ft}$, a vertical sidewall height of $12 \mathrm{ft}$, and an additional dome height of $3.6 \mathrm{ft}$ at the center. The tank was placed in service in 1943 to store waste from a radiochemical processing facility (Building 3019). The tank was removed from service in the 1960 s because of suspected leakage. The tank is set on a concrete saucer with an associated dry well. The tank is surrounded by crushed rock and buried under $6 \mathrm{ft}$ of soil. An active ventilation system consisting of a fan and a HEPA filter will be used to ventilate the tank during sludge removal operations.

During sampling of the tank in August and September 1994, the tank contained approximately 21,590 gal of liquid. The current liquid level is $29,754 \mathrm{gal}$. It is assumed that the current volume is present at the sample concentrations. Process water will be added to the tank during sluicing and additional inleakage into the tank is possible. Because no new radiation sources will be added, inleakage of rain or groundwater and the process water will only dilute the liquid in the tank. A detailed sonar mapping of the sludge volume provided an accurate estimate of the sludge volume at $1313 \mathrm{gal}$.

\subsubsection{Tank W-13}

Tank W-13 was constructed $\sim 1950$ and continued in service until 1958. Tank W-13 received waste from the metal waste drain in a radiochemical processing facility (Building 3019) and also collected chemical waste from the recovery of fission products. It also collected waste from the Chemistry Division hot laboratories. Tank W-13 was emptied in 1992 leaving approximately $3 / 4$ inches remaining in the bottom. It was rechecked in November of 1993 and was still empty. For the analysis, the tank was assumed to contain a 25 gallon heel.

Tank W-13 is a type 347 stainless steel tank. Tank W-13 is a horizontal, cylindrical tank with a nominal capacity of $2000 \mathrm{gal}$. The tank is $6 \mathrm{ft}$ in diameter and is $11 \mathrm{ft}$ long. The tank rests on a concrete pad (along with Tank W-14) and is encased in a concrete vault (along with Tanks W-14 and W-15). The vault top is at grade. The height of the vault (from the bottom) is $7 \mathrm{ft} 6 \mathrm{in}$. The concrete vault has an associated dry well. No ventilation system is provided for Tank W-13. 


\subsubsection{Tank W-14}

Tank W-14 was constructed $\sim 1950$ and continued in service until 1958. Tank W-14 received waste from the metal waste drain in a radiochemical processing facility (Building 3019 ) and also collected chemical waste from the recovery of fission products. Tank W-14 also collected waste from the radioisotope facilities. Tank W-14 was emptied in 1992 leaving approximately $1 / 2$ inches remaining in the bottom. It was rechecked in November of 1993 and was still empty. For the analysis, the tank was assumed to contain a 25 gallon heel.

Tank W-14 is a type 347 stainless steel tank. Tank W-14 is a horizontal, cylindrical tank with a nominal capacity of $2000 \mathrm{gal}$. The tank is $6 \mathrm{ft}$ in diameter and is $11 \mathrm{ft}$ long. The tank rests on a concrete pad (along with Tank W-13) and is encased in a concrete vault (along with Tanks W-13 and W-15). The vault top is at grade. The height of the vault (from the bottom) is $7 \mathrm{ft} 6 \mathrm{in}$. The concrete vault has an associated dry well. No ventilation system is provided for Tank W-14.

\subsubsection{Tank W-15}

Tank W-15 was constructed $\sim 1950$ and continued in service until 1958. Tank W-15 received waste from the metal waste drain in a radiochemical processing facility (Building 3019) and also collected chemical waste from the recovery of fission products. Tank W-15 also collected waste from the radioisotope facilities. Tank W-15 was emptied in 1992 leaving approximately $1 / 8$ inches remaining in the bottom. The tank was rechecked in November 1993 and was still empty. For the analysis, the tank was assumed to contain a 25 gallon heel.

Tank W-15 is a type 309 stainless steel tank. Tank W-15 is a vertical, cylindrical tank with a nominal capacity of 2000 gal. The tank is $8 \mathrm{ft}$ in diameter and is $6 \mathrm{ft}$ tall. The tank rests on a concrete pad and is encased in a concrete vault (along with Tanks W-13 and W-14). The vault top is at grade. The height of the vault (from the bottom) is $7 \mathrm{ft} 6 \mathrm{in}$. The concrete vault has an associated dry well. No ventilation system is provided for Tank W-15.

\subsubsection{North Tank Farm Activities and Processes}

The NTF tanks are all inactive (i.e., they no longer receive waste from active facilities). Surveillance and maintenance activities are the only normal operations occurring at the NTF. The following sections discuss the surveillance and maintenance activities at the NTF.

\subsubsection{Site inspections}

Weekly site inspections are required for the NTF tanks. Inspections include visual inspection of the site for placement and condition of physical barriers (fences, chains, gates, etc.), grass and vegetation maintenance, placement of manhole covers, and general housekeeping. Site inspections for the tank systems are recorded on formal surveillance and maintenance checklists.

\subsubsection{Waste tank monitoring}

Tank inventory levels are monitored continuously for Tank W-1A at the Waste Operations Control Center (WOCC), checked daily for Tanks W-1 and W-2, checked weekly for Tanks W-3 and W-4, and checked annually for Tanks W-13, W-14, and W-15. The inventory status for Tanks W-13,W-14, and W-15 is provided to the Inactive Liquid Low-Level Waste Tank Manager. The inventory status for Tanks W-1, W-1A, W-2, W-3, and W-4 are entered into a tank level tracking system. 


\subsubsection{Dry well monitoring}

Monitoring of the dry wells associated with the NTF tanks is required to be performed monthly. If liquid is detected in the dry well, a sample is drawn and sent for analytical testing. This sample is used to give an indication of radionuclide concentration in the groundwater in the vicinity of the $\operatorname{tank}(\mathbf{s})$. Information from dry well monitoring is entered into the tank database and is reviewed by the facility manager periodically.

\subsubsection{Off-gas system monitoring}

Tank W-1A is the only tank in the NTF that has any identified off-gas equipment. Tank W-1A is equipped with a HEPA filter to minimize airborne releases from the tank. DOP testing of the HEPA filter is required quarterly. Problems associated with off-gas equipment are the responsibility of the facility manager and are addressed on a timely basis.

\subsubsection{Radiological survey and inventory characterization}

Radiological surveys for the NTF tanks are required on a semi-annual basis. The surveys are requested by the facility manager and conducted by the Office of Radiation Protection procedures. Each area which requires radiological surveys is labeled as a "Regulated Area." Survey maps that are developed through the survey are maintained by the facility manager.

Tank inventory radiological and chemical characterization documentation is to be maintained by the facility manager. If the tank's inventory is substantially disturbed, new analysis to reflect the current liquid and sludge (if present) is necessary.

\subsubsection{North Tank Farm Utility Support Systems}

The utility support systems for the NTF include electrical power for lighting and instrumentation, steam for steam jets, and compressed air for instrumentation. Both are supplied by site distribution systems.

\subsection{TANK W-11}

\subsubsection{Tank W-11 Structures and Systems}

Tank W-11 is a 1500-gal underground, gunite (reinforced concrete) tank located southeast of the STF. The tank has an inside diameter of $8 \mathrm{ft}$ and is $5-1 / 2 \mathrm{ft}$ high at the center of the tank. The tank is buried underground approximately $6 \mathrm{ft}$ and is vented to the atmosphere through a HEPA filter. A staff gauge is available for level monitoring. The tank was placed into service in 1943 to collect, monitor, and store waste generated by various laboratories in Building 3550 . The tank was reportedly emptied when it was removed from service in 1948.

The tank contained approximately 772 gal of supernate at the last sampling. It is also believed to contain a small quantity of sludge. The tank is known to receive some inleakage. 


\subsubsection{Tank W-11 Activities and Processes}

Tank W-11 is inactive (i.e., it no longer receives waste from active facilities). Surveillance and maintenance activities are the only normal operations occurring. The following sections discuss the surveillance and maintenance activities for Tank W-11.

\subsubsection{Site inspections}

Tank W-11 site inspections are required weekly. Inspections include visual inspection of the site for placement and condition of physical barriers (fences, chains, gates, etc.), grass and vegetation maintenance, and general housekeeping. Site inspections for Tank W-11 are recorded on formal surveillance and maintenance checklists.

\subsubsection{Waste tank monitoring}

Tank inventory level is monitored weekly. The weekly inventory status is entered into a tank level tracking system.

\subsection{GUNITE AND ASSOCIATED TANKS - TREATABILITY STUDY}

The Treatability Study involves the demonstration of sludge removal technology. For the purposes of this report, the Treatability Study includes Tanks W-3 and W-4, the interconnecting piping, and the equipment used to dislodge and transfer sludges from the tanks during the time when the Treatability Study equipment is installed in Tanks W-3 and W-4. The Treatability Study will use a high pressure confined sluicing end effector (CSEE) attached to the end of a MLDUA or to a Remote Operated Vehicle for the sludge removal operations described in this report. The overall system configuration for sludge removal operations is shown in Fig. 2.1. The in-tank configuration for sludge removal operations using the MLDUA is shown in Fig. 2.2 and the in-tank configuration for sludge removal operations using the Remote Operated Vehicle is shown in Fig. 2.3. Both the MLDUA and the Remote Operated Vehicle may be used in the same tank at the same time. However, there is only one CSEE.

\subsubsection{Treatability Structures and Systems}

\subsubsection{Decontamination tent}

A temporary decontamination tent is located near the east end of Building 3505 . The tent is used as a work area for decontamination of equipment removed from Tanks W-3 and W-4.

\subsubsection{Remote operated vehicle}

The remote operated vehicle is shown in Fig. 2.4. The remote operated vehicle's purpose is to provide a means of deploying the CSEE within Tanks W-3 and W-4. The vehicle is remotely operated by a controller that will be located in the control trailer by having the operator view the vehicle in its working environment through overhead camera systems as well as local camera systems located on the vehicle. The vehicle is equipped with two tools: (1) the manipulator gripper, and (2) the plow. The gripper is used to grab and deploy sensors and systems in the tanks as well as retrieval of wastes in the tanks. The plow is used to push the solid or slurry waste to the remediation systems such as the CSEE. 


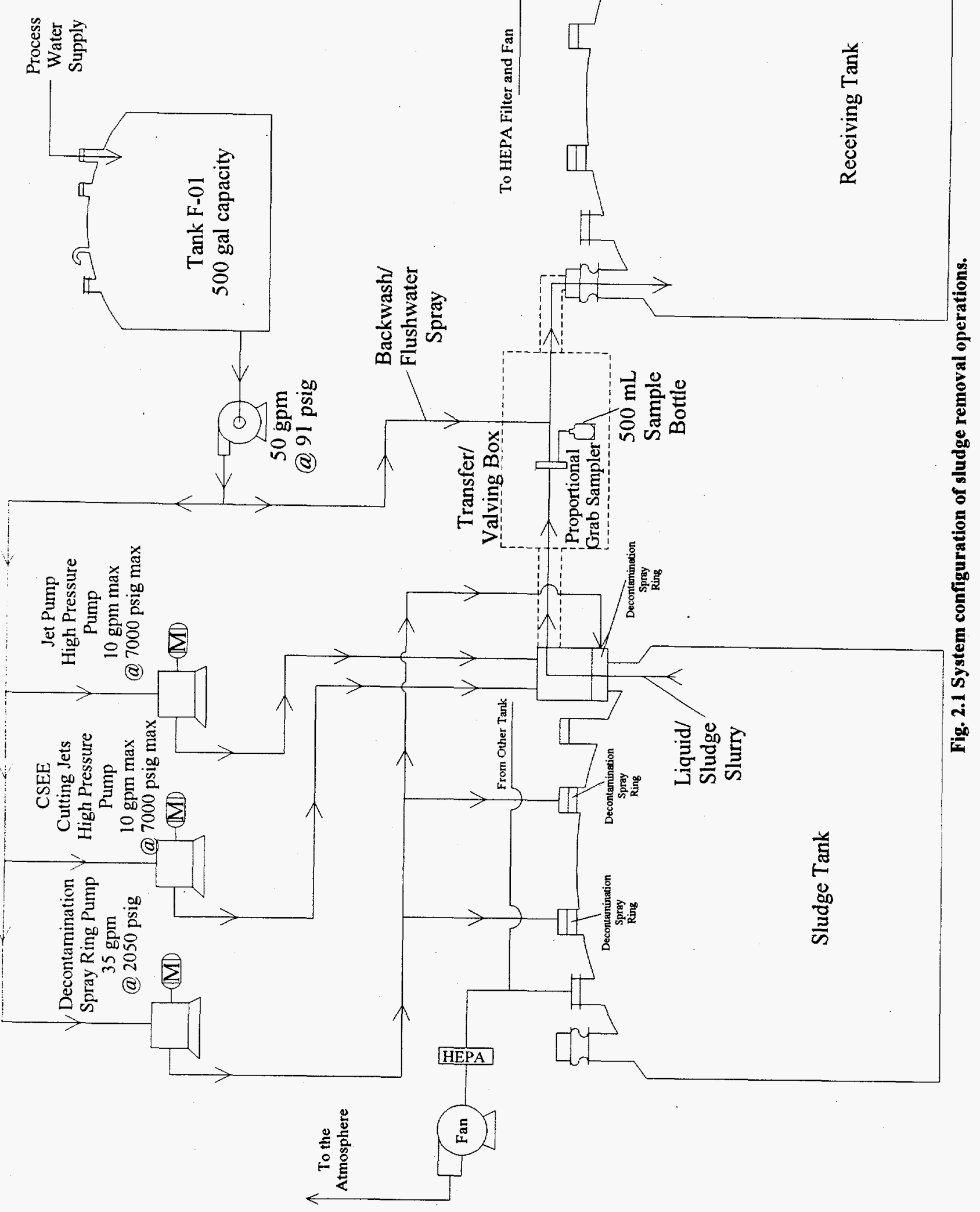




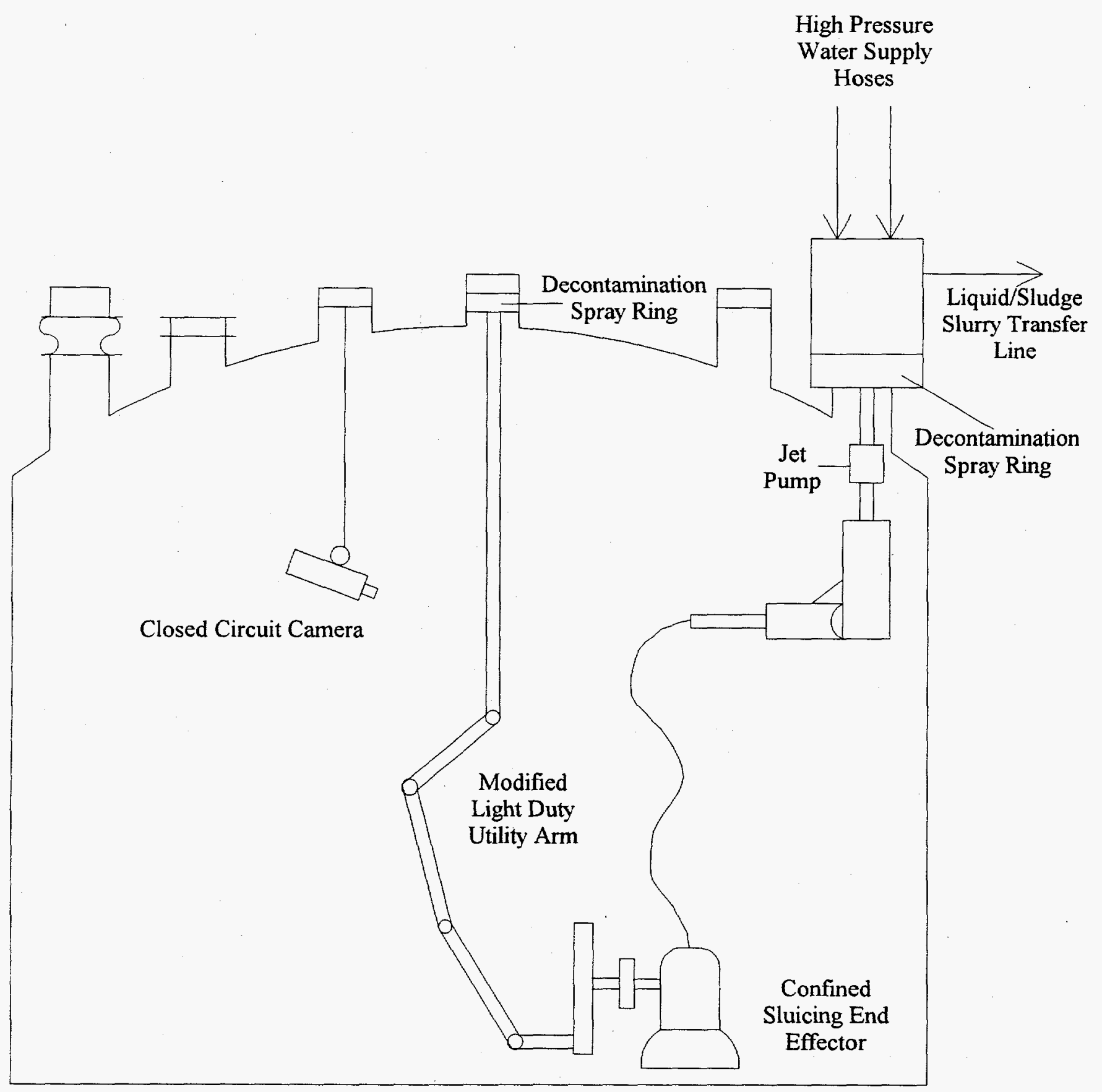

Fig. 2.2 In-tank equipment configuration for sludge removal using the MLDUA. 


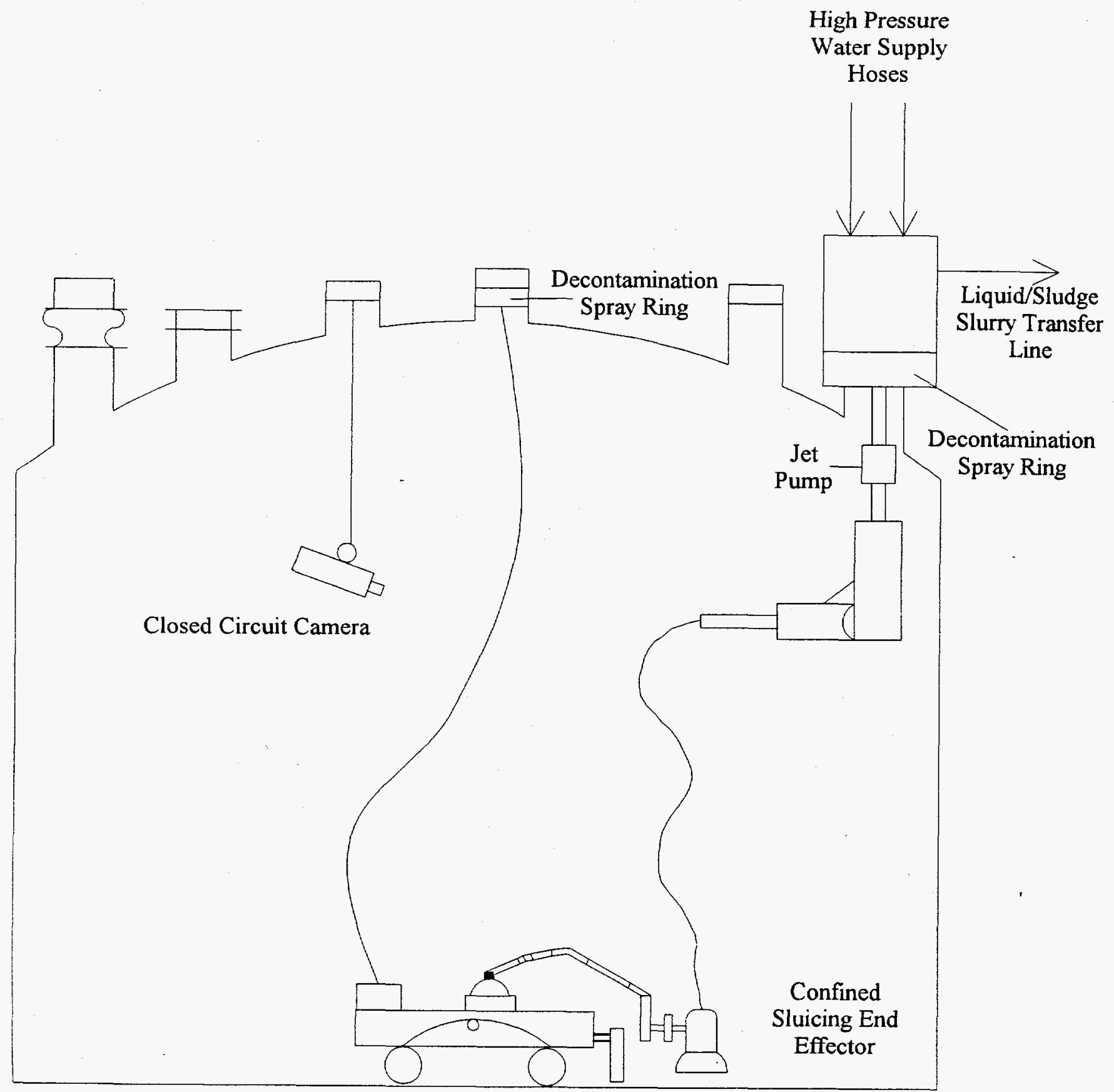

Fig. 2.3 In-tank equipment configuration for sludge removal using the remote operated vehicle. 


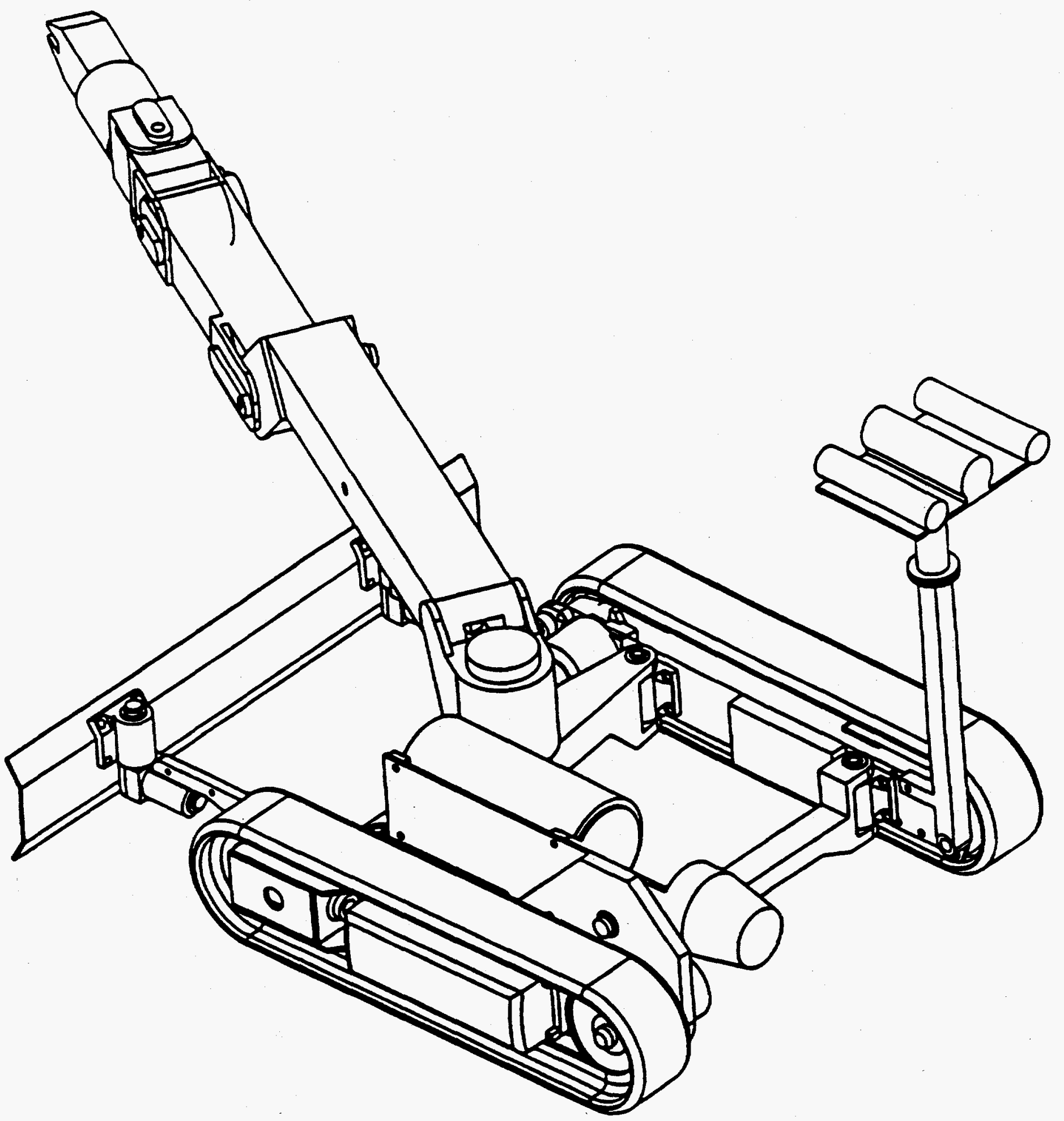

Fig. 2.4 Remote operated vehicle. 
The vehicle is a tethered, hydraulically-powered, track-driven, teleoperated, work machine with an expandable frame chassis that allows it to fit through a $0.61 \mathrm{~m}$ nominal diameter opening. When fully deployed, the vehicle has a footprint that is $1.1 \mathrm{~m}$ wide and $1.2 \mathrm{~m}$ in length. The vehicle is capable of moving over and through a variety of waste forms. It can operate fully submerged as long as sufficient support and traction is available.

The manipulator gripper has 6 degrees of freedom and is mounted to the vehicle frame and is used for object retrieval and operation of specialized tooling. The manipulator is made of corrosion resistant titanium and can also be fully submerged. The standard interface to the manipulator is through the slave controller (mounted on the vehicle) and a "master" consolette that is integrated into control console.

The vehicle is also equipped with a plow blade for breaking up heels at the bottom of the tanks and mobilizing (pushing) this material to a waste conveyance system (pump) for removal. The plow is instrumental in moving solid wastes from the edges to the center of the tank. Removable squeegees on the bottom and sides of the plow ensure that as much waste as possible is removed from the tank.

Two cameras are available on the vehicle. The first camera has two lights for illumination and is mounted to a pan and tilt unit. The standard mounting of this unit is to the rear of the right track, several inches above track height. This camera is used for driving the vehicle, monitoring the tether, and gross positioning of the manipulator arm when attempting to grasp an object. The second camera is fixed to the manipulator arm, near the gripper. There are two lights mounted adjacent to the camera to illuminate the area directly in front of the grippers. This camera provides two functions. First, it provides a useful view for performing dexterous tasks and second it can also be used for driving.

The operating console provides the operator with joysticks, foot pedals, a six degree of freedom master consolette, switches, and remote-viewing monitors to allow the operator to control the system from a remote location.

\subsubsection{Modified light duty utility arm system}

The MLDUA provides a means of deploying various characterization and retrieval tools from above ground, through access penetrations, to the inside of Tanks W-3 and W-4. Other tools, such as the CSEE may be deployed separately and then grasped and manipulated by the MLDUA. The MLDUA provides a remotely operated system for positioning these tools within the tank volume, in the waste, and in contact with the tank structure.

The MLDUA is a seven degree of freedom arm that enters the tank through a riser port. Five of the degrees of freedom use hydraulic actuators and two degrees of freedom use stepper motor actuators. The MLDUA is attached to a two piece extendable mast that is used to vertically lower and raise the arm into and out of the tank. The mast is contained in a positive pressure housing. The housing is placed in the horizontal orientation for travel and storage and is raised to the vertical orientation for arm deployment into a tank. The mast is supported and positioned over the tank riser by the Mobile Deployment System (MDS).

A gripper end effector is located on the end of the MLDUA and allows the arm to grasp objects. There are two cameras with lights located above the shoulder joint on the mast arm. The cameras and lights have a mechanism for pan and tilt. The cameras are equipped with auto focus and zoom. The MLDUA is controlled by the operator using two joysticks from a remote operating console. 


\subsubsection{Cutting/dislodging system}

The purpose of the Cutting/Dislodging System (CDS) is to dislodge and/or cut tank waste material and to force the material toward the inner shroud opening of the CSEE. The CDS is also capable of scarifying the tank gunite material from the tank structure for retrieval of contaminated material.

The CSEE uses three high pressure water jets directed at the waste surface to break up and dislodge the waste. The three water jets require approximately $10 \mathrm{gpm}$ of water at 3,000 to $7,000 \mathrm{psi}$. An electric motor rotates the jet carrier between 0 to $600 \mathrm{rpm}$. The axis of rotation is normal to the waste surface. A sealed enclosure houses the motor drive and the jet carrier. This enclosure is mounted concentric to and outside the conveyance system inner shroud, which captures the dislodged waste and water and directs the collected waste to a jet pump conveyance system.

\subsubsection{Hose management system}

The Hose Management System (HMS), with the aid of the MLDUA or the Remote Operated Vehicle, deploys the CSEE into different sections of the tank. The HMS consists of the Waste Dislodging and Conveyance (WD\&C) Confinement Box, the storage tube, mast, and Hose Management Arm. The HMS supports the piping and conduit for the Cutting/Dislodging System and the Sluicing System to allow conveyance of the waste from one tank to another. The HMS is supported from a structural platform which bridges both Tanks W-3 and W-4.

The Hose Management Arm is a 2-in. pipe double-jointed bulk material loading arm that is fitted with position sensors, a hose bundle, support cable, yaw joint drive motor, and various small diameter hoses and cables.

The mast assembly is a long, semi-circular pipe section that contains a jet pump, various small diameter hoses, pipes, tubing, rupture disk, and support cable. The mast has a swing arm guide to assist in placement of the Hose Management Arm and to secure it during arm retraction and stowage.

The storage tube is a long cylindrical container that stores the Hose Management Arm and the mast as an assembly during periods of transportation, maintenance, and off-platform storage. The tube contains guide rails that index the rotational position of the Hose Management Arm and mast in the confinement box.

The confinement box serves three basic functions: to provide (1) secondary containment for the waste piping located inside the confinement box, (2) operator access for operational and maintenance activities, and (3) structural/mechanical support for the mast, Hose Management Arm, and storage tube.

\subsubsection{Sluicing system description}

The purpose of the sluicing system is to siphon and collect the sludges from inside the tanks and transfer the sludge to the desired location. During the Treatability Study, this desired location will be to transfer the sludge between Tank W-3 and Tank W-4.

Suction is provided by a jet pump mounted in the HMS arm. The jet pump motive force is high pressure water. This water becomes part of the sludge stream once introduced in the jet pump. At the discharge of the jet pump, and after the sludge hose exits the tank, the sludge enters the transfer/valving box which provides double containment for a series of back flush and flow control valves, a flow meter, and a proportional sampler. 


\subsubsection{Decontamination spray module}

The decontamination spray module is a device that is placed into and onto the tank riser for the purpose of water cleaning equipment that is removed through the riser. The system is designed to operate at 2,000 psig at the spray nozzles and has an impact pressure of about $1.5 \mathrm{psi}$ on the surface being cleaned and decontaminated.

\subsubsection{Treatability Processes}

The Treatability Study operations include installation of supporting equipment, setup and removal of mobile equipment, decontamination of removed equipment, and sludge removal operations. The sludge removal is accomplished by remotely manipulating the CSEE using either the MLDUA or the Remote Operated Vehicle. The sludge is dislodged from the tank using high pressure water and removed using a jet pump. The sludge mixture is then transferred through transfer piping to the other tank.

\subsubsection{Treatability Utility Support Systems}

\subsubsection{Compressed air system}

The compressed air system consists of a skid-mounted compressor and receiver, and a distribution header and hose connections to the various process equipment and instruments requiring compressed air. The system is designed to provide $34 \mathrm{cfm}$ of dry, oil-free compressed air at a pressure of $175 \mathrm{psig}$ at the skid discharge. The compressor is driven by an electric motor and provided with an inlet air filter to remove moisture, an $80 \mathrm{gal}$ receiver, high efficiency filters to remove particulates to 0.1 microns, and a desiccant dryer.

\subsubsection{Electrical system}

The electrical system provides a connection to the ORNL power system and distribution to the operations control trailer and various systems and process equipment located on and around the equipment platform. The system provides $480 / 240 / 120 \mathrm{~V} \mathrm{AC}$ power supplied from the ORNL power grid via a new $300 \mathrm{kVA}$ transformer bank. Power will be distributed in a conduit bank to the platform, where the conduit is mounted in cable trays, and branched to junction boxes where the power supply to the equipment located on the platform will be connected. Additional conduit branches will be routed to provide stub up points for the individual equipment skids to connect.

\subsubsection{Process water system}

The process water system consists of a connection to the ORNL process water system, the Process Water Supply Tank (F-01), process water pump, and connections for supplying water to the various systems. The connection to the ORNL water system is provided with a backflow preventer and a manual valve to open/close the connection. The tank, pump, and discharge header are located on a common skid.

The Process Water Supply Tank has a capacity of 500 gal to provide a surge capacity for bypass from the high pressure systems and flush supply in the event of loss of ORNL water supply. The tank is equipped with level switches to open/close a water supply valve on low/high level in the tank to maintain the necessary water volume in the tank. The process water supply line is also equipped with a backflow preventer. 
The Process Water Pump is a locally operated, electric motor driven centrifugal pump capable of supplying $50 \mathrm{gpm}$ at a discharge pressure of $91 \mathrm{psig}$. At the discharge of the pump, the discharge header supplies flow to:

- the Sluicing System transfer valving box for line flushing operations,

- the jet pump high pressure water pump,

- the CSEE cutting jets high pressure water pump,

- the Decontamination Spray Ring Supply Pump,

- and a supply/return line to the Process Water Supply Tank.

\subsubsection{Ventilation system}

Tanks W-3 and W-4 are ventilated by a portable exhaust fan and HEPA filter. The tanks are connected to the portable unit with flexible ducting. The portable unit has a HEPA filter differential pressure indication. The pressure in each tank is indicated and alarmed. Discharge will be sampled by ORNL Environmental Compliance. 



\section{HAZARD ANALYSIS}

- The purpose of this chapter is to systematically identify and evaluate the hazards associated with the NTF, Tank W-11 and the operations of the GAAT-TS at the ORNL. This purpose is accomplished in two basic steps: (1) hazard identification and facility hazard classification, and (2) hazard analysis. In the first step, internal facility hazards are identified and the facility hazard classification is made by comparing the hazardous material inventories with specified threshold quantities. The hazard analysis considers the complete spectrum of accidents that may occur due to facility operations; analyzes potential accident consequences to the public and workers; estimates likelihood of occurrence; and identifies and assesses associated preventive and mitigative features.

This chapter contains the following information:

- Description of the methodology for and approach to hazard analysis

- Identification of hazardous materials and energy sources by type, quantity, form, and location

- Initial facility hazard classification, including segmentation in accordance with DOE-STD-1027-92

- Identification, in the hazard analysis, of the spectrum of potential accidents at the facility in terms of qualitative consequence and frequency estimates.

- Final facility hazard classification considering physical properties of hazardous materials and the forms and magnitudes of the energy sources present during the accident scenarios identified in the hazard analysis.

\subsection{REQUIREMENTS}

The requirements for hazards analysis are contained in DOE Order $5480.23 .^{2}$ Recommended practices for hazard screening and analysis are included in DOE-STD-3009-94, ${ }^{3}$ DOE-STD-1027-92, ${ }^{1}$ and ES/CSET-2/R2. ${ }^{4}$

\subsection{HAZARD IDENTIFICATION AND ANALYSIS METHODOLOGY}

This section includes the methodology used to identify and characterize hazards and to perform a systematic evaluation of basic accidents.

\subsubsection{Hazard Identification and Preliminary Facility Hazard Classification Methodology}

The hazard types associated with the NTF, Tank W-11, and GAAT-TS operations are those provided in ES/CSET-2/R2. ${ }^{4}$ The methodology consisted of dividing the facility into systems and identifying hazards in the individual systems using a checklist of 18 different hazard types. The 18 different hazard types on the checklist were: 


\section{Hazardous Materials}

1. Radioactive materials (including fissionable materials)

2. Radioactive surface contamination

3. Radioactive waste

4. Toxic materials (including combustion products)

5. Carcinogens

6. Biohazards

7. Asphyxiants

8. Flammable materials

9. Reactive materials

10. Explosive materials

11. Incompatible chemical reaction products

\section{Energy Sources}

12. Electrical energy sources

13. Kinetic energy sources

14. High pressure energy sources

15. Potential energy sources

\section{Special Equipment}

16. Lasers

17. Accelerators

18. X-ray machines

Hazard identification was accomplished by reviewing facility documentation and drawings, conducting discussions with design and operations staff, and performing facility walkdowns where possible. Each buried tank in the NTF and Tank W-11 is considered an independent facility segment for surveillance and maintenance activities. These unpressurized tanks contain residual supernate and sludges with no processing. Inleakage is occasionally transferred to the active LLLW System. Tanks W-3 and W-4 along with the sludge removal system and associated support equipment will be considered as one segment for facility classification purposes for Treatability Study operations. Tanks W-13, -14, and -15 are in a common vault and are considered a separate segment.

The hazards identified were analyzed and screened, in accordance with the criteria in ES/CSET-2/R2, 40 CFR 302.4, ${ }^{5}$ and DOE-STD-1027-92, ${ }^{1}$ to eliminate from further consideration the insignificant, routine, and standard industrial hazards.

Insignificant and routine hazards were considered to be those of the type and magnitude routinely encountered by the public and workers in everyday life and the workplace (equal to or lower in magnitude than the preliminary hazard screening criteria in ES/CSET-2/R2 ${ }^{4}$ ). Standard industrial hazards were considered to be those hazards that are not insignificant or routine, but are encountered in general industry in appropriate applications that are adequately controlled by the Occupational Safety and Health Administration (OSHA) regulations or one or more national consensus standards [e.g., American Society of Mechanical Engineers (ASME), American National Standards Institute (ANSI), National Fire Protection Association (NFPA), National Institute of Standards and Technology (NIST)]. These standards are adequate to define special safety requirements, unless they are in quantities or situations that can significantly impact large numbers of people. 
The occupational hazards that could not be screened out as insignificant and routine hazards were then further evaluated to determine if they could be considered standard industrial hazards. For the occupational hazards screened out as standard industrial hazards, the regulations and standards used to control the hazards are stated.

The remaining hazards that could not be screened out by this process are evaluated further in the hazard analysis.

Preliminary nuclear and a non-nuclear hazard classifications are specified for each facility segment. The preliminary nuclear categorization logic is shown in Fig. 3.1. Radiological hazards are compared with the 40 CFR $302^{5}$ Reportable Quantity (RQ) values, and the Category 3 and Category 2 threshold quantities (TQ) in DOE-STD-1027-92. ${ }^{1}$ Facilities with radioactive material inventories above the Category 2 TQs are considered Nuclear Category 2 Facilities. Facilities with radioactive material inventories below the Category $2 \mathrm{TQs}$, but above the Category $3 \mathrm{TQs}$, are considered Nuclear Category 3 Facilities. Facilities with radioactive material inventories below the Category $3 \mathrm{TQs}$, but above the RQ values in 40 CFR 302,5 are considered Radiological Facilities. All other facilities are considered Industrial Facilities.

The preliminary non-nuclear hazard classification for chemical hazards was completed by comparing the identified inventories with RQ values in 40 CFR 302. ${ }^{5}$ Chemical inventories below the RQ values in 40 CFR $302.4^{5}$ are considered insignificant and the non-nuclear facility classification is "Industrial." Significant chemical hazards (>40 CFR $302.4^{5}$ RQs) are evaluated for the consequential health effects using the methodology from ES/CSET-2/R2. ${ }^{4}$ The health effects from nonradiological hazards for High, Moderate, Low, and Industrial facilities are listed in Table 3.1 in terms of reversible, irreversible, and negligible effects. The definitions of these terms from ES/CSET-2/R2 ${ }^{4}$ are included in Table 3.2 .

The NTF tanks and Tank W-11 are inactive. As such, they are no longer receiving radioactive waste from generating facilities. With the exception of the GAAT-TS, radioactive material in the tanks will not be transferred between tanks. Occasionally, liquids may be removed from the tanks to the LLLW System.

\subsubsection{Hazard Analysis Methodology}

Processes at the NTF, Tank W-11, and in the GAAT-TS are relatively simple. Radioactively contaminated liquid waste is monitored, sampled, pumped, and stored. Therefore, a relatively simple method of hazard evaluation is appropriate. The hazards identified in the facility systems are evaluated using a PHA to identify accident scenarios and evaluate the effectiveness of the preventive and mitigative features provided. The PHA includes a fact sheet (identifying hazards of interest, systems, energy sources, and operations/process/activities) and an accident identification table. The accident identification table identifies natural phenomena as well as internal and external events that may result in an accident at the facility system. The table qualitatively shows the consequences. The purpose of the PHA for radiological facilities is to demonstrate an understanding of the facility, the hazards, and the potential accidents, and to identify preventers, detectors, and mitigators that provide defense-in-depth for on-site workers and off-site personnel. 


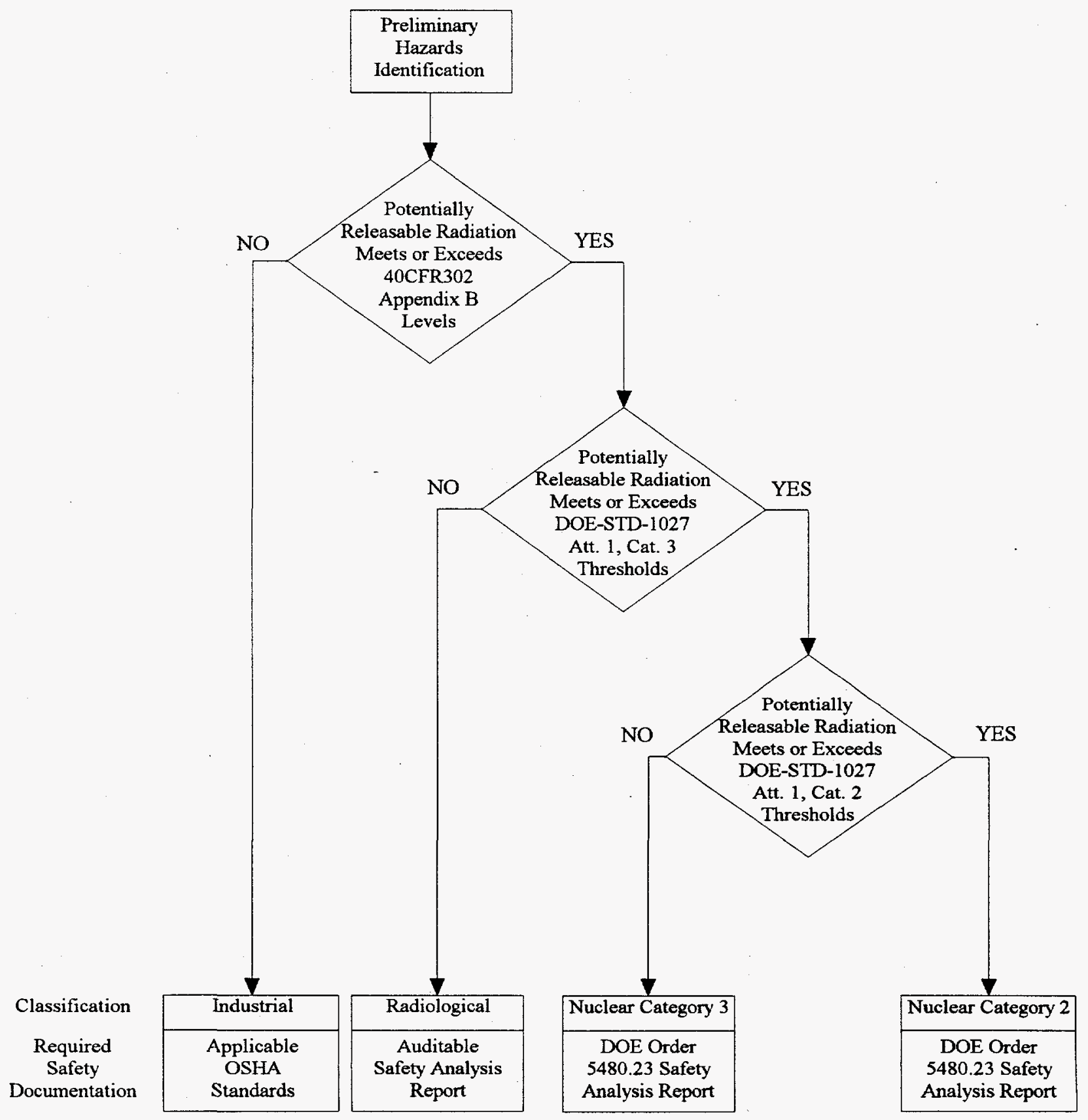

Fig. 3.1. Preliminary nuclear facility hazard categorization logic process. 
Table 3.1. Non-radiological hazard screening health effects criteria

\begin{tabular}{|c|c|c|}
\hline Hazard class & On-site & Off-site \\
\hline $\mathrm{HIGH}$ & \multicolumn{2}{|c|}{ Designated by DOE } \\
\hline MODERATE & $\begin{array}{l}\text { Irreversible effects to any individual } \\
\text { not present in the immediate } \\
\text { operating area of the accident }\end{array}$ & $\begin{array}{l}\text { Irreversible effect to any person } \\
\qquad \mathrm{OR} \\
\text { Reversible effect to a large number } \\
\text { of people }\end{array}$ \\
\hline LOW & $\begin{array}{l}\text { Irreversible effects to a few } \\
\text { individuals present in the immediate } \\
\text { operating area of the accident } \\
\text { Reversible effect to a large or very } \\
\text { large number of number of people }\end{array}$ & Reversible effects to a few people \\
\hline OTHER INDUSTRIAI & $\begin{array}{l}\text { Consequences less than that defined } \\
\text { for "low" }\end{array}$ & $\begin{array}{l}\text { Consequences less than that defined } \\
\text { for "low" }\end{array}$ \\
\hline
\end{tabular}

Table 3.2. Chemical health effect exposure levels

If actual information is available on the boundary between irreversible and reversible health effects, and the boundary between reversible and negligible health effects, this information should be used instead of the IDLH values. Otherwise use the information below.

\begin{tabular}{|c|c|}
\hline IRREVERSIBLE: & CONCENTRATION $>1.0 *$ IDLH \\
\hline REVERSIBLE: & $0.1 *$ IDLH $\leq$ CONCENTRATION $\leq 1.0 *$ IDLH \\
\hline NEGLIGIBLE: & CONCENTRATION $<0.1 *$ DLH \\
\hline
\end{tabular}

Note: These exposure levels are only to be used for facility classification.

Chemical concentrations should be the highest five minute time-weighted-average. If IDLH values are not available, use the following as equivalent. They are listed in decreasing order of preference.

$$
\begin{aligned}
& 0.1 * \mathrm{LC}_{50} \\
& 1.0 * \mathrm{LC}_{\mathrm{LO}} \\
& 0.01 * \mathrm{LD}_{50} \\
& 0.1 * \mathrm{LD}_{\mathrm{LO}} \\
& 500 * \mathrm{TLV}
\end{aligned}
$$




\subsubsection{Final Facility Hazard Classification}

When all hazardous materials and energy sources have been identified and a hazard analysis has identified credible accident scenarios wherein the energy sources and material may interact, a final facility hazard categorization may be determined in accordance with requirements in DOE Order $5480.23 .^{2}$

DOE Order $5480.23^{2}$ states that "contractors shall be required to perform a hazard analysis of their nuclear activities and classify their processes, operations, or activities... The consequences of unmitigated releases of radioactive and/or hazardous material shall be evaluated and classified by the following hazard categories:"

- Category 1: The hazard analysis shows the potential for significant off-site consequences.

- Category 2: The hazard analysis shows the potential for significant on-site consequences.

- Category 3: The hazard analysis shows the potential for only significant localized consequences.

Facilities which are shown to pose no "significant localized consequences" are assumed to be "Radiological" facilities.

For the purpose of this analysis the DOE-STD-1027-92 ${ }^{1}$ definition for significant localized consequences is used. The distance from the point of release to the point of exposure is $30 \mathrm{~m}$. The doseequivalent limit is 10 rem effective whole body, dose and there is no radioactive decay (for the sake of conservatism and simplicity). Inhalation, ingestion, and direct exposure pathways are considered.

Inhalation and direct exposure doses are considered for persons located $30 \mathrm{~m}$ from the source. Inhalation doses are calculated using the Environmental Protection Agency's (EPA) Industrial Source Code (ISC) Short Term (ST) dispersion model. Releases are assumed to be non-buoyant, ground-level releases, and the receptor is assumed to be located at the plume centerline for the duration of the release.

Ingestion is not credible for local receptors.

Direct exposure doses are calculated using the Microshield Program from Grove Engineering, Inc. The released material is assumed to be a point source located $30 \mathrm{~m}$ from the receptor with no shielding between the source and the receptor. The exposure time is assumed to be $24 \mathrm{hrs}$.

\subsection{HAZARD IDENTIFICATION RESULTS}

\subsubsection{North Tank Farm}

\subsubsection{Hazard identification}

The hazard identification tables for the NTF facility tanks are included in Appendix A. Table 3.3 summarizes the hazards identified in each of the NTF tanks. 
Table 3.3. Preliminary hazards identification results for the North Tank Farm tanks

\begin{tabular}{||c|c|c|c|c|c|c|c|c|c||}
\hline \hline Tank & $\begin{array}{c}\text { Fissionable } \\
\text { materials }\end{array}$ & $\begin{array}{c}\text { Rad } \\
\text { sources }\end{array}$ & $\begin{array}{c}\text { Toxic/ } \\
\text { corrosive/ } \\
\text { reactive } \\
\text { materials }\end{array}$ & $\begin{array}{c}\text { Flammable } \\
\text { materials }\end{array}$ & $\begin{array}{c}\text { Explosivel } \\
\text { pyrophoric } \\
\text { materials }\end{array}$ & $\begin{array}{c}\text { Electrical } \\
\text { energy } \\
\text { sources }\end{array}$ & $\begin{array}{c}\text { Thermal } \\
\text { energy } \\
\text { sources }\end{array}$ & $\begin{array}{c}\text { Kinetic } \\
\text { enerzy } \\
\text { sources }\end{array}$ & $\begin{array}{c}\text { Potential } \\
\text { energy } \\
\text { suurces }\end{array}$ \\
\hline W-1 & $\bullet$ & $\bullet$ & $\bullet$ & $\bullet$ & & $\bullet$ & & & \\
\hline W-1A & $\bullet$ & $\bullet$ & $\bullet$ & $\bullet$ & & $\bullet$ & & & $\bullet$ \\
\hline W-2 & $\bullet$ & $\bullet$ & $\bullet$ & $\bullet$ & & $\bullet$ & & & \\
\hline W-3 & $\bullet$ & $\bullet$ & $\bullet$ & $\bullet$ & & & & & \\
\hline W-4 & $\bullet$ & $\bullet$ & $\bullet$ & $\bullet$ & & & & & \\
\hline W-13 & $\bullet$ & $\bullet$ & $\bullet$ & $\bullet$ & & $\bullet$ & & & \\
\hline W-14 & & $\bullet$ & $\bullet$ & $\bullet$ & & $\bullet$ & & & \\
\hline W-15 & $\bullet$ & $\bullet$ & $\bullet$ & $\bullet$ & & $\bullet$ & & & \\
\hline
\end{tabular}

Hazards identified in Appendix A for the NTF facility tanks include fissionable materials, radiation sources, toxic/corrosive/reactive materials, flammable materials, electrical energy sources, and potential energy sources. Fissionable materials are present in the tanks as various isotopes of uranium, plutonium, neptunium, americium, and curium. Table 3.4 lists the fissionable materials present and calculates the ${ }^{235} \mathrm{U}$ fissionable equivalent mass in each tank following the guidance provided in ORNL Nuclear Criticality Safety Procedure NCS-1.0. All the facility tanks except W-3 and W-4 contain amounts of fissionable materials well below the fissionable material control limit for ${ }^{235} \mathrm{U}$ of $250 \mathrm{~g}$ specified in ORNL NCS-1.0.

Mass spectrometry indicates that the uranium present in the liquids and sludges in Tanks W-3 and W-4 is at natural concentrations. In discussions with the ORNL Criticality Safety Section, a review of ANSI/ANS-8.12 and ANSI/ANS-8.1 indicates that the amount of ${ }^{233} \mathrm{U}$ or ${ }^{239} \mathrm{Pu}$ that must be added to natural uranium to achieve criticality exceeds the category 2 threshold amounts provided for those isotopes in DOE-STD-1027-92.' Therefore the effects of the ${ }^{235} \mathrm{U}$ are such that the ${ }^{235} \mathrm{U}$, when in a natural or depleted ratio with ${ }^{238} \mathrm{U}$, does not need to be added to the fissionable mass equivalent when considering the criticality limits for hazard classification for DOE-STD-1027-92.'

The total amount of fissionable material (excluding natural uranium) in each tank and in the entire NTF is less than the fissionable material control limit ( $250 \mathrm{~g}{ }^{235} \mathrm{U}$ fissionable equivalent mass). None of the tanks in the NTF are receiving new radioactive materials. Therefore, an inadvertent criticality accident is not credible for the NTF facility tanks. The fissionable material hazard is screened out and is not retained for further evaluation.

Radioactive materials are present in all of the tanks in the NTF. Tables 3.5 through 3.12 list the best estimate of each tank inventory and compare the inventory to the Reportable Quantity (RQ) values in Title 40, CFR Sect. 302.4 (40 CFR 302.4). ${ }^{5}$ Tanks W-1, W-1A, and W-2 contain quantities of radioactive materials that do not exceed the $R Q$ values. For these tanks, the radioactive material hazard is not considered to represent a significant risk to on-site or off-site personnel and is screened out from further consideration. Tanks W-3 and W-4 contain quantities of radioactive material that exceed RQ values. Tanks W-13, W-14, and W-15 have been emptied. For conservatism it is assumed that there are 25 gal of LLLW present at the last sampled concentrations. Using this assumption, Tanks W-13, W-14, and W-15 contain quantities of radioactive materials that exceed RQ values. For Tanks $W-3, W-4$, $\mathrm{W}-13, \mathrm{~W}-14$, and $\mathrm{W}-15$, the radioactive material hazard is retained for further evaluation. 
Table 3.4. Determination of ${ }^{235} U$ fissionable equivalent mass in the NTF facility tanks

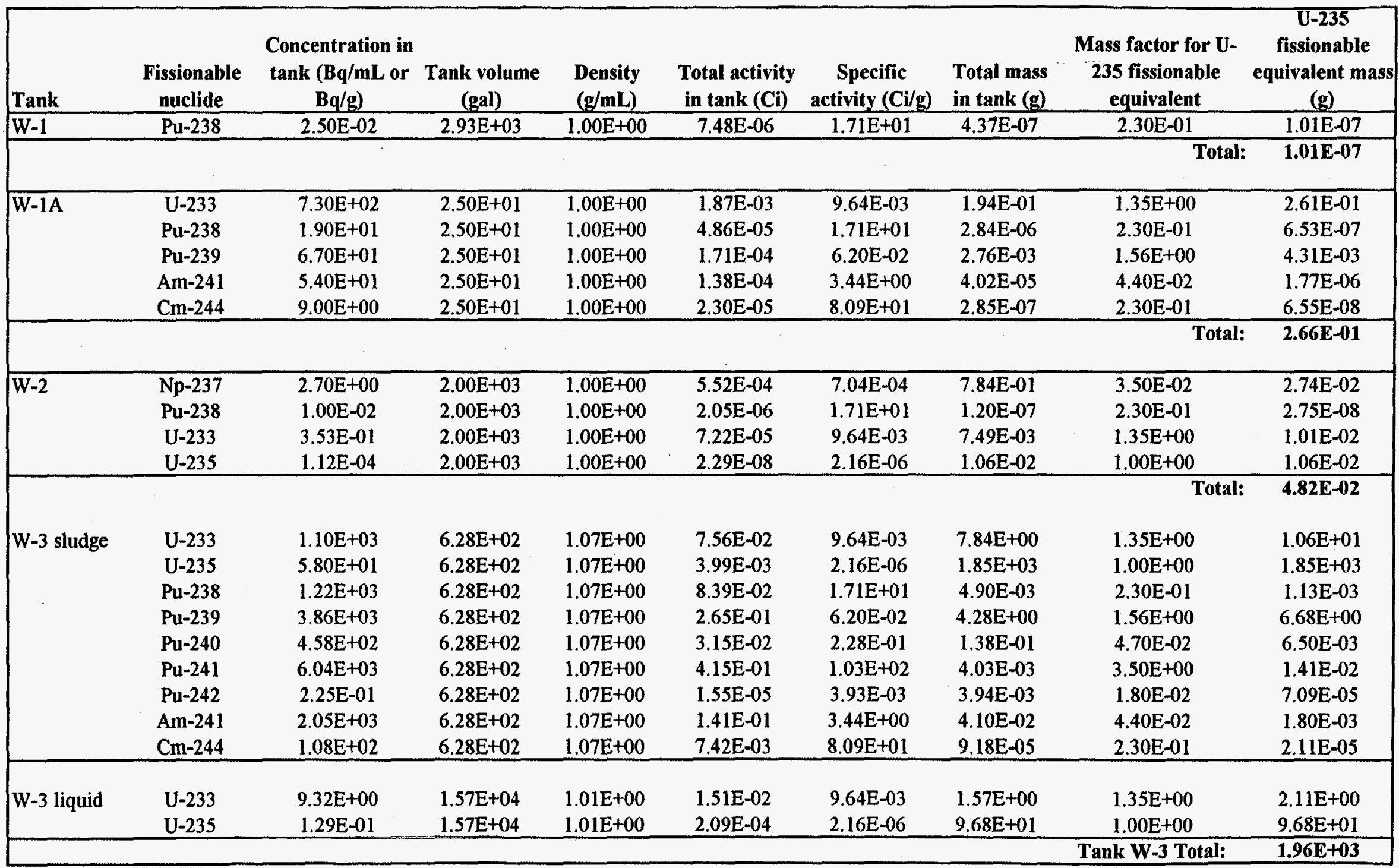


Table 3.4 (cont.)

\begin{tabular}{|c|c|c|c|c|c|c|c|c|c|}
\hline Tank & $\begin{array}{c}\begin{array}{c}\text { Fissionable } \\
\text { nuclide }\end{array} \\
\end{array}$ & $\begin{array}{c}\text { Concentration in } \\
\operatorname{tank}(\mathbf{B q} / \mathbf{m L} \text { or } \\
\mathbf{B q} / \mathbf{g}) \\
\end{array}$ & $\begin{array}{c}\text { Tank volume } \\
\text { (gal) } \\
\end{array}$ & $\begin{array}{l}\text { Density } \\
(\mathrm{g} / \mathrm{mL}) \\
\end{array}$ & $\begin{array}{l}\text { Total activity } \\
\text { in tank (Ci) }\end{array}$ & $\begin{array}{c}\text { Specific } \\
\text { activity (Ci/g) }\end{array}$ & $\begin{array}{l}\text { Total mass } \\
\text { in tank (g) }\end{array}$ & $\begin{array}{c}\text { Mass factor for U- } \\
\begin{array}{c}235 \text { fissionable } \\
\text { equivalent }\end{array} \\
\end{array}$ & $\begin{array}{c}U-235 \\
\text { fissionable } \\
\text { equivalent mass } \\
\text { (g) } \\
\end{array}$ \\
\hline \multirow[t]{8}{*}{ W-4 sludge } & $\mathrm{U}-233$ & $5.33 E+02$ & $1.31 \mathrm{E}+03$ & $1.28 \mathrm{E}+00$ & $9.16 \mathrm{E}-02$ & $9.64 \mathrm{E}-03$ & $9.50 \mathrm{E}+00$ & $1.35 \mathrm{E}+00$ & $1.28 \mathrm{E}+01$ \\
\hline & U-235 & $9.97 \mathrm{E}+01$ & $1.31 \mathrm{E}+03$ & $1.28 \mathrm{E}+00$ & $1.71 \mathrm{E}-02$ & $2.16 \mathrm{E}-06$ & $7.94 E+03$ & $1.00 \mathrm{E}+00$ & $7.94 E+03$ \\
\hline & $\mathrm{Pu}-238$ & $4.67 \mathrm{E}+02$ & $1.31 \mathrm{E}+03$ & $1.28 \mathrm{E}+00$ & $8.03 \mathrm{E}-02$ & $1.71 \mathrm{E}+01$ & $4.69 \mathrm{E}-03$ & $2.30 \mathrm{E}-01$ & $1.08 \mathrm{E}-03$ \\
\hline & Pu-239 & $7.96 \mathrm{E}+03$ & $1.31 \mathrm{E}+03$ & $1.28 \mathrm{E}+00$ & $1.37 \mathrm{E}+00$ & $6.20 \mathrm{E}-02$ & $2.21 \mathrm{E}+01$ & $1.56 \mathrm{E}+00$ & $3.44 \mathrm{E}+01$ \\
\hline & $\mathrm{Pu}-240$ & $9.50 \mathrm{E}+02$ & $1.31 \mathrm{E}+03$ & $1.28 \mathrm{E}+00$ & $1.63 \mathrm{E}-01$ & $2.28 \mathrm{E}-01$ & $7.17 \mathrm{E}-01$ & 4.70E-02 & $3.37 \mathrm{E}-02$ \\
\hline & $\mathrm{Pu}-241$ & $6.85 E+03$ & $1.31 E+03$ & $1.28 \mathrm{E}+00$ & $1.18 \mathrm{E}+00$ & $1.03 E+02$ & $1.14 \mathrm{E}-02$ & $3.50 \mathrm{E}+00$ & $4.00 \mathrm{E}-02$ \\
\hline & $\mathrm{Pu}-242$ & $2.10 \mathrm{E}-01$ & $1.31 E+03$ & $1.28 \mathrm{E}+00$ & $3.61 E-05$ & $3.93 E-03$ & $9.20 \mathrm{E}-03$ & $1.80 \mathrm{E}-02$ & $1.66 \mathrm{E}-04$ \\
\hline & $\mathrm{Cm}-244$ & $2.02 \mathrm{E}+02$ & $1.31 \mathrm{E}+03$ & $1.28 \mathrm{E}+00$ & $3.47 \mathrm{E}-02$ & $8.09 \mathrm{E}+01$ & $4.30 \mathrm{E}-04$ & $2.30 \mathrm{E}-01$ & $9.88 \mathrm{E}-05$ \\
\hline \multirow[t]{2}{*}{ W-4 liquid } & U-233 & $1.54 \mathrm{E}+00$ & $2.98 \mathrm{E}+04$ & $1.01 \mathrm{E}+00$ & $4.73 \mathrm{E}-03$ & $9.64 \mathrm{E}-03$ & $4.91 \mathrm{E}-01$ & $1.35 \mathrm{E}+00$ & $6.63 \mathrm{E}-01$ \\
\hline & U-235 & $5.97 \mathrm{E}-01$ & $2.98 \mathrm{E}+04$ & $1.01 \mathrm{E}+00$ & $1.84 \mathrm{E}-03$ & $2.16 \mathrm{E}-06$ & $8.50 \mathrm{E}+02$ & $1.00 E+00$ & $8.50 \mathrm{E}+02$ \\
\hline & & & & & & & & Tank W-4 Total: & $8.84 E+03$ \\
\hline \multirow[t]{3}{*}{$\mathrm{W}-13$} & $\mathrm{Pu}-238$ & $5.50 \mathrm{E}+02$ & $2.50 \mathrm{E}+01$ & $1.03 \mathrm{E}+00$ & $1.41 \mathrm{E}-03$ & $1.71 E+01$ & $8.22 \mathrm{E}-05$ & $2.30 \mathrm{E}-01$ & $1.89 \mathrm{E}-05$ \\
\hline & $\mathrm{Pu}-239$ & $6.90 \mathrm{E}+01$ & $2.50 \mathrm{E}+01$ & $1.03 \mathrm{E}+00$ & $1.76 \mathrm{E}-04$ & $6.20 \mathrm{E}-02$ & $2.85 \mathrm{E}-03$ & $1.56 \mathrm{E}+00$ & $4.44 \mathrm{E}-03$ \\
\hline & & & & & & & & Total: & $4.46 \mathrm{E}-03$ \\
\hline W-14 & None & & & & & & & & \\
\hline \multirow[t]{3}{*}{ W-15 } & Pu-238 & $2.50 \mathrm{E}+02$ & $2.50 \mathrm{E}+01$ & $1.08 \mathrm{E}+00$ & $6.39 \mathrm{E}-04$ & $1.71 \mathrm{E}+01$ & $3.74 \mathrm{E}-05$ & $2.30 \mathrm{E}-01$ & $8.60 \mathrm{E}-06$ \\
\hline & $\mathrm{Pu}-239$ & $6.30 \mathrm{E}+02$ & $2.50 \mathrm{E}+01$ & $1.08 \mathrm{E}+00$ & $1.61 E-03$ & $6.20 \mathrm{E}-02$ & $2.60 \mathrm{E}-02$ & $1.56 \mathrm{E}+00$ & $4.05 \mathrm{E}-02$ \\
\hline & & & & & & & & Total: & $4,05 E-02$ \\
\hline
\end{tabular}


Table 3.5. Tank W-1 inventory analysis

Tank W-1

\begin{tabular}{lll}
\cline { 1 - 1 } Supernate Volume & 2926 & gal \\
Density & 1.002 & $\mathrm{~g} / \mathrm{mL}$
\end{tabular}

\begin{tabular}{lcccccc} 
& $\begin{array}{c}95 \% \\
\text { Concentration } \\
(\mathrm{Bq} / \mathrm{g})\end{array}$ & $\begin{array}{c}\text { Total } \\
\text { Activity in } \\
\text { Tank }(\mathrm{Ci})\end{array}$ & $\begin{array}{c}40 \mathrm{CFR} 302.4 \\
\text { RQ }(\mathrm{Ci})\end{array}$ & $\begin{array}{c}\text { Fraction of } \\
\text { RQ }\end{array}$ & $\begin{array}{c}\text { FoE-STD-1027-92 } \\
\text { Category 3 TQ (Ci) }\end{array}$ & $\begin{array}{c}\text { Category } 3 \\
\text { TQ }\end{array}$ \\
\hline Nuclide & $3.68 \mathrm{E}+00$ & $1.10 \mathrm{E}-03$ & $1.00 \mathrm{E}+02$ & $1.10 \mathrm{E}-05$ & $1.00 \mathrm{E}+03$ & $1.10 \mathrm{E}-06$ \\
$\mathrm{H}-3$ & $2.08 \mathrm{E}+01$ & $6.24 \mathrm{E}-03$ & $1.00 \mathrm{E}+00$ & $6.24 \mathrm{E}-03$ & $6.00 \mathrm{E}+01$ & $1.04 \mathrm{E}-04$ \\
$\mathrm{Cs}-137 / \mathrm{Ba}-137 \mathrm{~m}$ & $1.80 \mathrm{E}+02$ & $5.40 \mathrm{E}-02$ & $1.00 \mathrm{E}-01$ & $5.40 \mathrm{E}-01$ & $1.60 \mathrm{E}+01$ & $3.37 \mathrm{E}-03$ \\
$\mathrm{Sr}-90$ & $2.50 \mathrm{E}-02$ & $7.50 \mathrm{E}-06$ & $1.00 \mathrm{E}-02$ & $7.50 \mathrm{E}-04$ & $6.20 \mathrm{E}-01$ & $1.21 \mathrm{E}-05$ \\
$\mathrm{Pu}-238$ & & & Summed Ratio: & $5.47 \mathrm{E}-01$ & Summed Ratio: & $3.49 \mathrm{E}-03$
\end{tabular}

Ref: ORNL/ER-365, Evaluation of Phase I and Phase II

Sampling and Analysis Data for the Gunite and Associated Tanks

at Oak Ridge National Laboratory, Oak Ridge, Tennessee,

March 1996.

Table 3.6. Tank W-1A inventory analysis

Tank W-1A

Supernate Volume $\quad 2.50 \mathrm{E}+01 \mathrm{gal}$

Density $\quad 1.00 \mathrm{E}+00 \mathrm{~g} / \mathrm{mL}$

\begin{tabular}{lcccccc} 
Nuclide & $\begin{array}{c}\text { Sample } \\
\text { Concentration } \\
(\mathrm{Bq} / \mathrm{mL})\end{array}$ & $\begin{array}{c}\text { Total Activity } \\
\text { in Tank (Ci) }\end{array}$ & $\begin{array}{c}40 \mathrm{CFR} 302.4 \\
\text { RQ }(\mathrm{Ci})\end{array}$ & $\begin{array}{c}\text { Fraction of } \\
\text { RQ }\end{array}$ & $\begin{array}{c}\text { FoE-STD-1027-92 } \\
\text { Category 3 TQ (Ci) }\end{array}$ & $\begin{array}{c}\text { Category } 3 \\
\text { TQ }\end{array}$ \\
\hline $\mathrm{Cs}-137$ & $1.40 \mathrm{E}+02$ & $3.58 \mathrm{E}-04$ & $1.00 \mathrm{E}+00$ & $3.58 \mathrm{E}-04$ & $6.00 \mathrm{E}+01$ & $5.97 \mathrm{E}-06$ \\
$\mathrm{C}-60$ & $4.40 \mathrm{E}+00$ & $1.13 \mathrm{E}-05$ & $1.00 \mathrm{E}+01$ & $1.13 \mathrm{E}-06$ & $2.80 \mathrm{E}+02$ & $4.02 \mathrm{E}-08$ \\
$\mathrm{Sr}-90$ & $3.20 \mathrm{E}+02$ & $8.18 \mathrm{E}-04$ & $1.00 \mathrm{E}-01$ & $8.18 \mathrm{E}-03$ & $1.6 \mathrm{EE}+01$ & $5.12 \mathrm{E}-05$ \\
$\mathrm{H}-3$ & $2.60 \mathrm{E}+00$ & $6.65 \mathrm{E}-06$ & $1.00 \mathrm{E}+02$ & $6.65 \mathrm{E}-08$ & $1.00 \mathrm{E}+03$ & $6.65 \mathrm{E}-09$ \\
$\mathrm{U}-233$ & $7.30 \mathrm{E}+02$ & $1.87 \mathrm{E}-03$ & $1.00 \mathrm{E}-01$ & $1.87 \mathrm{E}-02$ & $4.20 \mathrm{E}+00$ & $4.45 \mathrm{E}-04$ \\
$\mathrm{U}-238$ & $5.00 \mathrm{E}+00$ & $1.28 \mathrm{E}-05$ & $1.00 \mathrm{E}-01$ & $1.28 \mathrm{E}-04$ & $4.20 \mathrm{E}+00$ & $3.04 \mathrm{E}-06$ \\
$\mathrm{Pu}-238$ & $1.90 \mathrm{E}+01$ & $4.86 \mathrm{E}-05$ & $1.00 \mathrm{E}-02$ & $4.86 \mathrm{E}-03$ & $6.20 \mathrm{E}-01$ & $7.84 \mathrm{E}-05$ \\
$\mathrm{Pu}-239$ & $6.70 \mathrm{E}+01$ & $1.71 \mathrm{E}-04$ & $1.00 \mathrm{E}-02$ & $1.71 \mathrm{E}-02$ & $5.20 \mathrm{E}-01$ & $3.30 \mathrm{E}-04$ \\
$\mathrm{Cm}-244$ & $9.00 \mathrm{E}+00$ & $2.30 \mathrm{E}-05$ & $1.00 \mathrm{E}-02$ & $2.30 \mathrm{E}-03$ & $1.00 \mathrm{E}+00$ & $2.30 \mathrm{E}-05$ \\
Am-241 & $5.40 \mathrm{E}+01$ & $1.38 \mathrm{E}-04$ & $1.00 \mathrm{E}-02$ & $1.38 \mathrm{E}-02$ & $5.20 \mathrm{E}-01$ & $2.66 \mathrm{E}-04$ \\
$\mathrm{Cs}-134$ & $4.60 \mathrm{E}+00$ & $1.18 \mathrm{E}-05$ & $1.00 \mathrm{E}+00$ & $1.18 \mathrm{E}-05$ & $4.20 \mathrm{E}+01$ & $2.80 \mathrm{E}-07$ \\
$\mathrm{U}-232 *$ & $2.70 \mathrm{E}+02$ & $6.91 \mathrm{E}-04$ & $1.00 \mathrm{E}-02$ & $6.91 \mathrm{E}-02$ & $8.15 \mathrm{E}-01$ & $8.47 \mathrm{E}-04$ \\
\hline
\end{tabular}

* TQ determined based on ratio of dose conversion factors for U-232 and U-233 and Cat. 3 TQ

for U-233.

Ref: ORNL/ER-13, Sampling and Analysis of Inactive Waste Storage Tank Contents at ORNL,

September 1990. 
Table 3.7. Tank W-2 inventory analysis

Tank W-2

\begin{tabular}{lll}
\hline Supernate Volume & $2.00 \mathrm{E}+03$ & $\mathrm{gal}$ \\
Density & $1.00 \mathrm{E}+00$ & $\mathrm{~g} / \mathrm{mL}$
\end{tabular}

\begin{tabular}{lcccccc} 
& $\begin{array}{c}95 \% \\
\text { Concentration } \\
(\mathrm{Bq} / \mathrm{g})\end{array}$ & $\begin{array}{c}\text { Total Activity } \\
\text { in Tank (Ci) }\end{array}$ & $\begin{array}{c}\text { 40CFR302.4 } \\
\text { RQ (Ci) }\end{array}$ & $\begin{array}{c}\text { Fraction of } \\
\text { RQ }\end{array}$ & $\begin{array}{c}\text { DOE-STD-1027-92 } \\
\text { Category 3 TQ (Ci) }\end{array}$ & $\begin{array}{c}\text { Category } 3 \\
\text { TQ }\end{array}$ \\
\hline Huclide & $1.67 \mathrm{E}+00$ & $3.41 \mathrm{E}-04$ & $1.00 \mathrm{E}+02$ & $3.41 \mathrm{E}-06$ & $1.00 \mathrm{E}+03$ & $3.41 \mathrm{E}-07$ \\
$\mathrm{Cs}-137 / \mathrm{Ba}-137 \mathrm{~m}$ & $2.09 \mathrm{E}+01$ & $4.27 \mathrm{E}-03$ & $1.00 \mathrm{E}+00$ & $4.27 \mathrm{E}-03$ & $6.00 \mathrm{E}+01$ & $7.11 \mathrm{E}-05$ \\
Sr-90 & $1.90 \mathrm{E}+02$ & $3.88 \mathrm{E}-02$ & $1.00 \mathrm{E}-01$ & $3.88 \mathrm{E}-01$ & $1.60 \mathrm{E}+01$ & $2.42 \mathrm{E}-03$ \\
Np-237 & $2.70 \mathrm{E}+00$ & $5.51 \mathrm{E}-04$ & $1.00 \mathrm{E}-02$ & $5.51 \mathrm{E}-02$ & $4.20 \mathrm{E}-01$ & $1.31 \mathrm{E}-03$ \\
Pu-238 & $1.00 \mathrm{E}-02$ & $2.04 \mathrm{E}-06$ & $1.00 \mathrm{E}-02$ & $2.04 \mathrm{E}-04$ & $6.20 \mathrm{E}-01$ & $3.29 \mathrm{E}-06$ \\
$\mathrm{U}-233$ & $3.53 \mathrm{E}-01$ & $7.20 \mathrm{E}-05$ & $1.00 \mathrm{E}-01$ & $7.20 \mathrm{E}-04$ & $4.20 \mathrm{E}+00$ & $1.72 \mathrm{E}-05$ \\
$\mathrm{U}-234$ & $1.13 \mathrm{E}-02$ & $2.31 \mathrm{E}-06$ & $1.00 \mathrm{E}-01$ & $2.31 \mathrm{E}-05$ & $4.20 \mathrm{E}+00$ & $5.49 \mathrm{E}-07$ \\
$\mathrm{U}-235$ & $1.12 \mathrm{E}-04$ & $2.29 \mathrm{E}-08$ & $1.00 \mathrm{E}-01$ & $2.29 \mathrm{E}-07$ & $4.20 \mathrm{E}+00$ & $5.44 \mathrm{E}-09$ \\
$\mathrm{U}-236 *$ & $1.43 \mathrm{E}-04$ & $2.92 \mathrm{E}-08$ & $1.00 \mathrm{E}-01$ & $2.92 \mathrm{E}-07$ & $4.20 \mathrm{E}+00$ & $6.95 \mathrm{E}-09$ \\
$\mathrm{U}-238$ & $1.21 \mathrm{E}-03$ & $2.47 \mathrm{E}-07$ & $1.00 \mathrm{E}-01$ & $2.47 \mathrm{E}-06$ & $4.20 \mathrm{E}+00$ & $5.88 \mathrm{E}-08$ \\
\hline & & & Summed Ratio: & $4.48 \mathrm{E}-01$ & Summed Ratio: & $3.83 \mathrm{E}-03$
\end{tabular}

* TQ determined based on ratio of dose conversion factors for U-236 and U-235 and Cat. 3 TQ for U-235.

Ref: ORNL/ER-365, Evaluation of Phase I and Phase II Sampling and Analysis Data for the Gunite and Associated Tanks at Oak Ridge National Laboratory, Oak Ridge, Tennessee, March 1996. 


\section{Table 3.8. Tank W-3 inventory analysis}

Tank W-3

Supernate Volume Supernate Density

Sludge Volume

Sludge Density
$1.57 \mathrm{E}+04 \mathrm{gal}$

$1.01 \mathrm{E}+00 \mathrm{~g} / \mathrm{mL}$

$6.28 \mathrm{E}+02 \mathrm{gal}$

$1.07 \mathrm{E}+00 \mathrm{~g} / \mathrm{cc}$

\begin{tabular}{|c|c|c|c|c|c|c|c|c|c|}
\hline Nuclide & $\begin{array}{c}95 \% \text { Supernate } \\
\text { Concentration } \\
(\mathrm{Bq} / \mathrm{g}) \\
\end{array}$ & $\begin{array}{c}\text { Total } \\
\text { Supernate } \\
\text { Activity (Ci) } \\
\end{array}$ & $\begin{array}{c}95 \% \text { Sludge } \\
\text { Concentration } \\
(\mathrm{Bq} / \mathrm{g})\end{array}$ & $\begin{array}{l}\text { Total Sludge } \\
\text { Activity (Ci) } \\
\end{array}$ & $\begin{array}{c}\text { Total } \\
\text { Activity in } \\
\text { Tank (Ci) }\end{array}$ & $\begin{array}{c}40 \mathrm{CFR} \\
302.2 \mathrm{RQ} \\
(\mathrm{Ci}) \\
\end{array}$ & $\begin{array}{c}\text { Fraction } \\
\text { of RQ }\end{array}$ & $\begin{array}{l}\text { DOE-STD-1027-92 } \\
\text { Category } 3 \text { TQ (Ci) }\end{array}$ & $\begin{array}{c}\text { Fraction } \\
\text { of TQ }\end{array}$ \\
\hline $\mathrm{H}-3$ & $1.04 \mathrm{E}+00$ & $1.68 \mathrm{E}-03$ & $2.20 \mathrm{E}+00$ & $1.51 \mathrm{E}-04$ & $1.83 \mathrm{E}-03$ & $1.00 \mathrm{E}+02$ & $1.83 \mathrm{E}-05$ & $1.00 \mathrm{E}+03$ & $1.83 \mathrm{E}-06$ \\
\hline $\mathrm{Co}-60$ & $2.35 \mathrm{E}-01$ & $3.79 \mathrm{E}-04$ & $2.40 \mathrm{E}+01$ & $1.65 \mathrm{E}-03$ & $2.03 \mathrm{E}-03$ & $1.00 \mathrm{E}+01$ & $2.03 E-04$ & $2.80 \mathrm{E}+02$ & $7.25 \mathrm{E}-06$ \\
\hline Cs-137/Ba-137m & $1.16 \mathrm{E}+03$ & $1.87 E+00$ & $4.67 E+04$ & $3.21 E+00$ & $5.08 \mathrm{E}+00$ & $1.00 \mathrm{E}+00$ & $5.08 \mathrm{E}+00$ & $6.00 \mathrm{E}+01$ & $8.47 \mathrm{E}-02$ \\
\hline Eu-154 & & & $7.60 \mathrm{E}+01$ & $5.22 \mathrm{E}-03$ & $5.22 \mathrm{E}-03$ & $1.00 \mathrm{E}+01$ & $5.22 \mathrm{E}-04$ & $2.00 E+02$ & $2.61 \mathrm{E}-05$ \\
\hline Sr-90 & $7.52 \mathrm{E}+01$ & $1.21 E-01$ & $4.63 \mathrm{E}+05$ & $3.18 \mathrm{E}+01$ & $3.20 \mathrm{E}+01$ & $1.00 \mathrm{E}-01$ & $3.20 \mathrm{E}+02$ & $1.60 \mathrm{E}+01$ & $2.00 \mathrm{E}+00$ \\
\hline Am-241 & & & $2.05 E+03$ & $1.41 \mathrm{E}-01$ & $1.41 \mathrm{E}-01$ & $1.00 \mathrm{E}-02$ & $1.41 \mathrm{E}+01$ & $5.20 \mathrm{E}-01$ & $2.71 \mathrm{E}-01$ \\
\hline $\mathrm{Cm}-244^{* *}$ & & & $1.80 \mathrm{E}+02$ & $1.24 \mathrm{E}-02$ & $1.24 \mathrm{E}-02$ & $1.00 \mathrm{E}-02$ & $1.24 \mathrm{E}+00$ & $1.00 \mathrm{E}+00$ & $1.24 \mathrm{E}-02$ \\
\hline Cf-252 & & & & & & $1.00 \mathrm{E}-01$ & $0.00 \mathrm{E}+00$ & $3.20 \mathrm{E}+00$ & $0.00 \mathrm{E}+00$ \\
\hline U-233 & $9.32 \mathrm{E}+00$ & $1.50 \mathrm{E}-02$ & $1.10 E+03$ & $7.56 \mathrm{E}-02$ & $9.07 \mathrm{E}-02$ & $1.00 \mathrm{E}-01$ & $9.07 \mathrm{E}-01$ & $4.20 \mathrm{E}+00$ & $2.16 \mathrm{E}-02$ \\
\hline U-234 & $3.30 \mathrm{E}+00$ & $5.33 \mathrm{E}-03$ & $1.37 \mathrm{E}+03$ & $9.42 \mathrm{E}-02$ & $9.95 E-02$ & $1.00 \mathrm{E}-01$ & $9.95 \mathrm{E}-01$ & $4.20 \mathrm{E}+00$ & $2.37 \mathrm{E}-02$ \\
\hline U-235 & $1.29 \mathrm{E}-01$ & $2.08 \mathrm{E}-04$ & $5.80 \mathrm{E}+01$ & $3.99 \mathrm{E}-03$ & $4.20 \mathrm{E}-03$ & $1.00 \mathrm{E}-01$ & $4.20 \mathrm{E}-02$ & $4.20 \mathrm{E}+00$ & $9.99 \mathrm{E}-04$ \\
\hline U-236 & $1.85 \mathrm{E}-02$ & $2.99 \mathrm{E}-05$ & $2.84 E+00$ & $1.95 \mathrm{E}-04$ & $2.25 \mathrm{E}-04$ & $1.00 \mathrm{E}-01$ & $2.25 \mathrm{E}-03$ & $4.20 \mathrm{E}+00$ & $5.36 \mathrm{E}-05$ \\
\hline U-238 & $3.20 \mathrm{E}+00$ & $5.17 \mathrm{E}-03$ & $1.41 \mathrm{E}+03$ & $9.69 \mathrm{E}-02$ & $1.02 \mathrm{E}-01$ & $1.00 \mathrm{E}-01$ & $1.02 \mathrm{E}+00$ & $4.20 \mathrm{E}+00$ & $2.43 \mathrm{E}-02$ \\
\hline Pu-238 & & & $1.22 \mathrm{E}+03$ & $8.39 \mathrm{E}-02$ & $8.39 \mathrm{E}-02$ & $1.00 \mathrm{E}-02$ & $8.39 E+00$ & $6.20 \mathrm{E}-01$ & $1.35 \mathrm{E}-01$ \\
\hline Pu.239 & & & $3.86 E+03$ & $2.65 \mathrm{E}-01$ & $2.65 \mathrm{E}-01$ & $1.00 \mathrm{E}-02$ & $2.65 \mathrm{E}+01$ & $5.20 \mathrm{E}-01$ & $5.10 \mathrm{E}-01$ \\
\hline $\mathrm{Pu}-240^{* *}$ & & & $4.58 \mathrm{E}+02$ & $3.15 \mathrm{E}-02$ & $3.15 E-02$ & $1.00 \mathrm{E}-02$ & $3.15 E+00$ & $5.20 \mathrm{E}-01$ & $6.06 \mathrm{E}-02$ \\
\hline Pu-241 & & & $6.04 \mathrm{E}+03$ & 4.15E-01 & $4.15 \mathrm{E}-01$ & $1.00 \mathrm{E}+00$ & $4.15 \mathrm{E}-01$ & $3.20 \mathrm{E}+01$ & $1.30 \mathrm{E}-02$ \\
\hline Pu-242** & & & $2.25 \mathrm{E}-01$ & $1.55 \mathrm{E}-05$ & $1.55 \mathrm{E}-05$ & $1.00 \mathrm{E}-02$ & $1.55 \mathrm{E}-03$ & $6.20 \mathrm{E}-01$ & $2.49 \mathrm{E}-05$ \\
\hline Pu-244** & & & & & & $1.00 \mathrm{E}-02$ & $0.00 \mathrm{E}+00$ & $6.20 \mathrm{E}-01$ & $0.00 \mathrm{E}+00$ \\
\hline
\end{tabular}

- TQ determined based on ratio of dose conversion factors for U-236 and U-235 and Cat. 3 TQ for U-235.

** TQ taken from information Ray Schwartz provided to Mitt Kreger dated 3-26-93. (Engineering Transmittal XSSE-653 dated 10-29-94, PRN X1993-0066.)

Ref: ORNL/ER-365, Evaluation of Phase I and Phase II

Sampling and Analysis Data for the Gunite and Associated Tanks at Oak Ridge National Laboratory, Oak Ridge, Tennessee, March 1996. 
Table 3.9. Tank W-4 inventory analysis

Tank W-4

Supernate Volume Supernate Density Sludge Volume Sludge Density

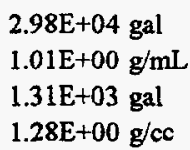

\begin{tabular}{|c|c|c|c|c|c|c|c|c|c|}
\hline Nuclide & $\begin{array}{c}95 \% \text { Supernate } \\
\text { Concentration } \\
(\mathrm{Bq} / \mathrm{g})\end{array}$ & $\begin{array}{c}\text { Total } \\
\text { Supernate } \\
\text { Activity (Ci) }\end{array}$ & $\begin{array}{c}95 \% \text { Sludge } \\
\text { Concentration } \\
(\mathrm{Bg} / \mathrm{g})\end{array}$ & $\begin{array}{l}\text { Total Sludge } \\
\text { Activity (Ci) }\end{array}$ & $\begin{array}{c}\text { Total } \\
\text { Activity in } \\
\text { Tank (Ci) }\end{array}$ & $\begin{array}{c}40 \text { CFR } \\
302.2 \mathrm{RQ} \\
\text { (Ci) }\end{array}$ & $\begin{array}{c}\text { Fraction } \\
\text { of } R Q\end{array}$ & $\begin{array}{l}\text { DOE-STD-1027-92 } \\
\text { Category } 3 \text { TQ (Ci) }\end{array}$ & $\begin{array}{c}\text { Fraction } \\
\text { of TQ }\end{array}$ \\
\hline$\overline{\mathrm{H}-3}$ & $2.79 \mathrm{E}+00$ & $8.56 \mathrm{E}-03$ & $2.78 \mathrm{E}+00$ & $4.78 \mathrm{E}-04$ & $9.04 \mathrm{E}-03$ & $1.00 \mathrm{E}+02$ & $9.04 E-05$ & $1.00 \mathrm{E}+03$ & $9.04 \mathrm{E}-06$ \\
\hline $\operatorname{Co} 60$ & $1.28 \mathrm{E}+02$ & $3.93 \mathrm{E}-01$ & $1.20 \mathrm{E}+01$ & $2.06 \mathrm{E}-03$ & $3.95 E-01$ & $1.00 E+01$ & $3.95 \mathrm{E}-02$ & $2.80 \mathrm{E}+02$ & 1.41E-03 \\
\hline $\mathrm{Cs}-137 / \mathrm{Ba}-137 \mathrm{~m}$ & $1.58 \mathrm{E}+04$ & $4.85 \mathrm{E}+01$ & $2.69 \mathrm{E}+05$ & $4.63 E+01$ & $9.47 \mathrm{E}+01$ & $1.00 \mathrm{E}+00$ & $9.47 \mathrm{E}+01$ & $6.00 \mathrm{E}+01$ & $1.58 \mathrm{E}+00$ \\
\hline Eu-154 & & & & $0.00 \mathrm{E}+00$ & $0.00 \mathrm{E}+00$ & $1.00 \mathrm{E}+01$ & $0.00 E+00$ & $2.00 \mathrm{E}+02$ & $0.00 \mathrm{E}+00$ \\
\hline Sr-90 & $2.97 \mathrm{E}+03$ & $9.11 \mathrm{E}+00$ & $2.11 \mathrm{E}+05$ & $3.63 \mathrm{E}+01$ & $4.54 \mathrm{E}+01$ & $1.00 \mathrm{E}-01$ & $4.54 \mathrm{E}+02$ & $1.60 \mathrm{E}+01$ & $2.84 \mathrm{E}+00$ \\
\hline Am-241 & & & & $0.00 \mathrm{E}+00$ & $0.00 \mathrm{E}+00$ & $1.00 \mathrm{E}-02$ & $0.00 \mathrm{E}+00$ & $5.20 \mathrm{E}-01$ & $0.00 \mathrm{E}+00$ \\
\hline $\mathrm{Cm}-244^{* *}$ & & & $2.02 \mathrm{E}+02$ & $3.47 \mathrm{E}-02$ & $3.47 \mathrm{E}-02$ & $1.00 E-02$ & $3.47 \mathrm{E}+00$ & $1.00 \mathrm{E}+00$ & $3.47 \mathrm{E}-02$ \\
\hline Cf-252 & & & $6.84 \mathrm{E}+00$ & $1.18 E-03$ & $1.18 \mathrm{E}-03$ & $1.00 \mathrm{E}-01$ & $1.18 \mathrm{E}-02$ & $3.20 \mathrm{E}+00$ & $3.68 \mathrm{E}-04$ \\
\hline $\mathrm{U}-233$ & $1.54 \mathrm{E}+00$ & 4.73E-03 & $5.33 E+02$ & $9.16 \mathrm{E}-02$ & $9.64 \mathrm{E}-02$ & $1.00 \mathrm{E}-01$ & $9.64 \mathrm{E}-01$ & $4.20 \mathrm{E}+00$ & $2.29 \mathrm{E}-02$ \\
\hline U-234 & $1.47 E+01$ & $4.51 \mathrm{E}-02$ & $2.58 E+03$ & $4.44 \mathrm{E}-01$ & $4.89 \mathrm{E}-01$ & $1.00 \mathrm{E}-01$ & $4.89 \mathrm{E}+00$ & $4.20 \mathrm{E}+00$ & $1.16 \mathrm{E}-01$ \\
\hline U-235 & 5.97E-01 & $1.83 E-03$ & $9.97 \mathrm{E}+01$ & $1.71 E-02$ & $1.90 \mathrm{E}-02$ & $1.00 E-01$ & $1.90 \mathrm{E}-01$ & $4.20 E+00$ & $4.52 \mathrm{E}-03$ \\
\hline U-236* & $7.47 \mathrm{E}-02$ & $2.29 \mathrm{E}-04$ & $5.60 \mathrm{E}+00$ & $9.63 E-04$ & $1.19 \mathrm{E}-03$ & $1.00 \mathrm{E}-01$ & $1.19 \mathrm{E}-02$ & $4.20 \mathrm{E}+00$ & $2.84 \mathrm{E}-04$ \\
\hline U-238 & $1.49 \mathrm{E}+01$ & 4.57E-02 & $2.43 E+03$ & $4.18 \mathrm{E}-01$ & $4.64 E-01$ & $1.00 \mathrm{E}-01$ & $4.64 \mathrm{E}+00$ & $4.20 \mathrm{E}+00$ & $1.10 \mathrm{E}-01$ \\
\hline Pu-238 & $7.56 \mathrm{E}-02$ & $2.32 \mathrm{E}-04$ & $4.67 E+02$ & $8.03 E-02$ & $8.05 E-02$ & $1.00 \mathrm{E}-02$ & $8.05 E+00$ & $6.20 \mathrm{E}-01$ & $1.30 \mathrm{E}-01$ \\
\hline Pu-239 & & & $7.96 \mathrm{E}+03$ & $1.37 \mathrm{E}+00$ & $1.37 \mathrm{E}+00$ & $1.00 E-02$ & $1.37 \mathrm{E}+02$ & $5.20 \mathrm{E}-01$ & $2.63 \mathrm{E}+00$ \\
\hline $\mathrm{Pu}-240^{* *}$ & & & $9.50 \mathrm{E}+02$ & $1.63 E-01$ & $1.63 \mathrm{E}-01$ & $1.00 \mathrm{E}-02$ & $1.63 E+01$ & $5.20 \mathrm{E}-01$ & 3.14E-01 \\
\hline Pu-24I & & & $6.85 E+03$ & $1.18 \mathrm{E}+00$ & $1.18 \mathrm{E}+00$ & $1.00 \mathrm{E}+00$ & $1.18 \mathrm{E}+00$ & $3.20 \mathrm{E}+01$ & $3.68 \mathrm{E}-02$ \\
\hline Pu-242** & $1.00 \mathrm{E}+02$ & $3.07 \mathrm{E}-01$ & $2.10 \mathrm{E}-01$ & $3.61 \mathrm{E}-0 \mathrm{~S}$ & $3.07 \mathrm{E}-01$ & $1.00 \mathrm{E}-02$ & $3.07 \mathrm{E}+01$ & $6.20 \mathrm{E}-01$ & $4.95 \mathrm{E}-01$ \\
\hline $\mathrm{Pu}-244^{* *}$ & & & $2.51 E-06$ & $4.32 \mathrm{E}-10$ & 4.32E-10 & $1.00 \mathrm{E}-02$ & $4.32 \mathrm{E}-08$ & $6.20 \mathrm{E}-01$ & $6.96 \mathrm{E}-10$ \\
\hline
\end{tabular}

- TQ determined based on ratio of dose conversion factors for U-236 and U-235 and Cat. 3 TQ for U-235.

** TQ taken from information Ray Schwartz provided to Milt Kreger dated 3-26-93. (Engineering Transmittal XSSE-653 dated 10-29-94, PRN X1993-0066.)

Ref: ORNL/ER-365, Evaluation of Phase I and Phase II

Sampling and Analysis Data for the Gunite and Associated Tanks at Oak Ridge National Laboratory, Oak Ridge, Tennessee, March 1996. 
Table 3.10. Tank $W-13$ inventory analysis

Tank W-13

\begin{tabular}{ll}
\hline Supernate Volume & $2.50 \mathrm{E}+01 \mathrm{gal}$ \\
Density & $1.03 \mathrm{E}+00 \mathrm{~g} / \mathrm{mL}$
\end{tabular}

\begin{tabular}{lcccccc} 
& $\begin{array}{c}\text { Sample } \\
\text { Concentration } \\
(\mathrm{Bq} / \mathrm{mL})\end{array}$ & $\begin{array}{c}\text { Total } \\
\text { Activity in } \\
\text { Tank (Ci) }\end{array}$ & $\begin{array}{c}40 \mathrm{CFR} 302.4 \mathrm{RQ} \\
(\mathrm{Ci})\end{array}$ & $\begin{array}{c}\text { Fraction of } \\
\text { RQ }\end{array}$ & $\begin{array}{c}\text { DOE-STD-1027-92 } \\
\text { Category 3 TQ (Ci) }\end{array}$ & $\begin{array}{c}\text { Fraction of } \\
\text { Category 3 } \\
\text { TQ }\end{array}$ \\
\hline $\mathrm{Cs}-137$ & $6.10 \mathrm{E}+05$ & $1.56 \mathrm{E}+00$ & $1.00 \mathrm{E}+00$ & $1.56 \mathrm{E}+00$ & $6.00 \mathrm{E}+01$ & $2.60 \mathrm{E}-02$ \\
$\mathrm{C}-60$ & $1.90 \mathrm{E}+02$ & $4.86 \mathrm{E}-04$ & $1.00 \mathrm{E}+01$ & $4.86 \mathrm{E}-05$ & $2.80 \mathrm{E}+02$ & $1.74 \mathrm{E}-06$ \\
$\mathrm{Sr}-90$ & $5.90 \mathrm{E}+05$ & $1.51 \mathrm{E}+00$ & $1.00 \mathrm{E}-01$ & $1.51 \mathrm{E}+01$ & $1.60 \mathrm{E}+01$ & $9.43 \mathrm{E}-02$ \\
$\mathrm{H}-3$ & $2.80 \mathrm{E}+03$ & $7.16 \mathrm{E}-03$ & $1.00 \mathrm{E}+02$ & $7.16 \mathrm{E}-05$ & $1.00 \mathrm{E}+03$ & $7.16 \mathrm{E}-06$ \\
$\mathrm{Pu}-238$ & $5.50 \mathrm{E}+02$ & $1.41 \mathrm{E}-03$ & $1.00 \mathrm{E}-02$ & $1.41 \mathrm{E}-01$ & $6.20 \mathrm{E}-01$ & $2.27 \mathrm{E}-03$ \\
$\mathrm{Pu}-239$ & $6.90 \mathrm{E}+01$ & $1.76 \mathrm{E}-04$ & $1.00 \mathrm{E}-02$ & $1.76 \mathrm{E}-02$ & $5.20 \mathrm{E}-01$ & $3.39 \mathrm{E}-04$ \\
Th-228/Th-232 & $1.30 \mathrm{E}+02$ & $3.33 \mathrm{E}-04$ & $1.00 \mathrm{E}-03$ & $3.33 \mathrm{E}-01$ & $1.00 \mathrm{E}-01$ & $3.33 \mathrm{E}-03$ \\
Eu-154 & $1.60 \mathrm{E}+03$ & $4.09 \mathrm{E}-03$ & $1.00 \mathrm{E}+01$ & $4.09 \mathrm{E}-04$ & $2.00 \mathrm{E}+02$ & $2.05 \mathrm{E}-05$ \\
\hline & & & Summed Ratio: & $1.71 \mathrm{E}+01$ & Summed Ratio: & $1.26 \mathrm{E}-01$
\end{tabular}

Ref: ORNL/ER-13, Sampling and Analysis of Inactive Waste Storage Tank Contents at ORNL, September 1990.

Table 3.11. Tank $W-14$ inventory analysis

Tank W-14

Supernate Volume

$2.50 \mathrm{E}+01 \mathrm{gal}$

Density $1.05 \mathrm{E}+00 \mathrm{~g} / \mathrm{mL}$

\begin{tabular}{lcccccc} 
& $\begin{array}{c}\text { Sample } \\
\text { Concentration } \\
\text { Nuclide }\end{array}$ & $\begin{array}{c}\text { Total Activity in } \\
\text { Tank }(\mathrm{Ci})\end{array}$ & $\begin{array}{c}40 \mathrm{CFR} 302.4 \\
\text { RQ }(\mathrm{Ci})\end{array}$ & Fraction of RQ & $\begin{array}{c}\text { DOE-STD-1027-92 } \\
\text { Category 3 TQ (Ci) }\end{array}$ & $\begin{array}{c}\text { Fraction of } \\
\text { Category } 3 \\
\text { TQ }\end{array}$ \\
\hline Cs-137 & $4.10 \mathrm{E}+05$ & $1.05 \mathrm{E}+00$ & $1.00 \mathrm{E}+00$ & $1.05 \mathrm{E}+00$ & $6.00 \mathrm{E}+01$ & $1.75 \mathrm{E}-02$ \\
$\mathrm{Co}-60$ & $1.10 \mathrm{E}+03$ & $2.81 \mathrm{E}-03$ & $1.00 \mathrm{E}+01$ & $2.81 \mathrm{E}-04$ & $2.80 \mathrm{E}+02$ & $1.00 \mathrm{E}-05$ \\
$\mathrm{Sr}-90$ & $4.30 \mathrm{E}+05$ & $1.10 \mathrm{E}+00$ & $1.00 \mathrm{E}-01$ & $1.10 \mathrm{E}+01$ & $1.60 \mathrm{E}+01$ & $6.87 \mathrm{E}-02$ \\
$\mathrm{H}-3$ & $3.00 \mathrm{E}+00$ & $7.67 \mathrm{E}-06$ & $1.00 \mathrm{E}+02$ & $7.67 \mathrm{E}-08$ & $1.00 \mathrm{E}+03$ & $7.67 \mathrm{E}-09$ \\
Th-228/Th-232 & $8.00 \mathrm{E}+03$ & $2.05 \mathrm{E}-02$ & $1.00 \mathrm{E}-03$ & $2.05 \mathrm{E}+01$ & $1.00 \mathrm{E}-01$ & $2.05 \mathrm{E}-01$ \\
\hline & & & Summed Ratio: & $3.25 \mathrm{E}+01$ & Summed Ratio: & $2.91 \mathrm{E}-01$
\end{tabular}

Ref: ORNL/ER-13, Sampling and Analysis of Inactive Waste Storage Tank Contents at ORNL, September 1990. 
Table 3.12. Tank W-15 inventory analysis

Tank W-15

\begin{tabular}{ll}
\hline Supernate Volume & $\begin{array}{l}2.50 \mathrm{E}+01 \mathrm{gal} \\
\text { Density }\end{array}$ \\
$1.08 \mathrm{E}+00 \mathrm{~g} / \mathrm{mL}$
\end{tabular}

Sample

Concentration Total Activity 40CFR302.4

Nuclide

Cs-137

Co-60

Sr-90

$\mathrm{H}-3$

U-233

Pu-238

Pu-239

Th-228/Th-232 $(\mathrm{Bq} / \mathrm{mL})$

$1.60 \mathrm{E}+06$

$1.40 \mathrm{E}+03$

$1.70 \mathrm{E}+06$

$3.20 \mathrm{E}+01$

$1.40 \mathrm{E}+02$

$2.50 \mathrm{E}+02$

$6.30 \mathrm{E}+02$

$1.50 \mathrm{E}+03$ in Tank (Ci)

RQ (Ci)

$4.09 \mathrm{E}+00$

$3.58 \mathrm{E}-03$

$4.35 \mathrm{E}+00$

8.18E-05

$3.58 \mathrm{E}-04$

6.39E-04

$1.61 \mathrm{E}-03$

$3.84 \mathrm{E}-03$

$1.00 \mathrm{E}+00$

$1.00 \mathrm{E}+01$

$1.00 \mathrm{E}-01$

$1.00 \mathrm{E}+02$

$1.00 \mathrm{E}-01$

$1.00 \mathrm{E}-02$

$1.00 \mathrm{E}-02$

$1.00 \mathrm{E}-03$

Summed Ratio:

DO

Fraction of RQ

$4.09 \mathrm{E}+00$

3.58E-04

$4.35 \mathrm{E}+01$

$8.18 \mathrm{E}-07$

$3.58 \mathrm{E}-03$

$6.39 \mathrm{E}-02$

$1.61 \mathrm{E}-01$

$3.84 \mathrm{E}+00$

$5.16 \mathrm{E}+01$
Fraction of

DOE-STD-1027-92 Category 3 Category $3 \mathrm{TQ}(\mathrm{Ci})$ TQ

$6.82 \mathrm{E}-02$

$1.28 \mathrm{E}-05$

$2.72 \mathrm{E}-01$

$8.18 \mathrm{E}-08$

8.53E-05

$1.03 \mathrm{E}-03$

$6.20 \mathrm{E}-01$

$3.10 \mathrm{E}-03$

$5.20 \mathrm{E}-01$

$3.84 \mathrm{E}-02$ 1.00E-01

Summed Ratio: 3.83E-01

Ref: ORNL/ER-13, Sampling and Analysis of Inactive Waste Storage Tank Contents at ORNL, September 1990.

Table 3.13. Determination of ${ }^{235} \mathrm{U}$ fissionable equivalent mass in Tank $\mathrm{W}-11$

\begin{tabular}{|c|c|c|c|c|c|c|}
\hline Tank & $\begin{array}{c}\text { Fissionable } \\
\text { nuclide }\end{array}$ & $\begin{array}{l}\text { Total activity } \\
\text { in tank (Ci) }\end{array}$ & $\begin{array}{c}\text { Specific } \\
\text { activity }(\mathrm{Ci} / \mathrm{g})\end{array}$ & $\begin{array}{l}\text { Total mass } \\
\text { in tank (g) }\end{array}$ & $\begin{array}{c}\text { Mass factor for U- } \\
235 \text { fissionable } \\
\text { equivalent }\end{array}$ & $\begin{array}{c}\mathrm{U}-235 \\
\text { fissionable } \\
\text { equivalent mass } \\
\text { (g) }\end{array}$ \\
\hline \multirow[t]{3}{*}{$\bar{W}-11$} & U-233 & $4.35 \mathrm{E}-07$ & $9.64 \mathrm{E}-03$ & $4.51 \mathrm{E}-05$ & $1.35 \mathrm{E}+00$ & $6.09 \mathrm{E}-05$ \\
\hline & U-235 & $6.96 \mathrm{E}-08$ & $2.16 \mathrm{E}-06$ & $3.22 \mathrm{E}-02$ & $1.00 \mathrm{E}+00$ & $3.22 \mathrm{E}-02$ \\
\hline & $\mathrm{Pu}-238$ & $2.83 \mathrm{E}-07$ & $1.71 \mathrm{E}+01$ & $1.65 \mathrm{E}-08$ & $2.30 \mathrm{E}-01$ & $3.80 \mathrm{E}-09$ \\
\hline
\end{tabular}


Toxic/corrosive/reactive materials are present in all of the NTF tanks. Comparison of the chemical constituents of the liquids to regulatory limits contained in 40 CFR $302.4^{5}$ is difficult because discrete chemicals are not easily distinguished by sampling. It is important to consider the intent of the regulatory limits. The RQ values listed in 40 CFR $302.4^{5}$ are intended to identify facilities and processes with toxic material hazards that can have significant toxic consequences to on-site and off-site personnel during and following accidents. Most RQs are based on a pure chemical form that is susceptible to airborne release when spilled, heated, or ignited. The chemicals present in the liquids in the NTF tanks are in aqueous solution and are not susceptible to cloud-type releases.

The lowest listed RQ for hazardous chemicals is $1 \mathrm{lb}$. Based on the volume of liquid present in each tank, the concentration of a hazardous chemical necessary to exceed $1 \mathrm{lb}$ is determined and compared to sampling data. This screening process is documented in calc-note DAC-PX446G01-SSE-002. ${ }^{6}$ It was determined that Tanks W-1A, W-13, W-14, and W-15 do not contain quantities of material which exceed the RQ values in 40 CFR $302.4 .^{5}$ The toxic/corrosive/reactive material hazard for these tanks is screened from further consideration. The calc-note further determined that $R Q$ values may be exceeded by the materials present in Tanks W-1, W-2, W-3, and W-4. The toxic/corrosive/reactive material hazard for these tanks is not screened out and is retained for further analysis.

Flammable materials are present in trace quantities in the liquid in the NTF tanks. The screening criterion for flammable materials from ES/CSET-2/R2 $2^{4}$ is $5000 \mathrm{lb}$ of liquid with a flashpoint $<100^{\circ} \mathrm{F}$. None of the flammable materials identified during sampling are present in quantities that exceed the screening criterion. Therefore, the flammable materials hazard is screened out and is not retained for further consideration.

The electrical and potential energy hazards that are present in the NTF facility tanks are electric power for lighting and instrumentation, steam for steam jets, and compressed air for instrumentation. These are all considered routine hazards and are not retained for further consideration.

\subsubsection{Preliminary hazard classification}

Tables 3.5 through 3.12 list the facility inventories, based on sampling, of the NTF facility tanks and compare the facility inventories with the RQs from 40 CFR $302.4^{5}$ and the Category 3 TQs from DOE-STD-1027-92. 'The summed ratios of the individual isotope inventories to the RQs and TQs are shown on each table. The RQ summed ratios for Tanks W-1, W-1A, and W-2 are less than 1.0, indicating that the tank inventories do not exceed the RQs. Therefore, the nuclear facility classification for these tanks is Industrial. The Category 3 summed ratios for Tanks W-13, W-14, and W-15 are less than 1.0, indicating that the tank inventories do not exceed the Category $3 \mathrm{TQ}$. Therefore, the nuclear facility classification for these tanks is Radiological. The Category 3 TQ summed ratios for Tanks W-3 and W-4 exceed 1.0. The inventory for Tanks W-3 and W-4 are compared to the Category 2 TQs. The summed ratios of the individual isotope inventories to the Category 2 TQs are less than 1.0 for both tanks. Therefore, the preliminary nuclear facility classification for Tanks W-3 and W-4 is Category 3 .

In Sect. 3.3.1.1, the toxic/corrosive/reactive material inventories for Tanks W-1A, W-13, W-14, and W-15 were shown to be below RQ values listed in 40 CFR 302.4. ${ }^{5}$ Therefore, the toxic material hazard is screened out and the non-nuclear facility hazard classification for these tanks is "Industrial." The toxic material inventories for Tanks W-1, W-2, W-3 and W-4 could not be shown to be below RQ values listed in 40 CFR $302.4 .^{5}$ A consequence analysis in calc-note DAC-PX446G01-SSE-002 ${ }^{6}$ indicates that the release of toxic material from credible accident scenarios results in "Negligible" consequence to both on-site and off-site receptors. The consequence calculation assumed a release fraction 1E-04, which is for simple spills at pressures up to $200 \mathrm{psig}^{10}, 30$ meters to the receptor and a 
bounding sludge/supernate release rate of $100 \mathrm{gpm}$. Therefore, the non-nuclear facility hazard classification for Tanks W-1, W-2, W-3, and W-4 is "Industrial."

\subsubsection{Tank W-11}

\subsubsection{Hazard identification}

The hazard identification table for Tank W-11 is included as Appendix B. The hazards identified for Tank W-11 include fissionable materials, radiation sources, toxic/corrosive/reactive materials, flammable materials, and electrical energy sources. Fissionable materials are present in the tank as various isotopes of uranium and plutonium. Table 3.13 lists the fissionable materials present and calculates the ${ }^{235} \mathrm{U}$ fissionable equivalent mass in the tank. Tank W-11 contains amounts of fissionable materials that are well below the fissionable material control limit for ${ }^{235} \mathrm{U}$ of $250 \mathrm{~g}$. Therefore, an inadvertent criticality accident is not credible for Tank W-11. The fissionable material hazard is screened out and is not retained for further evaluation.

Radioactive materials are present in Tank W-11. Table 3.14 lists the best estimate of the inventory present in Tank W-11 and compares the inventory to the RQ values in 40 CFR 302.4. ${ }^{5}$ The inventory in Tank W-11 does not exceed RQ values and therefore is not considered to present a significant risk to on-site or off-site personnel. The radiation source hazard is screened out from further consideration.

Toxic/corrosive/reactive materials are present in Tank W-11. A screening analysis of the hazardous material inventory in Tank W-11 was conducted similar to that described in Sect. 3.3.1.1 and documented in calc-note DAC-PX446G01-SSE-002. It was determined that the inventory in Tank W-11 does not exceed the screening RQ value. Therefore, the toxic/corrosive/reactive material hazard is screened out and is not evaluated further.

Flammable materials are present in trace quantities in the liquid in Tank W-11. The screening criterion for flammable materials from ES/CSET-2/R2 $2^{4}$ is $5000 \mathrm{lb}$ of liquid with a flashpoint $<100^{\circ} \mathrm{F}$. None of the flammable materials identified during sampling are present in quantities that exceed the screening criterion. Therefore, the flammable materials hazard is screened out and is not retained for further consideration.

The electrical energy hazard that is present at Tank W-11 is electric power for lighting and instrumentation. These are all considered routine hazards and are not retained for further consideration.

\subsubsection{Preliminary hazard classification}

Table 3.14 lists the inventory of Tank W-11 and compares the inventory to RQs from 40 CFR $302.4^{5}$ and the Category 3 TQs from DOE-STD-1027-92. ${ }^{1}$ The summed ratios of the individual isotope inventories to the RQs and TQs are shown. The RQ summed ratio for Tank W-11 is less than 1.0 , indicating that the tank inventory does not exceed the RQ values. Therefore, the nuclear facility classification for Tank W-11 is Industrial.

The non-nuclear facility classification is determined in calc-note DAC-PX446G01-SSE-002. ${ }^{6}$ The non-nuclear facility classification of Tank W-11 was determined to be Industrial. 
Table 3.14. Tank W-11 radioactive material inventory analysis

Tank W-11

Supernate Volume

Supernate Density

$\begin{array}{rr}722 & \text { gal } \\ 0.996 & \mathrm{~g} / \mathrm{mL}\end{array}$

DOE-STD-1027

Total Activity in $\quad$ 40CFR302.4 RQ Supernate $(95 \% \mathrm{Ci})$

(Ci)

$1.00 \mathrm{E}+02$

$1.00 \mathrm{E}+01$

$1.00 \mathrm{E}+00$

$1.00 \mathrm{E}-01$

$1.00 \mathrm{E}-02$

$1.00 \mathrm{E}-01$

$1.00 \mathrm{E}-01$

$1.00 \mathrm{E}-01$

$1.00 \mathrm{E}-01$

$2.94 \mathrm{E}-09$

$1.67 \mathrm{E}-06$

$1.00 \mathrm{E}-01$

$\begin{array}{ll}1.71 \mathrm{E}-06 & 1.00 \mathrm{E}-0 \\ 6.96 \mathrm{E}-08 & 1.00 \mathrm{E}-0 \\ 2.94 \mathrm{E}-09 & 1.00 \mathrm{E}-0 \\ 1.67 \mathrm{E}-06 & 1.00 \mathrm{E}-0 \\ & \text { Total: }\end{array}$

Total:

Ref: ORNL/ER-365, Evaluation of Phase I and Phase II

Sampling and Analysis Data for the Gunite and Associated Tanks

at Oak Ridge National Laboratory, Oak Ridge, Tennessee,

March 1996.

Table 3.15. Treatability Study hazards identification summary

\begin{tabular}{|c|c|c|c|c|c|c|c|c|c|}
\hline $\begin{array}{c}\text { Facility } \\
\text { or } \\
\text { segment }\end{array}$ & $\begin{array}{c}\text { Fissionable } \\
\text { materials }\end{array}$ & $\begin{array}{c}\begin{array}{c}\text { Rad } \\
\text { sources }\end{array} \\
\end{array}$ & $\begin{array}{c}\text { Toxic/ } \\
\text { corrosive/ } \\
\text { reactive } \\
\text { materials } \\
\end{array}$ & $\begin{array}{c}\text { Flammable } \\
\text { materials }\end{array}$ & $\begin{array}{c}\text { Explosive/ } \\
\text { pyrophoric } \\
\text { materials } \\
\end{array}$ & $\begin{array}{r}\text { Electrical } \\
\text { energy } \\
\text { sources } \\
\end{array}$ & $\begin{array}{l}\text { Thermal } \\
\text { energy } \\
\text { sources }\end{array}$ & $\begin{array}{r}\text { Kinetic } \\
\text { energy } \\
\text { sources }\end{array}$ & $\begin{array}{c}\text { Potential } \\
\text { energy } \\
\text { sources }\end{array}$ \\
\hline $\begin{array}{l}\text { Support } \\
\text { system }\end{array}$ & - & $\bullet$ & - & & & - & - & - & - \\
\hline MLDUA & - & - & - & & & - & & - & - \\
\hline $\begin{array}{l}\text { Remote } \\
\text { operated } \\
\text { Vehicle } \\
\end{array}$ & $\bullet$ & $\bullet$ & - & & & $\bullet$ & & - & - \\
\hline $\begin{array}{l}\text { Decon } \\
\text { tent }\end{array}$ & $\bullet$ & • & - & & & - & & & \\
\hline
\end{tabular}




\subsubsection{Gunite and Associated Tanks: Treatability Study}

\subsubsection{Hazard identification}

The GAAT-TS operations were divided into systems for identification of hazards only. The facility classification for the GAAT-TS is based on the total inventory of hazardous and radioactive materials identified. The hazard identification tables for the GAAT-TS systems are included in Appendix C. Table 3.15 summarizes the hazards identified in each of the GAAT-TS systems.

Fissionable materials, radiation sources, toxic/corrosive/reactive materials, electrical energy, thermal energy, kinetic energy, and potential energy hazards were identified in the hazard identification tables for the Treatability Study. Fissionable materials are present in the liquid and sludge wastes in Tanks W-3 and W-4 and as contamination on equipment used to transfer sludges and liquids between the tanks. Table 3.16 lists the total amounts of fissionable materials in both tanks and determines the ${ }^{235} \mathrm{U}$ fissionable equivalent mass. Mass spectrometry indicates that the uranium present in the liquids and sludges is at natural concentrations. In discussions with the ORNL Criticality Safety Section, a review of ANSV/ANS-8.12 and ANSI/ANS-8.1 indicates that the amount of ${ }^{233} \mathrm{U}$ or ${ }^{239} \mathrm{Pu}$ which must be added to natural uranium to achieve criticality exceeds the Category 2 threshold amounts provided for those isotopes in DOE-STD-1027-92. ${ }^{1}$ Therefore the effects of the ${ }^{235} \mathrm{U}$ are such that the ${ }^{235} \mathrm{U}$, when in a natural or depleted ratio with ${ }^{238} \mathrm{U}$, does not need to be added to the fissionable mass equivalent when considering the criticality limits for hazard classification for DOE-STD-1027-92. ${ }^{1}$ The total amount of fissionable material (excluding the natural uranium) in the combined tanks is less than the fissionable material control limit ( $250 \mathrm{~g}^{235} \mathrm{U}$ fissionable equivalent mass). Therefore, the fissionable material hazard is screened out and is not evaluated further.

Radioactive materials are present in the liquid and sludge wastes present in Tanks W-3 and W-4 and as contamination on equipment used to transfer sludges and liquids between the tanks. Table.3.17 lists the total radioactive material inventory present in both tanks and compares the inventory with RQ values from 40 CFR $302.4 .^{5}$ The RQ values are exceeded indicating that the radioactive material hazard should be retained for further evaluation.

Toxic/corrosive/reactive materials are present in the liquid and sludges present in Tanks W-3 and W-4 and as contamination on equipment used to transfer sludges and liquids between the tanks. Comparison of the chemical constituents of the liquids and sludges present in the sluice water to regulatory limits contained in 40 CFR $302.4^{5}$ is difficult because discrete chemicals are not easily distinguished by sampling. It is important to consider the intent of the regulatory limits. The RQ values listed in 40 CFR $302.4^{5}$ are intended to identify facilities and processes with toxic material hazards that can have significant toxic consequences to on-site and off-site personnel during and following accidents. Most RQs are based on a pure chemical form that is susceptible to airborne releases when spilled, heated, or ignited. The chemicals present in the liquid and sludges are in aqueous solution or settled particulates and are not susceptible to cloud-type releases. However, the chemical make-up of the liquids and sludges associated with the Treatability study are assumed to exceed the RQ values in 40 CFR $302.4^{5}$ and are retained for further evaluation.

The electrical energy, thermal energy, and kinetic energy hazards identified in the hazards identification for the Treatability Study are all screened out by the screening criteria contained in ES/CSET-2/R2. ${ }^{4}$ 
Table 3.16. Evaluation of fissionable materials associated with the Treatability Study

\begin{tabular}{|c|c|c|c|c|c|c|c|c|c|c|c|c|}
\hline Tank & $\begin{array}{l}\text { Fissionable } \\
\text { nuclide }\end{array}$ & $\begin{array}{c}\text { Concentration } \\
(\mathrm{B} / \mathrm{g})\end{array}$ & $\begin{array}{l}\text { Volume } \\
\text { (gal) }\end{array}$ & $\begin{array}{l}\text { Density } \\
(\mathrm{g} / \mathrm{mL})\end{array}$ & $\begin{array}{c}\text { Total } \\
\text { activity (Ci) }\end{array}$ & $\begin{array}{l}\text { Half-life } \\
\text { (sec) }\end{array}$ & lambda & $\mathbf{M}$ & $\begin{array}{c}\text { Specific } \\
\text { activity } \\
(\mathrm{Ci} / \mathrm{g})\end{array}$ & $\begin{array}{c}\text { Total mass } \\
(\mathrm{g})\end{array}$ & $\begin{array}{c}\text { Mass factor for } U \text { - } \\
235 \text { fissionable } \\
\text { equivalent }\end{array}$ & $\begin{array}{c}\text { U-235 } \\
\text { fissionable } \\
\text { equivalent mass } \\
\text { (g) } \\
\end{array}$ \\
\hline \multirow[t]{8}{*}{ W-3 sludge } & U-233 & $1.10 \mathrm{E}+03$ & $6.28 \mathrm{E}+02$ & $1.07 \mathrm{E}+00$ & $7.56 \mathrm{E}-02$ & $5.02 \mathrm{E}+12$ & $1.38 \mathrm{E}-13$ & $2.33 E+02$ & $9.64 \mathrm{E}-03$ & $7.84 \mathrm{E}+00$ & $1.35 \mathrm{E}+00$ & $1.06 \mathrm{E}+01$ \\
\hline & U-235 & $5.80 \mathrm{E}+01$ & $6.28 \mathrm{E}+02$ & $1.07 \mathrm{E}+00$ & $3.99 \mathrm{E}-03$ & $2.22 \mathrm{E}+16$ & $3.12 \mathrm{E}-17$ & $2.35 \mathrm{E}+02$ & $2.16 \mathrm{E}-06$ & $1.85 E+03$ & $1.00 \mathrm{E}+00$ & $1.85 \mathrm{E}+03$ \\
\hline & $\mathrm{Pu}-238$ & $1.22 \mathrm{E}+03$ & $6.28 \mathrm{E}+02$ & $1.07 \mathrm{E}+00$ & 8.39E-02 & $2.77 \mathrm{E}+09$ & $2.50 \mathrm{E}-10$ & $2.38 \mathrm{E}+02$ & $1.71 \mathrm{E}+01$ & $4.90 \mathrm{E}-03$ & $2.30 \mathrm{E}-01$ & $1.13 \mathrm{E}-03$ \\
\hline & $\mathrm{Pu}-239$ & $3.86 \mathrm{E}+03$ & $6.28 \mathrm{E}+02$ & $1.07 \mathrm{E}+00$ & $2.65 \mathrm{E}-01$ & $7.61 \mathrm{E}+11$ & $9.11 \mathrm{E}-13$ & $2.39 \mathrm{E}+02$ & $6.20 \mathrm{E}-02$ & $4.28 \mathrm{E}+00$ & $1.56 \mathrm{E}+00$ & $6.68 \mathrm{E}+00$ \\
\hline & $\mathrm{Pu}-240$ & $4.58 \mathrm{E}+02$ & $6.28 \mathrm{E}+02$ & $1.07 \mathrm{E}+00$ & $3.15 \mathrm{E}-02$ & $2.06 \mathrm{E}+11$ & $3.36 \mathrm{E}-12$ & $2.40 \mathrm{E}+02$ & $2.28 \mathrm{E}-01$ & $1.38 \mathrm{E}-01$ & $4.70 \mathrm{E}-02$ & $6.50 \mathrm{E}-03$ \\
\hline & $\mathrm{Pu}-241$ & $6.04 \mathrm{E}+03$ & $6.28 \mathrm{E}+02$ & $1.07 \mathrm{E}+00$ & $4.15 \mathrm{E}-01$ & $4.54 \mathrm{E}+08$ & $1.53 \mathrm{E}-09$ & $2.41 \mathrm{E}+02$ & $1.03 \mathrm{E}+02$ & $4.03 \mathrm{E}-03$ & $3.50 \mathrm{E}+00$ & $1.41 \mathrm{E}-02$ \\
\hline & $\mathrm{Pu}-242$ & $2.25 \mathrm{E}-01$ & $6.28 \mathrm{E}+02$ & $1.07 \mathrm{E}+00$ & $1.55 \mathrm{E}-05$ & $1.19 \mathrm{E}+13$ & $5.84 \mathrm{E}-14$ & $2.42 \mathrm{E}+02$ & $3.93 \mathrm{E}-03$ & $3.94 \mathrm{E}-03$ & $1.80 \mathrm{E}-02$ & $7.09 \mathrm{E}-05$ \\
\hline & $\mathrm{Cm}-244$ & $1.08 \mathrm{E}+02$ & $6.28 \mathrm{E}+02$ & $1.07 \mathrm{E}+00$ & $7.42 \mathrm{E}-03$ & $5.72 \mathrm{E}+08$ & $1.21 \mathrm{E}-09$ & $2.44 E+02$ & $8.09 E+01$ & $9.18 \mathrm{E}-05$ & $2.30 \mathrm{E}-01$ & $2.11 \mathrm{E}-05$ \\
\hline \multirow[t]{2}{*}{ W-3 liquid } & U-233 & $9.32 \mathrm{E}+00$ & $1.57 \mathrm{E}+04$ & $1.00 \mathrm{E}+00$ & $1.50 \mathrm{E}-02$ & $5.02 \mathrm{E}+12$ & $1.38 \mathrm{E}-13$ & $2.33 \mathrm{E}+02$ & $9.64 \mathrm{E}-03$ & $1.55 \mathrm{E}+00$ & $1.35 \mathrm{E}+00$ & $2.09 \mathrm{E}+00$ \\
\hline & U-235 & $1.29 \mathrm{E}-01$ & $1.57 \mathrm{E}+04$ & $1.00 \mathrm{E}+00$ & $2.07 E-04$ & $2.22 \mathrm{E}+16$ & 3.12E-17 & $2.35 \mathrm{E}+02$ & $2.16 \mathrm{E}-06$ & $9.59 \mathrm{E}+01$ & $1.00 \mathrm{E}+00$ & $9.59 \mathrm{E}+01$ \\
\hline \multirow[t]{9}{*}{ W-4 sludge } & U-233 & $5.33 E+02$ & $1.31 \mathrm{E}+03$ & $1.28 \mathrm{E}+00$ & $9.16 \mathrm{E}-02$ & $5.02 \mathrm{E}+12$ & $1.38 \mathrm{E}-13$ & $2.33 E+02$ & $9.64 \mathrm{E}-03$ & $9.50 \mathrm{E}+00$ & $1.35 \mathrm{E}+00$ & $1.28 \mathrm{E}+01$ \\
\hline & $\mathrm{U}-235$ & $9.97 \mathrm{E}+01$ & $1.31 \mathrm{E}+03$ & $1.28 \mathrm{E}+00$ & $1.71 \mathrm{E}-02$ & $2.22 \mathrm{E}+16$ & 3.12E-17 & $2.35 \mathrm{E}+02$ & $2.16 \mathrm{E}-06$ & $7.94 \mathrm{E}+03$ & $1.00 \mathrm{E}+00$ & $7.94 \mathrm{E}+03$ \\
\hline & $\mathrm{Pu}-238$ & $4.67 \mathrm{E}+02$ & $1.31 \mathrm{E}+03$ & $1.28 \mathrm{E}+00$ & $8.03 E-02$ & $2.77 \mathrm{E}+09$ & $2.50 \mathrm{E}-10$ & $2.38 \mathrm{E}+02$ & $1.71 \mathrm{E}+01$ & $4.69 \mathrm{E}-03$ & $2.30 \mathrm{E}-01$ & $1.08 \mathrm{E}-03$ \\
\hline & Pu-239 & $7.96 \mathrm{E}+03$ & $1.31 \mathrm{E}+03$ & $1.28 \mathrm{E}+00$ & $1.37 \mathrm{E}+00$ & $7.61 \mathrm{E}+11$ & $9.11 E-13$ & $2.39 \mathrm{E}+02$ & $6.20 \mathrm{E}-02$ & $2.21 \mathrm{E}+01$ & $1.56 \mathrm{E}+00$ & $3.44 \mathrm{E}+01$ \\
\hline & $\mathrm{Pu}-240$ & $9.50 \mathrm{E}+02$ & $1.31 \mathrm{E}+03$ & $1.28 \mathrm{E}+00$ & $1.63 \mathrm{E}-01$ & $2.06 \mathrm{E}+11$ & 3.36E-12 & $2.40 \mathrm{E}+02$ & $2.28 \mathrm{E}-01$ & 7.17E-01 & $4.70 \mathrm{E}-02$ & 3.37E-02 \\
\hline & $\mathrm{Pu}-241$ & $6.85 \mathrm{E}+03$ & $1.31 E+03$ & $1.28 \mathrm{E}+00$ & $1.18 \mathrm{E}+00$ & $4.54 \mathrm{E}+08$ & $1.53 \mathrm{E}-09$ & $2.41 E+02$ & $1.03 E+02$ & $1.14 \mathrm{E}-02$ & $3.50 \mathrm{E}+00$ & $4.00 \mathrm{E}-02$ \\
\hline & $\mathrm{Pu}-242$ & $2.10 \mathrm{E}-01$ & $1.31 \mathrm{E}+03$ & $1.28 \mathrm{E}+00$ & 3.61E-05 & $1.19 \mathrm{E}+13$ & $5.84 \mathrm{E}-14$ & $2.42 \mathrm{E}+02$ & $3.93 \mathrm{E}-03$ & $9.20 \mathrm{E}-03$ & $1.80 \mathrm{E}-02$ & $1.66 \mathrm{E}-04$ \\
\hline & $A m-241$ & $2.05 E+03$ & $1.31 \mathrm{E}+03$ & $1.28 \mathrm{E}+00$ & $3.52 \mathrm{E}-01$ & $1.36 \mathrm{E}+10$ & 5.10E-11 & $2.41 \mathrm{E}+02$ & $3.44 \mathrm{E}+00$ & $1.02 \mathrm{E}-01$ & $4.40 \mathrm{E}-02$ & $4.51 \mathrm{E}-03$ \\
\hline & $\mathrm{Cm}-244$ & $2.02 \mathrm{E}+02$ & $1.31 \mathrm{E}+03$ & $1.28 \mathrm{E}+00$ & $3.47 \mathrm{E}-02$ & $5.72 \mathrm{E}+08$ & $1.21 \mathrm{E}-09$ & $2.44 \mathrm{E}+02$ & $8.09 \mathrm{E}+01$ & $4.30 \mathrm{E}-04$ & $2.30 \mathrm{E}-01$ & $9.88 \mathrm{E}-05$ \\
\hline \multirow[t]{2}{*}{ W-4 liquid } & U-233 & $1.54 \mathrm{E}+00$ & $2.98 \mathrm{E}+04$ & $1.01 \mathrm{E}+00$ & $4.73 \mathrm{E}-03$ & $5.02 \mathrm{E}+12$ & $1.38 \mathrm{E}-13$ & $2.33 \mathrm{E}+02$ & $9.64 \mathrm{E}-03$ & $4.91 \mathrm{E}-01$ & $1.35 \mathrm{E}+00$ & $6.63 \mathrm{E}-01$ \\
\hline & U.235 & $5.97 \mathrm{E}-01$ & $2.98 \mathrm{E}+04$ & $1.01 \mathrm{E}+00$ & $1.84 \mathrm{E}-03$ & $2.22 \mathrm{E}+16$ & 3.12E-17 & $2.35 \mathrm{E}+02$ & $2.16 \mathrm{E}-06$ & $8.50 \mathrm{E}+02$ & $1.00 \mathrm{E}+00$ & $8.50 \mathrm{E}+02$ \\
\hline
\end{tabular}

Note: Mass spectrometry indicates that the uranium present in both Tanks W-3 and W-4 is at natural concentrations. Natural uranium, by nature, does not present an inadvertent criticality risk and is not considered fissionable. The total U-235 fissionable equivalent mass (not including the natural uranium) is determined to be: 
Potential energy is present in the form of high pressure sluice water supply (up to 7,000 psig). The high pressure sluice water supply exceeds the criteria from ES/CSET-2/R2. ${ }^{4}$ The supply water is filtered process water, contains no hazardous or radioactive materials, and has a relatively low flow rate (10 gpm from each of two pumps). The high pressure water is used to break up sludge deposits in the CSEE and as the motive force in the jet pump which transfers the sludges out of the tank. The pumps are commercially procured and the high pressure lines are up to 1 inch hoses and pipes. The range of potential injuries from failures of the high pressure system are only in the immediate area of the pumps and piping. The low volume and high pressure process water supply are an occupational energy hazard. Prior to operation in the TS, the high pressure system will be reviewed and approved by the ORNL High Pressure Equipment Review Committee whose specific purpose is to provide independent safety oversight for operation of equipment with an operating pressure over $3,000 \mathrm{psig}$. Therefore, the potential energy hazard is screened out as discussed in ES/CSET-2/R2 ${ }^{4}$ Section 4.2.5.5 and is not considered for further evaluation.

\subsubsection{Preliminary hazard classification}

Table 3.17 lists the total quantities of radioactive materials in both Tanks W-3 and W-4 and compares the total inventory to the RQ values from 40 CFR $302.4{ }^{5}$ The $R Q$ values are exceeded by the inventory of material in the tanks. The total inventory of radioactive materials is compared to the Category 3 TQs in Table 3.17. If the entire quantity of supernate and sludges from both tanks were releasable, the summed ratio exceeds 1.0. Therefore, the preliminary nuclear facility hazard classification is "Category 3."

As stated in Subsect. 3.3.2.1, it is assumed that the RQ values from 40 CFR $302.4^{5}$ are exceeded. The non-nuclear hazard classification is conducted in accordance with the methodology in ES/CSET-2/R2 ${ }^{4}$ Calculation of airborne concentrations of hazardous materials is conducted in calc-note DAC-PX446G01-SSE-0026. The consequence calculation assumed a release fraction $1 E-04$, which is for simple spills at pressures up to $200 \mathrm{psig}^{10}, 30$ meters to the receptor and a bounding sludge/supernate release rate of $100 \mathrm{gpm}$. It was determined that the consequences of release of hazardous chemicals from sludge removal operations are negligible to both on-site and off-site personnel. Therefore, the nonnuclear hazard classification is "Industrial."

\subsection{HAZARD ANALYSIS RESULTS}

\subsubsection{North Tank Farm}

\subsubsection{Preliminary hazards analysis}

The PHA for the NTF operations is included as Appendix D.

\subsubsection{Preliminary hazards analysis summary}

The NTF tanks are inactive. Therefore, the PHA focuses on accidents associated with failures of the confinement boundary (the tanks) initiated by random failure, natural phenomena, or external energy sources. Other accidents considered were tank overfill and HEPA filter failures (Tank W-1A only).

The release scenarios identified for the tanks in the NTF included tank leaks (due to random component failure, heavy loads, construction or vehicle accidents, and earthquakes), tank overfill (due to problems in the process water supply system, local flooding, or inadvertent transfer to inactive tank), 


\section{3-22}

Table 3.17. Treatability Study inventory analysis

Tanks W-3 and W-4 Combined Inventories

\begin{tabular}{|c|c|c|c|c|c|}
\hline Nuclide & Total Activity (Ci) & $\begin{array}{c}40 \text { CFR } 302.2 \mathrm{RQ} \\
\text { (Ci) }\end{array}$ & $\begin{array}{c}\text { Fraction of } \\
\text { RQ }\end{array}$ & $\begin{array}{l}\text { DOE-STD-1027-92 } \\
\text { Category } 3 \text { TQ (Ci) }\end{array}$ & Fraction of TQ \\
\hline $\mathrm{H}-3$ & $1.09 \mathrm{E}-02$ & $1.00 \mathrm{E}+02$ & $1.09 \mathrm{E}-04$ & $1.00 \mathrm{E}+03$ & $1.09 \mathrm{E}-05$ \\
\hline $\mathrm{Co}_{-60}$ & $3.97 \mathrm{E}-01$ & $1.00 \mathrm{E}+01$ & $3.97 \mathrm{E}-02$ & $2.80 \mathrm{E}+02$ & $1.42 \mathrm{E}-03$ \\
\hline Cs-137/Ba-137m & $9.98 \mathrm{E}+01$ & $1.00 \mathrm{E}+00$ & $9.98 \mathrm{E}+01$ & $6.00 \mathrm{E}+01$ & $1.66 \mathrm{E}+00$ \\
\hline Eu-154 & $5.22 \mathrm{E}-03$ & $1.00 \mathrm{E}+01$ & $5.22 \mathrm{E}-04$ & $2.00 \mathrm{E}+02$ & $2.61 \mathrm{E}-05$ \\
\hline Sr-90 & $7.73 \mathrm{E}+01$ & $1.00 \mathrm{E}-01$ & $7.73 E+02$ & $1.60 E+01$ & $4.83 E+00$ \\
\hline Am-241 & $1.41 \mathrm{E}-01$ & $1.00 \mathrm{E}-02$ & $1.41 E+01$ & $5.20 \mathrm{E}-01$ & $2.71 \mathrm{E}-01$ \\
\hline $\mathrm{Cm}-244^{* *}$ & $4.71 E-02$ & $1.00 \mathrm{E}-02$ & $4.71 \mathrm{E}+00$ & $1.00 \mathrm{E}+00$ & $4.71 \mathrm{E}-02$ \\
\hline$C f-252$ & $1.18 E-03$ & $1.00 \mathrm{E}-01$ & $1.18 \mathrm{E}-02$ & $3.20 \mathrm{E}+00$ & $3.68 \mathrm{E}-04$ \\
\hline U-233 & $1.87 \mathrm{E}-01$ & $1.00 \mathrm{E}-01$ & $1.87 \mathrm{E}+00$ & 4. $20 \mathrm{E}+00$ & $4.45 \mathrm{E}-02$ \\
\hline U-234 & $5.88 \mathrm{E}-01$ & $1.00 \mathrm{E}-01$ & $5.88 E+00$ & $4.20 E+00$ & $1.40 E-01$ \\
\hline U-235 & $2.32 \mathrm{E}-02$ & $1.00 \mathrm{E}-01$ & $2.32 \mathrm{E}-01$ & $4.20 \mathrm{E}+00$ & $5.52 \mathrm{E}-03$ \\
\hline U-236* & $1.42 \mathrm{E}-03$ & $1.00 \mathrm{E}-01$ & $1.42 \mathrm{E}-02$ & $4.20 \mathrm{E}+00$ & $3.37 \mathrm{E}-04$ \\
\hline U-238 & $5.66 \mathrm{E}-01$ & $1.00 \mathrm{E}-01$ & $5.66 \mathrm{E}+00$ & $4.20 \mathrm{E}+00$ & $1.35 \mathrm{E}-01$ \\
\hline $\mathrm{Pu}-238$ & $1.64 \mathrm{E}-01$ & $1.00 \mathrm{E}-02$ & $1.64 E+01$ & $6.20 \mathrm{E}-01$ & 2.6SE-01 \\
\hline Pu-239 & $1.63 \mathrm{E}+00$ & $1.00 \mathrm{E}-02$ & $1.63 E+02$ & $5.20 \mathrm{E}-01$ & $3.14 \mathrm{E}+00$ \\
\hline Pu-240** & $1.95 E-01$ & $1.00 \mathrm{E}-02$ & $1.95 E+01$ & $5.20 \mathrm{E}-01$ & $3.75 E-01$ \\
\hline Pu-241 & $1.59 \mathrm{E}+00$ & $1.00 \mathrm{E}+00$ & $1.59 E+00$ & $3.20 \mathrm{E}+01$ & $4.98 E-02$ \\
\hline Pu-242** & 3.07E-01 & $1.00 \mathrm{E}-02$ & $3.07 \mathrm{E}+01$ & $6.20 \mathrm{E}-01$ & $4.95 \mathrm{E}-01$ \\
\hline $\mathrm{Pu}-244^{* *}$ & $4.32 \mathrm{E}-10$ & $1.00 \mathrm{E}-02$ & $4.32 \mathrm{E}-08$ & $6.20 \mathrm{E}-01$ & $6.96 \mathrm{E}-10$ \\
\hline
\end{tabular}

* TQ determined based on ratio of dose conversion factors for U-236 and U-235 and Cat. 3 TQ for U-235.

** TQ taken from information Ray Schwartz provided to Milt Kreger dated 3-26-93. (Engineering Transmittal XSSE-653 dated 10-29-94, PRN X1993-0066.) 
pipe leaks (due to random component failure, low temperatures, and construction or vehicle accidents), and HEPA filter failures (due to random component failure, improper installation, maintenance error, high wind, construction or vehicle accidents, and fires). Many of the release scenarios involve liquid release to the ground at or below the ground surface level. None of the accident scenarios identified result in large airborne releases and none are expected to result in significant adverse health effects to on-site or off-site personnel.

\subsubsection{Final facility hazard classification}

Further analysis was performed for the radioactive material inventories in Tanks W-3 and W-4 to determine the final facility hazard categorization. Calc-note DAC-PX446G01-SSE- $003^{9}$ evaluates the consequences resulting from the bounding release of the radioactive materials. The analysis conservatively assumed a release of the combined W-3 and W-4 materials. Based on the results of the PHA, the inhalation calculation assumed a release fraction 1E-04, which is for simple spills at pressures up to $200 \mathrm{psig}^{10}$, and 30 meters to the receptor. The material was assumed to be released over the period of 1 hour. Since the receptor was exposed for the duration of the release, the release rate does not affect the final results. The inhalation calculation assumed a wind speed of $4.5 \mathrm{~m} / \mathrm{sec}$ with a "D" stability. The direct dose calculation assumed a point-source exposure at 30 meters for 24 hours. The total inhalation exposure is $0.7 \mathrm{rem}$ inhalation and $0.7 \mathrm{rem}$ direct dose for a total dose of $1.4 \mathrm{rem}$. This is well below the 10 rem threshold discussed in Section 2.3.2, "Final Facility Hazard Classification," for a low hazard facility. The final facility hazard classifications for NTF tanks are as follows:

\begin{tabular}{llr} 
Tank & Nuclear classification & Non-nuclear class \\
\cline { 2 - 3 } W-1 & Industrial & \\
W-1A & Industrial & \\
W-2 & Industrial & Industrial \\
W-3 & Radiological & Industrial \\
W-4 & Radiological & Industrial \\
W-13 & Radiological & Industrial \\
W-14 & Radiological & Industrial \\
W-15 & Radiological & Industrial \\
& & Industrial
\end{tabular}

\subsubsection{Tank W-11}

\subsubsection{Preliminary hazards analysis}

No unusual hazardous material or energy sources were retained from the hazards identification effort. Therefore, no PHA was performed for Tank W-11.

\subsubsection{Final facility hazard classification}

The final nuclear facility classification for Tank W-11 is Industrial. The final non-nuclear facility classification for Tank W-11 is Industrial.

\subsubsection{Gunite and Associated Tanks: Treatability Study}

\subsubsection{Preliminary hazards analysis}

The PHA for the GAAT-TS operations is included in Appendix F. 


\subsubsection{Preliminary hazards analysis summary}

The PHA for the GAAT-TS focused mainly on accidents that may result in aboveground releases of the radioactive and hazardous materials present in the liquids and sludges being transferred between Tanks W-3 and W-4.

The release scenarios identified for the GAAT-TS included tank leaks (due to random component failure, dropped equipment, earthquake, and construction or vehicle accidents), tank overfill (due to process water flow into tanks), pipe leaks (due to random component failure, earthquakes, high winds, and low temperatures), HEPA filter failure (due to fire in tanks, random component failure, improper installation, maintenance error, adjacent facility fire), and ventilation system failures. Many of the accident scenarios involve liquid release to the ground at or below the ground surface level. Several of the accidents involve release of aerosols generated inside the tank during sluicing activities through the ventilation exhaust or through tank penetrations (in the event of tank exhaust failure). Releases from intertank piping may result in the generation of airborne "sprays" from the spilling liquid. Theoretically, a failure in the piping between the tanks could result in a release that could continue until the entire sludge and liquid inventory in the supply tank is released. If the failure occurs after the volume of the two tanks are combined, the entire inventory of tanks W-3 and W-4 could be released and create an airborne hazard. This accident is chosen as the bounding accident identified in the PHA.

\subsubsection{Final facility hazard classification}

Calc-note DAC-PX446G01-SSE- $003^{9}$ evaluates the consequences resulting from the bounding release of the radioactive materials. The analysis conservatively assumed a release of the combined W-3 and W-4 materials. Based on the results of the PHA, the inhalation calculation assumed a release fraction IE-04, which is for simple spills at pressures up to $200 \mathrm{psig}^{10}$, and 30 meters to the receptor. The material was assumed to be released over the period of 1 hour. Since the receptor was exposed for the duration of the release, the release rate does not affect the final results. The inhalation calculation assumed a wind speed of $4.5 \mathrm{~m} / \mathrm{sec}$ with a " $D$ " stability. The direct dose calculation assumed a pointsource exposure at 30 meters for 24 hours. The total inhalation exposure is $0.7 \mathrm{rem}$ inhalation and $0.7 \mathrm{rem}$ direct dose for a total dose of $1.4 \mathrm{rem}$. This is well below the $10 \mathrm{rem}$ threshold discussed in Section 2.3.2, "Final Facility Hazard Classification," for a low hazard facility.

The final facility hazard categorizations for the GAAT-TS are:

$$
\begin{array}{ll}
\text { Nuclear classification: } & \text { Radiological } \\
\text { Non-nuclear classification: } & \text { Industrial }
\end{array}
$$

\subsection{REFERENCES}

1. DOE-STD-1027-92, Hazard Categorization and Accident Analysis Techniques for Compliance with DOE Order 5480.23, Nuclear Safety Analysis Reports, U.S. Department of Energy, Washington, D.C., December 1992.

2. DOE Order 5480.23, Nuclear Safety Analysis Reports, U.S. Department of Energy, Washington, D.C., April 30, 1992.

3. DOE-STD-3009-94, Preparation Guide for U.S. Department of Energy Non-reactor Nuclear Facility Safety Analysis Reports, U.S. Department of Energy, Washington, D.C., July 1994. 
4. ES/CSET-2/R2, Safety Analysis Report Update Program Hazard Identification and Facility Classification Application Guide, Lockheed Martin Energy Systems, Inc., Oak Ridge, Tennessee, December 1995.

5. Title 40 Code of Federal Regulations, Part 302, Designation, Reportable Quantities, and Notification, Section 4, "Designation of hazardous substances."

6. Non-Nuclear Facility Classification for Tanks $W-1, W-1 A, W-2, W-3, W-4, W-11, W-13, W-14$, and $W-15$, and the Gunite and Associated Tanks Treatability Study, DAC-PX446G01-SSE-002.

7. ORNL/ER-365, Evaluation of Phase I and Phase II Sampling and Analysis Data for the Gunite and Associated Tanks at the Oak Ridge National Laboratory, Oak Ridge, Tennessee, March 1996.

8. ORNL/ER-13, Sampling and Analysis of Inactive Waste Storage Tank Contents at ORNL, Oak Ridge, Tennessee, September 1990.

9. Nuclear Facility Classification for Tanks $W-1, W-1 A, W-2, W-3, W-4, W-11, W-13, W-14$, and $W-15$, and the Gunite and Associated Tanks Treatability Study, DAC-PX446G01-SSE-003.

10. DOE-HDBK-3010-94, Airborne Release Fraction/Rates and Respirable Fractions for Nonreactor Nuclear Facilities, U.S. Department of Energy, Washington, D.C., December 1994. 


\section{PREVENTION OF INADVERTENT CRITICALITY}

\subsection{FISSIONABLE MATERIAL IN TANKS}

It was shown in Chap. 3, Hazard Analysis, that the amount of fissionable materials, excluding the ${ }^{235} \mathrm{U}$ in the depleted or natural uranium, detected in the NTF tanks and Tank W-11 during sampling operations is well below the fissionable material control limit of $250 \mathrm{~g}{ }^{235} \mathrm{U}$ fissionable equivalent mass. These quantities are below the quantities which require the application of the ORNL Nuclear Criticality Safety Program controls as discussed in ORNL Nuclear Criticality Safety Procedure NCS-1.0, "Nuclear Criticality Safety Program."'

\subsection{REFERENCES}

1. NCS-1.0, Nuclear Criticality Safety Program, Oak Ridge National Laboratory, Oak Ridge, Tennessee, February 18, 1994. 


\section{RADIATION PROTECTION}

\subsection{RADIATION PROTECTION PROGRAM}

The radiation protection program is designed to protect workers from the harmful effects of radiation. The GAAT Project and the NTF surveillance and maintenance activities will be performed under the control of the Incentive Task Order (ITO) process. ITOs provide the negotiated basis for all requirements for the subject activities including the requirements for Health and Safety Programs. The ITO proposal will include requirements that have a radiation protection program that accomplishes the following objectives.

- Maintaining radiation exposure at levels that are as low as reasonably achievable (ALARA),

- Limiting internal and external radiation exposure of occupational workers,

- Monitoring and recording occupational exposure,

- Labeling radioactive materials,

- Posting and establishing entry control programs for areas where elevated radiation fields and contamination may be present, and

- Providing periodic radiation safety training.

\subsection{RADIOLOGICAL MONITORING}

Radiological monitoring is performed periodically at the NTF, at Tank W-11, and as a part of the Treatability Study to ensure that personnel doses are maintained ALARA and to minimize the spread of contamination by early detection. In the NTF, the tank dry wells are monitored and sampled monthly, the off-gas systems are tested quarterly, and radiological surveys are taken semi-annually. Health physics personnel will monitor Treatability Study operations and perform radiological surveys as needed or requested.

\subsection{RADIOLOGICAL PROTECTION INSTRUMENTATION}

There is no permanently installed radiation protection instrumentation provided for the NTF tanks or Tank W-11. When personnel are required to enter the area for surveillance and maintenance activities, information on radiation exposure is collected using personal radiation detectors. Appropriate radiation protection instrumentation for personnel frisking upon exiting is specified and provided by Health Physics as needed.

Radiation protection instrumentation such as the half-body counter Personnel Contamination Monitor (PCM)-1B, will be located near the controlled area egress point for monitoring. The PCM-1B will be used where frisking is required to exist the potentially contaminated platform areal. Hand frisking will be used as necessary as a backup to the PCM-1B. Health Physics will provide additional radiological protection instrumentation during Treatability Study operations to ensure that contamination is detected and controlled and that personnel exposures are maintained ALARA. 


\subsection{OCCUPATIONAL RADIATION EXPOSURES FOR TREATABILITY STUDY}

Reference 1 calculates an estimate of exposure rates resulting from transfer of LLLW through piping between the tanks. Table 5.1 lists the exposure rates resulting from estimated maximum source terms from Tanks W-3 and W-4 at distances from the pipe ranging from 2 in. to 92 in. These distances represent dose rates to personnel who may be present on the operating platform during transfer operations. It is not expected that personnel will be routinely present on the platform during transfer operations. Most operations can be performed remotely. When operations require access to the platform during transfer, Health Physics will closely monitor the dose received by the person(s) performing the work.

\subsection{REFERENCES}

1. "Estimate of Exposure Rates for Tanks W-3/W-4 Transfer," Central Engineering Records System, Project Records Number X1994-0055, Transmittal Number GAATTS 614, dated March 29, 1996. 


$$
5-3
$$

Table 5.1. Estimate of exposure rates for Tanks W-3/W-4 transfers

\begin{tabular}{ccc}
\hline \hline $\begin{array}{c}\text { Distance from transfer } \\
\text { line } \\
\text { (in.) }\end{array}$ & $\begin{array}{c}\text { Exposure rate using maximum } \\
\text { Tank W-3 source term } \\
(\mathrm{mR} / \mathrm{hr})\end{array}$ & $\begin{array}{c}\text { Exposure rate using maximum } \\
\text { Tank } \begin{array}{c}\text { W-4 source term } \\
\text { (mR/hr) }\end{array}\end{array}$ \\
\hline 2 & $2.15 \mathrm{E}+1$ & $1.48 \mathrm{E}+2$ \\
8 & $5.13 \mathrm{E}+0$ & $3.54 \mathrm{E}+1$ \\
14 & $2.93 \mathrm{E}+0$ & $2.02 \mathrm{E}+1$ \\
20 & $2.04 \mathrm{E}+0$ & $1.41 \mathrm{E}+1$ \\
26 & $1.55 \mathrm{E}+0$ & $1.08 \mathrm{E}+1$ \\
32 & $1.25 \mathrm{E}+0$ & $8.71 \mathrm{E}+0$ \\
38 & $1.06 \mathrm{E}+0$ & $7.27 \mathrm{E}+0$ \\
44 & $9.03 \mathrm{E}-1$ & $6.22 \mathrm{E}+0$ \\
50 & $7.85 \mathrm{E}-1$ & $5.41 \mathrm{E}+0$ \\
56 & $6.93 \mathrm{E}-1$ & $4.77 \mathrm{E}+0$ \\
62 & $6.17 \mathrm{E}-1$ & $4.25 \mathrm{E}+0$ \\
68 & $5.55 \mathrm{E}-1$ & $3.82 \mathrm{E}+6$ \\
74 & $5.03 \mathrm{E}-1$ & $3.46 \mathrm{E}+0$ \\
80 & $4.58 \mathrm{E}-1$ & $3.15 \mathrm{E}+0$ \\
86 & $4.19 \mathrm{E}-1$ & $2.89 \mathrm{E}+0$ \\
92 & $3.86 \mathrm{E}-1$ & $2.66 \mathrm{E}+0$ \\
\hline
\end{tabular}





\section{INITIAL TESTING AND MAINTENANCE}

\subsection{TREATABILITY STUDY INITIAL TESTING}

The operational testing program for the Treatability Study is detailed in ORNL/ER-361. ${ }^{1}$ The operational testing program identifies operational testing to be performed to demonstrate the technical feasibility of methods proposed for the removal of radiochemical sludge heels from Tanks W-3 and W-4, reduce the uncertainty in meeting Comprehensive Environmental Response, Compensation, and Liability Act (CERCLA) requirements, and minimize the overall costs to accomplish the first two objectives.

The initial testing program includes evaluation of design alternatives, acceptance tests of purchased components with performance specifications, and functional tests on equipment. Functional testing activities will be initially conducted in a nonradioactive environment at ORNL. This will permit the design and initial performance testing and training activities to be completed while minimizing the risk, employee exposure, and costs associated with the testing effort.

\subsection{MAINTENANCE PROGRAM}

The maintenance program ensures that DOE property is maintained in a manner which promotes operational safety, worker health, environmental protection and compliance, property preservation, and cost effectiveness while meeting the programmatic mission. The GAAT Project and the NTF surveillance and maintenance activities will be performed under the control of the ITO process. ITOs provide the negotiated basis for all requirements for the subject activities including the requirements for the Health and Safety Programs. The ITO proposal will include requirements that have a maintenance program that accomplishes the following objectives:

- Structures, systems, and components that are important to safe operation are subject to a maintenance program in order to meet or exceed their design requirements throughout their life.

- Periodic inspection of structures, systems, components, and equipment is performed to determine deterioration or technical obsolescence which threatens performance and/or safety.

- Primary responsibility, authority, and accountability for the direction and management of the maintenance programs for all property reside with the line management assigned direct programmatic responsibility.

\subsection{REFERENCES}

1. ORNL/ER-361, Treatability Study Operational Testing Program and Implementation Plan for the Gunite and Associated Tanks at Oak Ridge National Laboratory, Oak Ridge, Tennessee, Lockheed Martin Energy Systems, Inc., Oak Ridge, Tennessee, March 1996. 



\section{OPERATIONAL SAFETY}

\subsection{CONDUCT OF OPERATIONS}

The conduct of operations program ensures that operations at DOE facilities are managed, organized, and conducted in a manner to assure an acceptable level of safety. The GAAT Project and the NTF surveillance and maintenance activities will be performed under the control of the ITO process. ITOs provide the negotiated basis for all requirements for the subject activities including the requirements for the Health and Safety Programs. The ITO proposal will include requirements that have an operational safety program that accomplishes the following objectives:

- Facility operators have procedures in place to control the conduct of their operations,

- Line organizations review existing and planned programs important to safe and reliable facility operations, and

- Line organizations assess the effectiveness of corporate directives, plans, or procedures at facilities under their cognizance.

Site programs are maintained that provide requirements for industrial safety and industrial hygiene at ORNL. These programs include detailed procedures that apply to all ORNL operations and activities. The industrial hygiene program includes provisions for:

- Hazard communication,

- Health hazard management,

- Hearing conservation,

- Respiratory protection,

- Embryo/fetus protection,

- Employee education and training,

- Hazardous waste operations and emergency response,

- Investigation of health hazard incidents and concerns, and

- Hazardous materials inventory.

The industrial safety program includes provisions for:

- Safety and health program,

- Unusual occurrence reporting,

- Recordable injury and illness investigation,

- Safety and health suggestions,

- Safety orientation and training,

- Eye, face, hand, and foot protection,

- Compressed gas cylinders,

- Electrical safety,

- Use of safety work permits,

- Operating rules and qualification test for operators of forklift trucks,

- Lockout/tagout of hazardous energy sources,

- Use of "Do Not Operate" tags and other safety-related tags, and

- Safety showers and eye/face wash facilities. 


\subsubsection{North Tank Farm and Tank W-11}

The only operations routinely conducted in the NTF and at Tank W-11 are surveillance and maintenance activities. Requirements for these activities are outlined in the ITO. The activities performed include site inspections, tank monitoring, dry well monitoring, radiological surveys, and various maintenance activities as required. The NTF facility manager is responsible for ensuring that procedures are in place for all activities and that the activities adhere to corporate, site, and division policies and procedures governing industrial hygiene and safety.

\subsubsection{Treatability Study}

The conduct of operations for the Treatability Study testing program is outlined in ORNL/ER-361. ${ }^{3}$ The activities performed as part of the Treatability Study include initial testing of equipment and systems and evaluation of sludge removal equipment by transferring sludges between Tanks W-3 and W-4 at the NTF. Guidelines for the preparation of these procedures are included in ORNL/ER-361. ${ }^{1}$

\subsection{FIRE PROTECTION}

The GAAT Project and the NTF surveillance and maintenance activities will be performed under the control of the ITO process. ITOs provide the negotiated basis for all requirements for the subject activities including the requirements for the Health and Safety Programs. The ITO proposal will include requirements that have a fire protection program that accomplishes the following objectives:

- Maintaining a firefighting crew on a 24-hr basis,

- Investigating and reporting on all fires,

- Providing, installing, and maintaining firefighting equipment,

- Inspection of facilities for potential fire hazards,

- Conducting fire safety education and training programs each year,

- Training non-Fire Department employees in firefighting procedures as requested by their supervisor and/or Laboratory Shift Superintendent,

- Providing Fire Protection Engineering Services, and

- Conducting fire protection surveys.

Periodic inspections for fire hazards and fire extinguishers are required. Fire exit or evacuation drills are conducted periodically as determined necessary by the Laboratory Director, Laboratory Shift Superintendent, or the facility supervisor. 


\subsection{REFERENCES}

1. ORNL/ER-361, Treatability Study Operational Testing Program and Implementation Plan for the Gunite and Associated Tanks at Oak Ridge National Laboratory, Oak Ridge, Tennessee, Lockheed Martin Energy Systems, Inc., Oak Ridge, Tennessee, March 1996. 



\section{PROCEDURES AND TRAINING}

\subsection{PROCEDURE PROGRAM}

The procedures program provides for the development, implementation, and maintenance of procedures governing operation of ORNL facilities. The GAAT Project and the NTF surveillance and maintenance activities will be performed under the control of the ITO process. ITOs provide the negotiated basis for all requirements for the subject activities including the requirements for the Health and Safety Programs. The ITO proposal will include requirements that have a procedure program that accomplishes the following objectives:

- Procedures identify the responsible implementing organizations and/or individuals and the actions required,

- Procedures are kept current by formal issuance of revisions as conditions change,

- New procedures and revisions to procedures are subject to a documented review and approved by the facility manager or his designee, and

- Current revisions of procedures approved for use are retrievable and placed on controlled distribution to identified users.

The procedures program is implemented by division plans, procedures and guidance, as well as site procedures and standards.

\subsection{TRAINING PROGRAM}

The training program provides for general safety training for site employees as well as initial and periodic safety training for operators. The GAAT Project and the NTF surveillance and maintenance activities will be performed under the control of the ITO process. ITOs provide the negotiated basis for all requirements for the subject activities including the requirements for the Health and Safety Programs. The ITO proposal will include requirements that have a training program that accomplishes the following objectives:

- On-site personnel receive general employee training to acquaint the individual with site-wide procedures, alarms, and responsibilities,

- Personnel receive periodic training to maintain a level of proficiency consistent with assigned tasks, and

- Personnel are qualified to carry out their assigned responsibilities.

Specific requirements for training in support of the Treatability Study are detailed in the GAAT-TS Training Plan.' 
$8-2$

8.3 REFERENCES

1. Gunite and Associated Tanks Treatability Study Training Plan, Revision 0, dated 7-23-96 (Engineering Transmittal GAATTS 801 dated 7-26-96, PRN X1994-0055). 


\section{EMERGENCY PREPAREDNESS PROGRAM}

The emergency preparedness program is provided to ensure the safety and health of workers and members of the general public, as well as protect the environment. The GAAT Project and the NTF surveillance and maintenance activities will be performed under the control of the ITO process. ITOs provide the negotiated basis for all requirements for the subject activities including the requirements for the Health and Safety Programs. The ITO proposal will include requirements that have an emergency preparedness program that accomplishes the following objectives:

- Develop and maintain emergency planning, preparedness, and response capabilities, as well as effective public and interagency communications, in order to minimize the consequence to workers, national security, the public, and the environment from incidents involving DOE operations,

- Respond to emergencies in an effective and timely manner to mitigate the consequences and bring the emergency situation under control, and

- Provide support, within resource constraints, to other local, state, and Federal agencies and international organizations, as requested, and in accordance with pertinent Federal regulations and plans, appropriate interagency agreements, and international conventions.

The emergency management program is implemented by site plans and procedures and corporate standards.

\subsection{LOCAL EMERGENCY MANUAL}

A local emergency manual is maintained for the NTF and for the South Tank Farm (Tank W-11). ${ }^{1}$ The local emergency manual familiarizes individuals working in the facility with the emergency service units and guidelines that are available and to provide a course of action to pursue in the event that an emergency condition develops. The local emergency manual contains site, as well as facility specific, emergency response actions, contact information, identification of hazard source location, and location of useful documentation. All facility personnel are to be familiar with the content and location of the local emergency manual.

\subsection{REFERENCES}

1. ORNL Local Emergency Manual, Revision 2 dated January 2, 1995. 

$10-1$

\section{MANAGEMENT, ORGANIZATION, AND INSTITUTIONAL SAFETY PROVISIONS}

\subsection{ORGANIZATION STRUCTURE}

Operations in the NTF are the direct responsibility of the NTF facility manager. The facility manager reports to the Surveillance and Maintenance Remedial Action Facility Supervisor. The Surveillance and Maintenance Remedial Action Facility Supervisor reports to the Energy Research Surveillance and Maintenance Program Manager.

The Treatability Study project is the responsibility of Energy Systems ER. Treatability Study operations are the direct responsibility of the Gunite and Associated Tanks Remediation Program Manager. Lead personnel in the areas of project integration, studies and assessments, balance of plant, Treatability Study tests, facility management, and sampling and analysis report to the Program Manager. The Program Manager reports to the Characterization and Remedial Decisions Program Manager. Oversight of the Characterization and Remediation Decisions Program is provided by the DOE ORNL ER Program Manager.

\subsection{CONFIGURATION AND DOCUMENT CONTROL}

The conduct of operations program ensures that operations at DOE facilities are managed, organized, and conducted in a manner to assure an acceptable level of safety. The GAAT Project and the NTF surveillance and maintenance activities will be performed under the control of the ITO process. ITOs provide the negotiated basis for all requirements for the subject activities including the requirements for the Health and Safety Programs. The ITO proposal will include requirements that have a configuration and document control program that accomplishes the following objectives:

- Configuration management requirements, responsibilities, and interfaces are clearly established, communicated, understood, and supported;

- Design bases or design requirements that are unavailable are identified and re-established as required to support (1) safe operation; (2) compliance with known facility, activity, process, or experiment requirements; (3) resolution of significant concerns; or (4) change control;

- Changes to CIs are properly and thoroughly analyzed, approved, implemented, and documented to ensure conformance to design and administrative requirements;

- Operational and maintenance activities are controlled to ensure that the facility, activity, process, or experiment's configuration is kept consistent with design or administrative requirements; and

- $\quad \mathrm{CI}$ documents and records are correct and readily available. 


\subsection{OCCURRENCE REPORTING}

The conduct of operations program ensures that operations at DOE facilities are managed, organized, and conducted in a manner to assure an acceptable level of safety. The GAAT Project and the NTF surveillance and maintenance activities will be performed under the control of the ITO process. ITOs provide the negotiated basis for all requirements for the subject activities including the requirements for the Health and Safety Programs. The ITO proposal will include requirements that have an occurrence reporting program that accomplishes the following objectives:

- Identifying and documenting abnormal events,

- $\quad$ Reporting procedure to DOE,

- Developing and implementing of corrective actions, and

- Communicating lessons learned.

\subsection{REFERENCES}

1. ORNL/ER-348, Configuration Management Plan for the Gunite and Associated Tanks Treatability Study, Oak Ride National Laboratory, Oak Ridge, Tennessee, Oak Ridge, Tennessee, dated April 1996. 


\section{APPENDIX A}

Hazard Identification Tables for the North Tank Farm 

Table A.1. Tank W-1

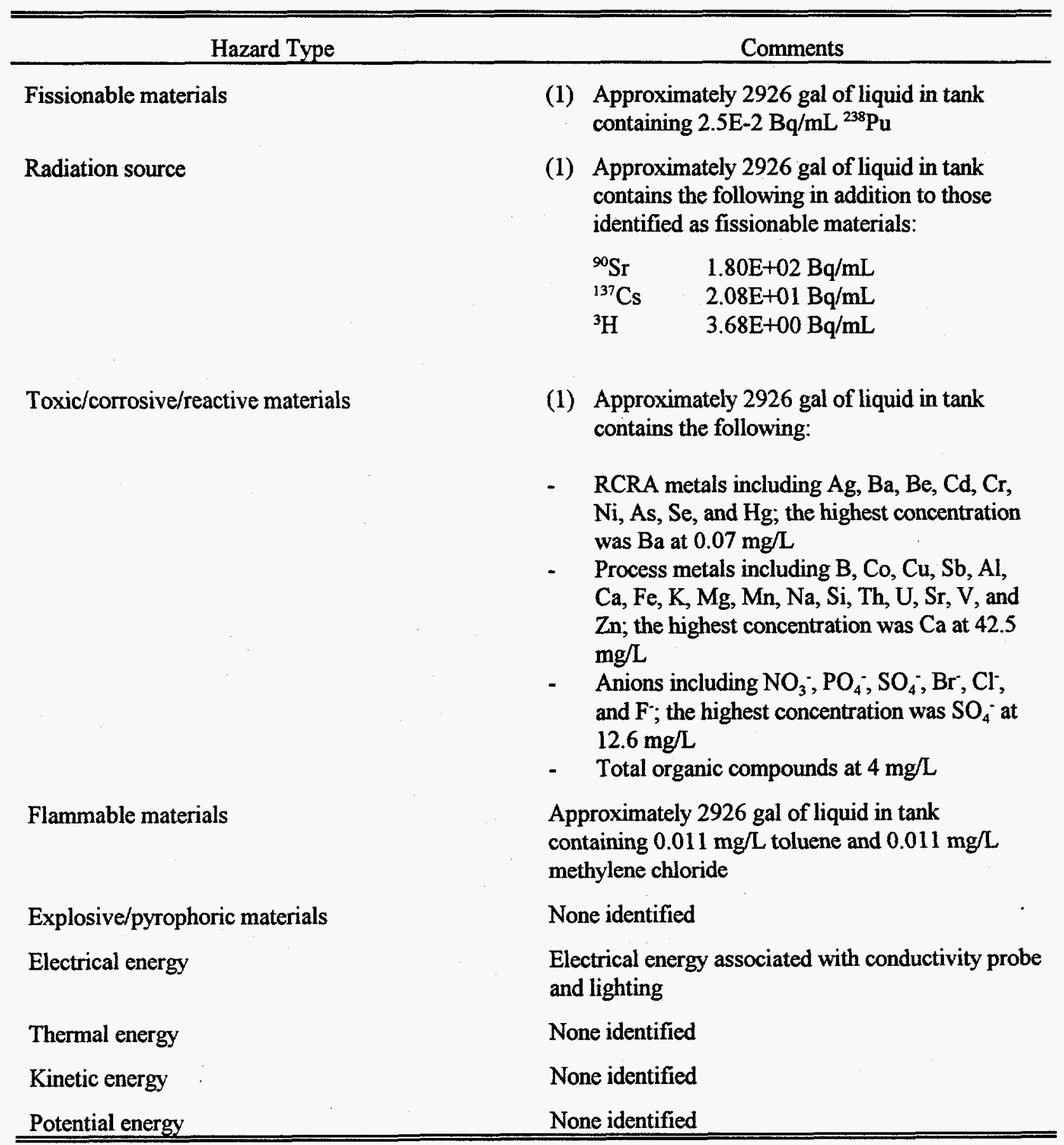


Table A.2. Tank W-1A

\begin{tabular}{cc}
\hline \hline Hazard Type & Comments \\
\hline
\end{tabular}

Fissionable materials

Radiation source
(1) Approximately 25 gal of liquid in tank containing $7.30 \mathrm{E}+2 \mathrm{~Bq} / \mathrm{mL}^{233} \mathrm{U}, 1.90 \mathrm{E}+1$ $\mathrm{Bq} / \mathrm{mL}^{238} \mathrm{Pu}, 6.70 \mathrm{E}+1 \mathrm{~Bq} / \mathrm{mL}^{239} \mathrm{Pu}$, and $9.00 \mathrm{E}+0 \mathrm{~Bq} / \mathrm{mL}^{244} \mathrm{Cm}$

Note: Tank W-1A collects approximately 1750 gal per month from inleakage (mainly rainwater) and is emptied periodically. No additional radioactive materials have been added to it since it was removed from service in 1986 . It is assumed that there are $\mathbf{2 5}$ gal of liquid in the tank at the concentrations that were present the last time the tank was sampled (reported in ORNL/ER-13)

(1) Approximately 25 gal of liquid in tank contains the following in addition to those identified as fissionable materials:

$\begin{array}{ll}{ }^{90} \mathrm{Sr} & 3.20 \mathrm{E}+02 \mathrm{~Bq} / \mathrm{mL} \\ { }^{137} \mathrm{Cs} & 1.40 \mathrm{E}+02 \mathrm{~Bq} / \mathrm{mL} \\ { }^{60} \mathrm{Co} & 4.40 \mathrm{E}+00 \mathrm{~Bq} / \mathrm{mL} \\ { }^{3} \mathrm{H} & 2.60 \mathrm{E}+00 \mathrm{~Bq} / \mathrm{mL} \\ { }^{238} \mathrm{U} & 5.00 \mathrm{E}+00 \mathrm{~Bq} / \mathrm{mL} \\ { }^{241} \mathrm{Am} & 5.40 \mathrm{E}+01 \mathrm{~Bq} / \mathrm{mL} \\ { }^{134} \mathrm{Cs} & 4.60 \mathrm{E}+00 \mathrm{~Bq} / \mathrm{mL} \\ { }^{232} \mathrm{U} & 2.70 \mathrm{E}+02 \mathrm{~Bq} / \mathrm{mL}\end{array}$

Note: Tank W-1A collects approximately 1750 gal per month from inleakage (mainly rainwater) and is emptied periodically. No additional radioactive materials have been added to it since it was removed from service in 1986. It is assumed that there are $\mathbf{2 5}$ gal of liquid in the tank at the concentrations that were present the last time the tank was sampled (reported in ORNL/ER-13) 
Table A-2. Tank W-1A (continued)

\begin{tabular}{|c|c|}
\hline Hazard Type & Comments \\
\hline \multirow[t]{2}{*}{ Toxic/corrosive/reactive materials } & $\begin{array}{l}\text { (1) Approximately } 25 \text { gal of liquid in tank } \\
\text { contains the following: }\end{array}$ \\
\hline & $\begin{array}{l}\text { - } \quad \text { RCRA metals including } \mathrm{Ag}, \mathrm{Ba}, \mathrm{Be}, \mathrm{Cd}, \mathrm{Cr} \text {, } \\
\mathrm{Ni}, \mathrm{As}, \mathrm{Se} \text {, and } \mathrm{Hg} \text {; the highest concentration } \\
\text { was } \mathrm{Cd} \text { at } 7.3 \mathrm{mg} / \mathrm{L} \text {. } \\
\text { - } \\
\text { Process metals including } \mathrm{U} \text { at } 477 \mathrm{mg} / \mathrm{L} \text {. } \\
\text { - Anions including } \mathrm{NO}_{3}^{-}, \mathrm{PO}_{4}^{-}, \mathrm{SO}_{4}^{-}, \mathrm{Cl}^{-} \text {, and } \mathrm{F} \text {; } \\
\text { the highest concentration was } \mathrm{SO}_{4}^{-} \text {at } 58.0 \\
\mathrm{mg} / \mathrm{L}\end{array}$ \\
\hline Flammable materials & $\begin{array}{l}\text { Approximately } 25 \text { gal of liquid in tank containing } \\
0.063 \mathrm{mg} / \mathrm{L} \text { toluene, } 0.02 \mathrm{mg} / \mathrm{L} \text { trichloroethylene, } \\
0.004 \mathrm{mg} / \mathrm{L} \text { methylene chloride, and } 7 \mathrm{mg} / \mathrm{L} \\
\text { methanol }\end{array}$ \\
\hline Explosive/pyrophoric materials & None identified \\
\hline Electrical energy & Electrical energy associated with lighting \\
\hline Thermal energy & None identified \\
\hline Kinetic energy & None identified \\
\hline Potential energy & Compressed air associated with instrumentation \\
\hline
\end{tabular}


Table A.3. Tank W-2

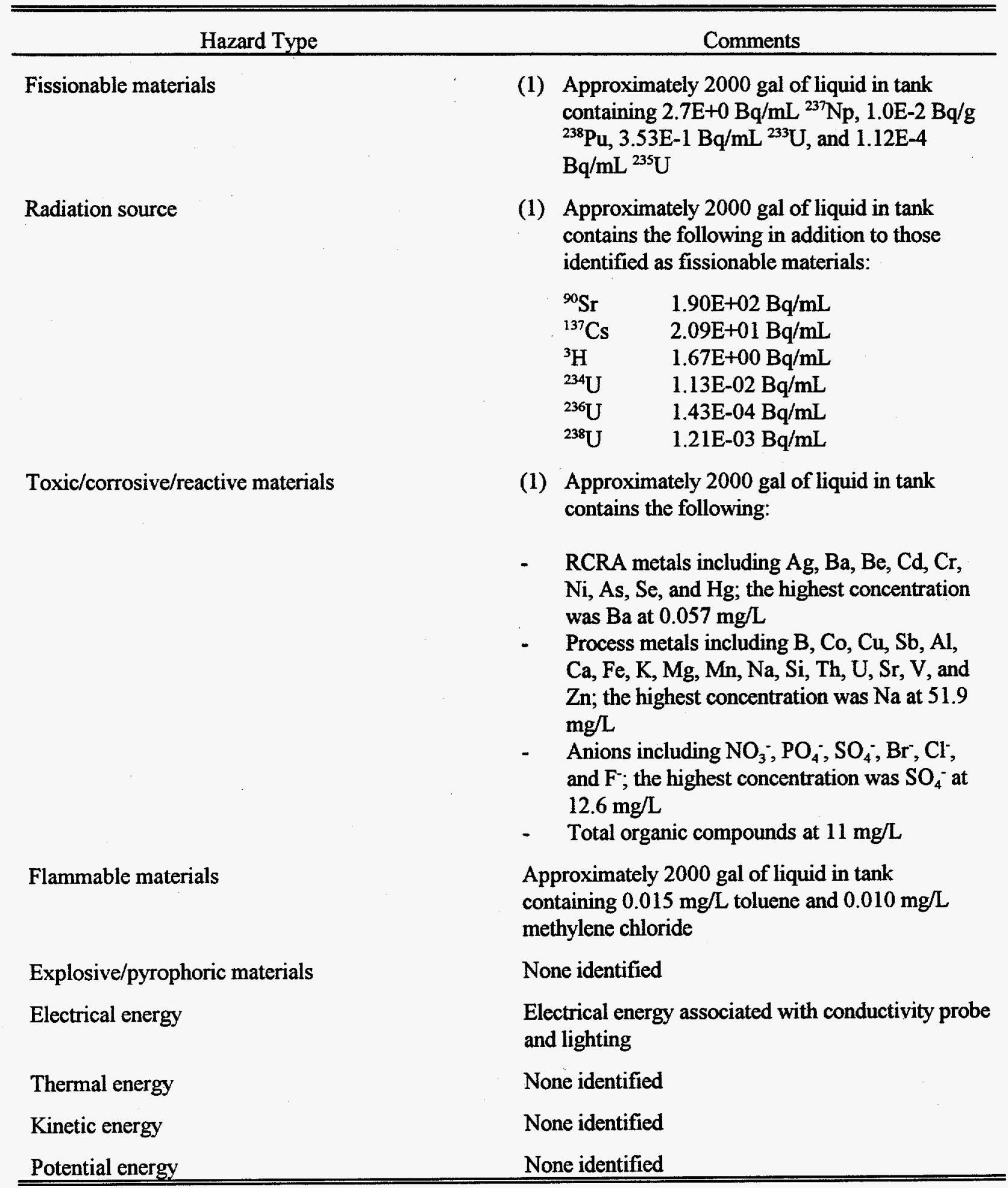


Table A.4. Tank W-3

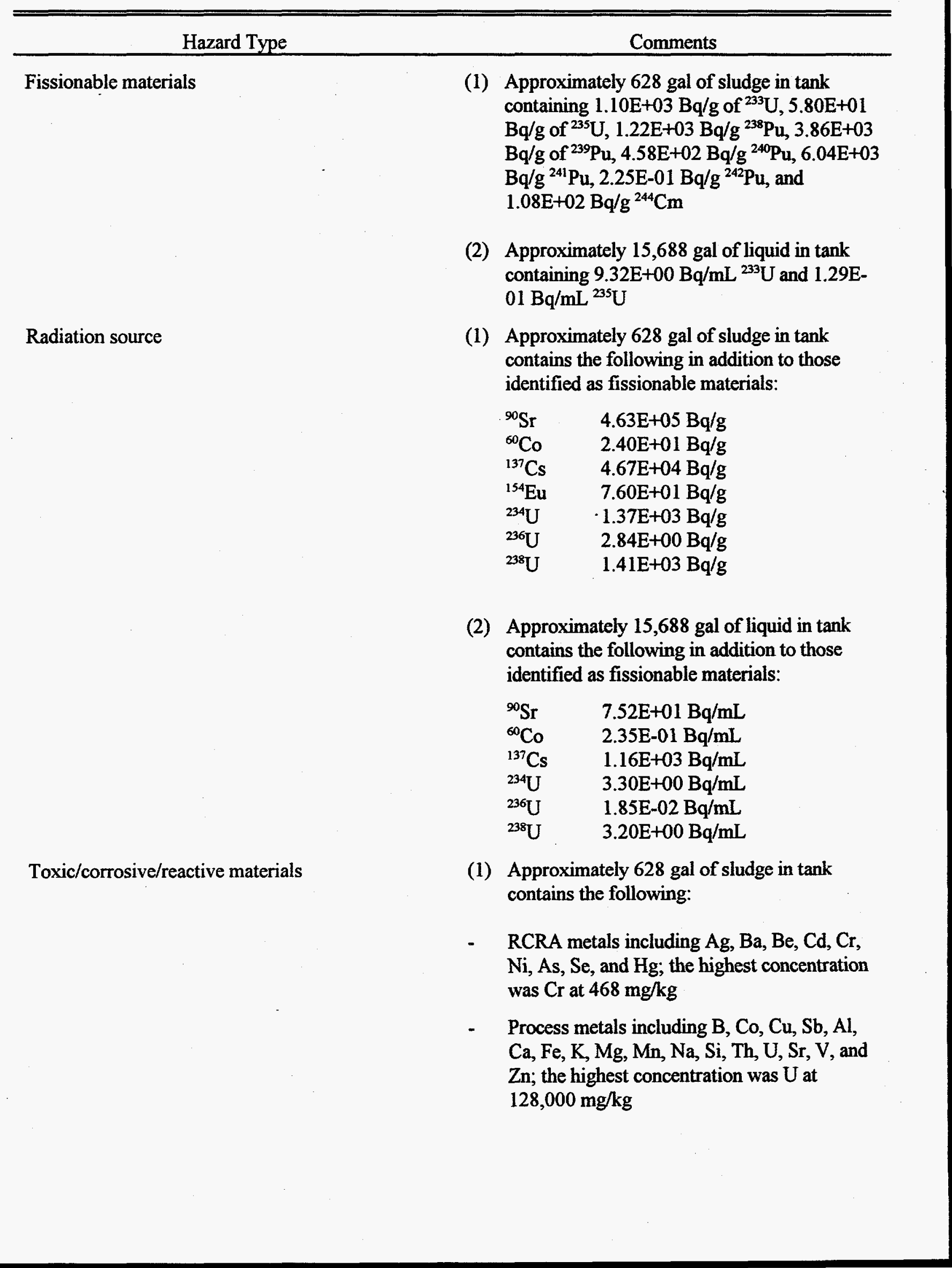


Table A-4. Tank W-3 (continued)

\begin{tabular}{|c|c|}
\hline Hazard Type & Comments \\
\hline & $\begin{array}{l}\text { - Anions including } \mathrm{NO}_{3}^{-}, \mathrm{PO}_{4}^{-}, \mathrm{SO}_{4}^{-}, \mathrm{Br}^{-}, \mathrm{Cl}^{-} \\
\text {and } \mathrm{F}^{-} ; \text {the highest concentration was } \mathrm{PO}_{4}^{-} \text {at } \\
3,240 \mathrm{mg} / \mathrm{kg}\end{array}$ \\
\hline & - Total organic compounds at $5300 \mathrm{mg} / \mathrm{kg}$ \\
\hline & $\begin{array}{l}\text { (2) Approximately } 15,688 \text { gal of liquid in tank } \\
\text { contains the following: }\end{array}$ \\
\hline & $\begin{array}{l}\text { RCRA metals including } \mathrm{Ag}, \mathrm{Ba}, \mathrm{Be}, \mathrm{Cd}, \mathrm{Cr} \text {, } \\
\mathrm{Ni}, \mathrm{As}, \mathrm{Se} \text {, and } \mathrm{Hg} \text {; the highest concentration } \\
\text { was } \mathrm{Cr} \text { at } 10.5 \mathrm{mg} / \mathrm{L}\end{array}$ \\
\hline & $\begin{array}{l}\text { Process metals including } \mathrm{B}, \mathrm{Co}, \mathrm{Cu}, \mathrm{Sb}, \mathrm{Al} \text {, } \\
\mathrm{Ca}, \mathrm{Fe}, \mathrm{K}, \mathrm{Mg}, \mathrm{Mn}, \mathrm{Na}, \mathrm{Si}, \mathrm{Th}, \mathrm{U}, \mathrm{Sr}, \mathrm{V}, \text { and } \\
\mathrm{Zn} ; \text { the highest concentration was } \mathrm{Na} \text { at } 2,360 \\
\mathrm{mg} / \mathrm{L}\end{array}$ \\
\hline & $\begin{array}{l}\text { Anions including } \mathrm{NO}_{3}^{-}, \mathrm{PO}_{4}^{-}, \mathrm{SO}_{4}^{-}, \mathrm{Br}^{-}, \mathrm{Cl}^{-} \\
\text {and } \mathrm{F} ; \text { the highest concentration was } \mathrm{PO}_{4}^{-} \text {at } \\
674 \mathrm{mg} / \mathrm{L}\end{array}$ \\
\hline & - Total organic compounds at $197 \mathrm{mg} / \mathrm{L}$ \\
\hline Flammable materials & $\begin{array}{l}\text { Waste in tank containing } 0.037 \mathrm{mg} / \mathrm{L} \text { toluene, } \\
0.014 \mathrm{mg} / \mathrm{L} \text { trichloroethylene, } 0.008 \mathrm{mg} / \mathrm{L} \\
\text { chlorobenzene, } 0.023 \mathrm{mg} / \mathrm{L} \text { methylene chloride, } \\
0.004 \mathrm{mg} / \mathrm{L} \text { tetrachloroethylene, } 5 \mathrm{mg} / \mathrm{L} \text { methyl } \\
\text { ethyl ketone, } 7 \mathrm{mg} / \mathrm{L} \text { acetone, } 40 \mathrm{mg} / \mathrm{L} \text { methanol, } \\
\text { and } 7 \mathrm{mg} / \mathrm{L} \text { n-butyl alcohol }\end{array}$ \\
\hline Explosive/pyrophoric materials & None identified \\
\hline Electrical energy & None identified \\
\hline Thermal energy & None identified \\
\hline Kinetic energy & None identified \\
\hline Potential energy & None identified \\
\hline
\end{tabular}




\begin{tabular}{|c|c|c|}
\hline Hazard Type & \multicolumn{2}{|r|}{ Comments } \\
\hline \multirow[t]{2}{*}{ Fissionable materials } & $\begin{array}{l}\text { (1) Appro } \\
\text { conta } \\
\mathrm{Bq} / \mathrm{g} \\
7.96 \mathrm{E} \\
{ }^{240} \mathrm{Pu} \\
\text { of }^{242} \mathrm{I}\end{array}$ & $\begin{array}{l}\text { ately } 1313 \text { gal of sludge in tank } \\
5.33 \mathrm{E}+02 \mathrm{~Bq} / \mathrm{g} \text { of } \\
\mathrm{U}, 4.67 \mathrm{E}+02 \mathrm{~Bq}, 9.97 \mathrm{~g} \text { of }{ }^{238} \mathrm{Pu} \\
\mathrm{Bq} / \mathrm{g} \text { of } \\
\mathrm{E}+03 \mathrm{~Bq} / \mathrm{gu} \text { of } 9.50 \mathrm{E}+02 \mathrm{~Bq} / \mathrm{gu} \text { of } \\
\text { nd } 2.10 \mathrm{E}-01 \mathrm{~Bq} / \mathrm{g}+02 \mathrm{~Bq} / \mathrm{g} \text { of }{ }^{244} \mathrm{Cm}\end{array}$ \\
\hline & $\begin{array}{l}\text { (2) Appro } \\
\text { conta } \\
5.97 \mathrm{E}\end{array}$ & $\begin{array}{l}\text { ately } 29,754 \text { gal of liquid in tank } \\
1.54 \mathrm{E}+00 \mathrm{~Bq} / \mathrm{mL} \text { of }{ }^{233} \mathrm{U} \text { and } \\
\mathrm{Bq} / \mathrm{mL} \text { of }{ }^{235} \mathrm{U}\end{array}$ \\
\hline \multirow[t]{4}{*}{ Radiation source } & \multicolumn{2}{|c|}{$\begin{array}{l}\text { Approximately } 1313 \text { gal of sludge in tank } \\
\text { contains the following in addition to those } \\
\text { identified as fissionable materials: }\end{array}$} \\
\hline & $\begin{array}{l}{ }^{90} \mathrm{Sr} \\
{ }^{60} \mathrm{Co} \\
{ }^{137} \mathrm{Cs} \\
{ }^{234} \mathrm{U} \\
{ }^{236} \mathrm{U} \\
{ }^{238} \mathrm{U}\end{array}$ & $\begin{array}{l}2.11 \mathrm{E}+05 \mathrm{~Bq} / \mathrm{g} \\
1.20 \mathrm{E}+01 \mathrm{~Bq} / \mathrm{g} \\
2.69 \mathrm{E}+05 \mathrm{~Bq} / \mathrm{g} \\
2.58 \mathrm{E}+03 \mathrm{~Bq} / \mathrm{g} \\
5.60 \mathrm{E}+00 \mathrm{~Bq} / \mathrm{g} \\
2.43 \mathrm{E}+03 \mathrm{~Bq} / \mathrm{g}\end{array}$ \\
\hline & \multicolumn{2}{|c|}{$\begin{array}{l}\text { Approximately } 29,754 \text { gal of liquid in tank } \\
\text { contains the following in addition to those } \\
\text { identified as fissionable materials: }\end{array}$} \\
\hline & $\begin{array}{l}{ }^{90} \mathrm{Sr} \\
{ }^{60} \mathrm{Co} \\
{ }^{137} \mathrm{Cs} \\
{ }^{234} \mathrm{U} \\
{ }^{236} \mathrm{U}\end{array}$ & $\begin{array}{l}2.97 \mathrm{E}+03 \mathrm{~Bq} / \mathrm{mL} \\
1.28 \mathrm{E}+02 \mathrm{~Bq} / \mathrm{mL} \\
1.58 \mathrm{E}+04 \mathrm{~Bq} / \mathrm{mL} \\
1.47 \mathrm{E}+01 \mathrm{~Bq} / \mathrm{mL} \\
7.47 \mathrm{E}-02 \mathrm{~Bq} / \mathrm{mL} \\
1.49 \mathrm{E}+01 \mathrm{~Bq} / \mathrm{mL}\end{array}$ \\
\hline \multirow[t]{4}{*}{ Toxic/corrosive/reactive materials } & \multicolumn{2}{|c|}{$\begin{array}{l}\text { Approximately } 1313 \text { gal of sludge in tank } \\
\text { contains the following: }\end{array}$} \\
\hline & \multicolumn{2}{|c|}{$\begin{array}{l}\mathrm{RCRA} \text { metals including } \mathrm{Ag}, \mathrm{Ba}, \mathrm{Be}, \mathrm{Cd}, \mathrm{Cr} \text {, } \\
\mathrm{Ni}, \mathrm{As}, \mathrm{Se} \text {, and } \mathrm{Hg} \text {; the highest concentration } \\
\text { was } \mathrm{Cr} \text { at } 316 \mathrm{mg} / \mathrm{kg}\end{array}$} \\
\hline & \multicolumn{2}{|c|}{$\begin{array}{l}\text { Process metals include } \mathrm{B}, \mathrm{Co}, \mathrm{Cu}, \mathrm{Sr}, \mathrm{V}, \mathrm{Sb} \text {, } \\
\mathrm{Si}, \mathrm{Th}, \mathrm{U}, \mathrm{Al}, \mathrm{Ca}, \mathrm{Fe}, \mathrm{K}, \mathrm{Mg}, \mathrm{Mn}, \mathrm{Na} \text {, and } \mathrm{Zn} \text {; } \\
\text { the highest concentration was } \mathrm{U} \text { at } 211,000 \\
\mathrm{mg} / \mathrm{kg}\end{array}$} \\
\hline & \multicolumn{2}{|c|}{$\begin{array}{l}\text { Anions including } \mathrm{NO}_{3}^{-}, \mathrm{PO}_{4}^{-}, \mathrm{SO}_{4}^{-}, \mathrm{Br}^{-}, \mathrm{Cl}_{-}^{-} \\
\text {and } \mathrm{F} ; \text { the highest concentration was } \mathrm{PO}_{4}^{-} \text {at } \\
3070 \mathrm{mg} / \mathrm{kg}\end{array}$} \\
\hline
\end{tabular}


Table A-5. Tank W-4 (continued)

\begin{tabular}{|c|c|}
\hline Hazard Type & Comments \\
\hline & - Total organic compounds at $200 \mathrm{mg} / \mathrm{kg}$ \\
\hline & $\begin{array}{l}\text { (2) Approximately } 29,754 \text { gal of liquid in tank } \\
\text { contains the following: }\end{array}$ \\
\hline & $\begin{array}{l}\mathrm{RCRA} \text { metals including } \mathrm{Ag}, \mathrm{Ba}, \mathrm{Be}, \mathrm{Cd}, \mathrm{Cr} \text {, } \\
\mathrm{Ni}, \mathrm{As}, \mathrm{Se} \text {, and } \mathrm{Hg} \text {; the highest concentration } \\
\text { was } \mathrm{Cr} \text { at } 6.95 \mathrm{mg} / \mathrm{L}\end{array}$ \\
\hline & $\begin{array}{l}\text { Process metals include } \mathrm{B}, \mathrm{Co}, \mathrm{Cu}, \mathrm{Sr}, \mathrm{V}, \mathrm{Sb} \\
\mathrm{Si}, \mathrm{Th}, \mathrm{U}, \mathrm{Al}, \mathrm{Ca}, \mathrm{Fe}, \mathrm{K}, \mathrm{Mg}, \mathrm{Mn}, \mathrm{Na} \text { and } \mathrm{Zn} \text {; } \\
\text { the highest concentration was } \mathrm{Na} \text { at } 220,000 \\
\mathrm{mg} / \mathrm{L}\end{array}$ \\
\hline & $\begin{array}{l}\text { - Anions including } \mathrm{NO}_{3}^{-}, \mathrm{PO}_{4}^{-}, \mathrm{SO}_{4}^{-}, \mathrm{Br}^{-}, \mathrm{Cl}^{-} \\
\text {and } \mathrm{F} \text {; the highest concentration was } \mathrm{NO}_{3}^{-} \text {at } \\
1,580 \mathrm{mg} / \mathrm{L}\end{array}$ \\
\hline & - Total organic compounds at $15 \mathrm{mg} / \mathrm{L}$ \\
\hline Flammable materials & $\begin{array}{l}\text { Waste in tank containing } 0.046 \mathrm{mg} / \mathrm{L} \text { toluene, } \\
0.010 \mathrm{mg} / \mathrm{L} \text { methylene chloride, } 0.014 \mathrm{mg} / \mathrm{L} \\
\text { trichloroethylene, } 7 \mathrm{mg} / \mathrm{L} \text { methyl isobutyl ketone, } \\
11 \mathrm{mg} / \mathrm{L} \text { ethyl hexyl phthalate, and } 2.1 \mathrm{mg} / \mathrm{L} \\
\text { dibutyl phthalate }\end{array}$ \\
\hline Explosive/pyrophoric materials & None identified \\
\hline Electrical energy & None identified \\
\hline Thermal energy & None identified \\
\hline Kinetic energy & None identified \\
\hline Potential energy & None identified \\
\hline
\end{tabular}




\begin{tabular}{|c|c|}
\hline Hazard Type & Comments \\
\hline \multirow[t]{2}{*}{ Fissionable materials } & $\begin{array}{l}\text { (1) Approximately } 25 \mathrm{gal} \text { of liquid in tank } \\
\text { containing } 5.5 \mathrm{E}+2 \mathrm{~Bq} / \mathrm{mL}{ }^{238} \mathrm{Pu} \text { and } 6.90 \mathrm{E}+1 \\
\mathrm{~Bq} / \mathrm{mL}^{239} \mathrm{Pu}\end{array}$ \\
\hline & $\begin{array}{l}\text { Note: Tank W-13 was emptied in } 1992 \text {. It is } \\
\text { assumed that approximately } 25 \text { gal of residual } \\
\text { liquid remains in the tank at the sampled } \\
\text { concentrations }\end{array}$ \\
\hline \multirow[t]{3}{*}{ Radiation source } & $\begin{array}{l}\text { (1) Approximately } 25 \text { gal of liquid in tank } \\
\text { contains the following in addition to those } \\
\text { identified as fissionable materials: }\end{array}$ \\
\hline & $\begin{array}{ll}{ }^{90} \mathrm{Sr} & 5.90 \mathrm{E}+05 \mathrm{~Bq} / \mathrm{mL} \\
{ }^{137} \mathrm{Cs} & 6.10 \mathrm{E}+05 \mathrm{~Bq} / \mathrm{mL} \\
{ }^{60} \mathrm{Co} & 1.90 \mathrm{E}+02 \mathrm{~Bq} / \mathrm{mL} \\
{ }^{3} \mathrm{H} & 2.80 \mathrm{E}+03 \mathrm{~Bq} / \mathrm{mL} \\
{ }^{228} \mathrm{Th} /{ }^{232} \mathrm{Th} & 1.30 \mathrm{E}+02 \mathrm{~Bq} / \mathrm{mL} \\
{ }^{154} \mathrm{Eu} & 1.60 \mathrm{E}+03 \mathrm{~Bq} / \mathrm{mL}\end{array}$ \\
\hline & $\begin{array}{l}\text { Note: Tank W- } 13 \text { was emptied in } 1992 \text {. It is } \\
\text { assumed that approximately } 25 \text { gal of residual } \\
\text { liquid remains in the tank at the sampled } \\
\text { concentrations }\end{array}$ \\
\hline \multirow[t]{2}{*}{ Toxic/corrosive/reactive materials } & $\begin{array}{l}\text { (1) Approximately } 25 \text { gal of liquid in tank } \\
\text { contains the following: }\end{array}$ \\
\hline & $\begin{array}{l}\text { - } \mathrm{RCRA} \text { metals including } \mathrm{Ag}, \mathrm{Ba}, \mathrm{Be}, \mathrm{Cd}, \mathrm{Cr} \text {, } \\
\mathrm{Ni}, \mathrm{As}, \mathrm{Se} \text {, and } \mathrm{Hg} \text {; the highest concentration } \\
\text { was } \mathrm{Hg} \text { at } 35 \mathrm{mg} / \mathrm{L} \\
\text { - } \\
\text { - } \\
\text { Process metals including } \mathrm{U} \text { at } 18.8 \mathrm{mg} / \mathrm{L} \text {. } \\
\text { and } \mathrm{F}^{-} \text {; the highest concentration was } \mathrm{NO}_{3}^{-} \text {at } \\
43.0 \mathrm{mg} / \mathrm{L} \\
\text { - Total organic compounds at } 41.4 \mathrm{mg} / \mathrm{L}\end{array}$ \\
\hline Flammable materials & $\begin{array}{l}\text { Approximately } 25 \text { gal of liquid in tank containing } \\
0.1 \mathrm{mg} / \mathrm{L} \text { toluene, } 0.004 \mathrm{mg} / \mathrm{L} \text { chlorobenzene, } \\
0.024 \mathrm{mg} / \mathrm{L} \text { methylene chloride, and } 11 \mathrm{mg} / \mathrm{L} \\
\text { methanol }\end{array}$ \\
\hline Explosive/pyrophoric materials & None identified \\
\hline Electrical energy & Electrical energy associated with lighting \\
\hline Thermal energy & None identified \\
\hline
\end{tabular}


A-12

Table A-6. Tank W-13 (continued)

\begin{tabular}{lll}
\hline \hline & Hazard Type & Comments \\
\hline Kinetic energy & None identified & \\
Potential energy & None identified \\
\hline \hline
\end{tabular}


Table A.7. Tank W-14

\begin{tabular}{|c|c|}
\hline Hazard Type & Comments \\
\hline Fissionable materials & (1) None identified. \\
\hline \multirow[t]{3}{*}{ Radiation source } & $\begin{array}{l}\text { (1) Approximately } 25 \text { gal of liquid in tank } \\
\text { contains the following: }\end{array}$ \\
\hline & $\begin{array}{ll}{ }^{90} \mathrm{Sr} & 4.30 \mathrm{E}+05 \mathrm{~Bq} / \mathrm{mL} \\
{ }^{137} \mathrm{Cs} & 4.10 \mathrm{E}+05 \mathrm{~Bq} / \mathrm{mL} \\
{ }^{60} \mathrm{Co} & 1.10 \mathrm{E}+03 \mathrm{~Bq} / \mathrm{mL} \\
{ }^{3} \mathrm{H} & 3.00 \mathrm{E}+00 \mathrm{~Bq} / \mathrm{mL} \\
{ }^{228} \mathrm{Th} /{ }^{32} \mathrm{Th} & 8.00 \mathrm{E}+03 \mathrm{~Bq} / \mathrm{mL}\end{array}$ \\
\hline & $\begin{array}{l}\text { Note: Tank W-14 was emptied in } 1992 \text {. It is } \\
\text { assumed that approximately } 25 \text { gal of residual } \\
\text { liquid remains in the tank at the sampled } \\
\text { concentrations }\end{array}$ \\
\hline \multirow[t]{2}{*}{ Toxic/corrosive/reactive materials } & $\begin{array}{l}\text { (1) Approximately } 25 \text { gal of liquid in tank } \\
\text { contains the following: }\end{array}$ \\
\hline & $\begin{array}{l}\text { - } \mathrm{RCRA} \text { metals including } \mathrm{Ag}, \mathrm{Ba}, \mathrm{Be}, \mathrm{Cd}, \mathrm{Cr} \text {, } \\
\mathrm{Ni}, \mathrm{As}, \mathrm{Se} \text {, and } \mathrm{Hg} \text {; the highest concentration } \\
\text { was } \mathrm{Cr} \text { at } 64 \mathrm{mg} / \mathrm{L} \\
\text { - } \quad \text { Process metals including } \mathrm{U} \text { at } 0.56 \mathrm{mg} / \mathrm{L} \\
\text { - } \quad \text { Anions including } \mathrm{NO}_{3}^{-}, \mathrm{PO}_{4}^{-}, \mathrm{SO}_{4}^{-}, \mathrm{Br}^{-}, \mathrm{Cl} \text {, } \\
\text { and } \mathrm{F}^{-} \text {; the highest concentration was } \mathrm{NO}_{3}^{-} \text {at } \\
70.0 \mathrm{mg} / \mathrm{L} \\
\text { - Total organic compounds at } 132 \mathrm{mg} / \mathrm{L}\end{array}$ \\
\hline Flammable materials & $\begin{array}{l}\text { Approximately } 25 \text { gal of liquid in tank containing } \\
0.021 \mathrm{mg} / \mathrm{L} \text { toluene, } 0.006 \mathrm{mg} / \mathrm{L} \text { chlorobenzene, } \\
0.023 \mathrm{mg} / \mathrm{L} \text { methylene chloride, } 0.005 \mathrm{mg} / \mathrm{L} \\
\text { tetrachloroethylene, } 0.006 \mathrm{mg} / \mathrm{L} \text { trichloroethylene, } \\
\text { and } 15 \mathrm{mg} / \mathrm{L} \text { methanol }\end{array}$ \\
\hline Explosive/pyrophoric materials & None identified \\
\hline Electrical energy & Electrical energy associated with lighting \\
\hline Thermal energy & None identified \\
\hline Kinetic energy & None identified \\
\hline Potential energy & None identified \\
\hline
\end{tabular}




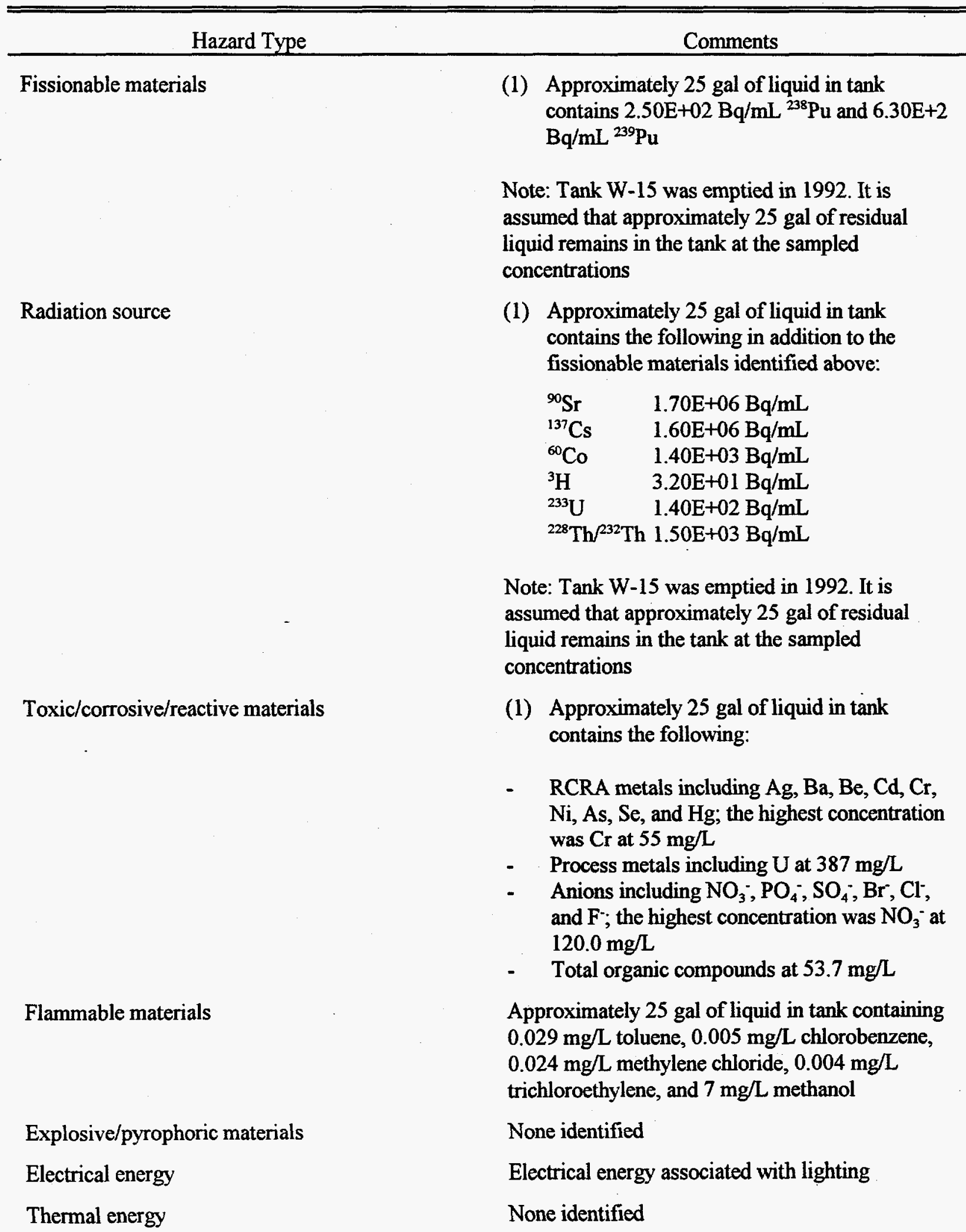




\section{A-15}

Table A-8. Tank W-15 (continued)

\begin{tabular}{lll}
\hline \hline & Hazard Type & Comments \\
\hline Kinetic energy & None identified \\
Potential energy & None identified \\
\hline \hline
\end{tabular}



APPENDIX B

Tank W-11 Hazard Identification Tables 


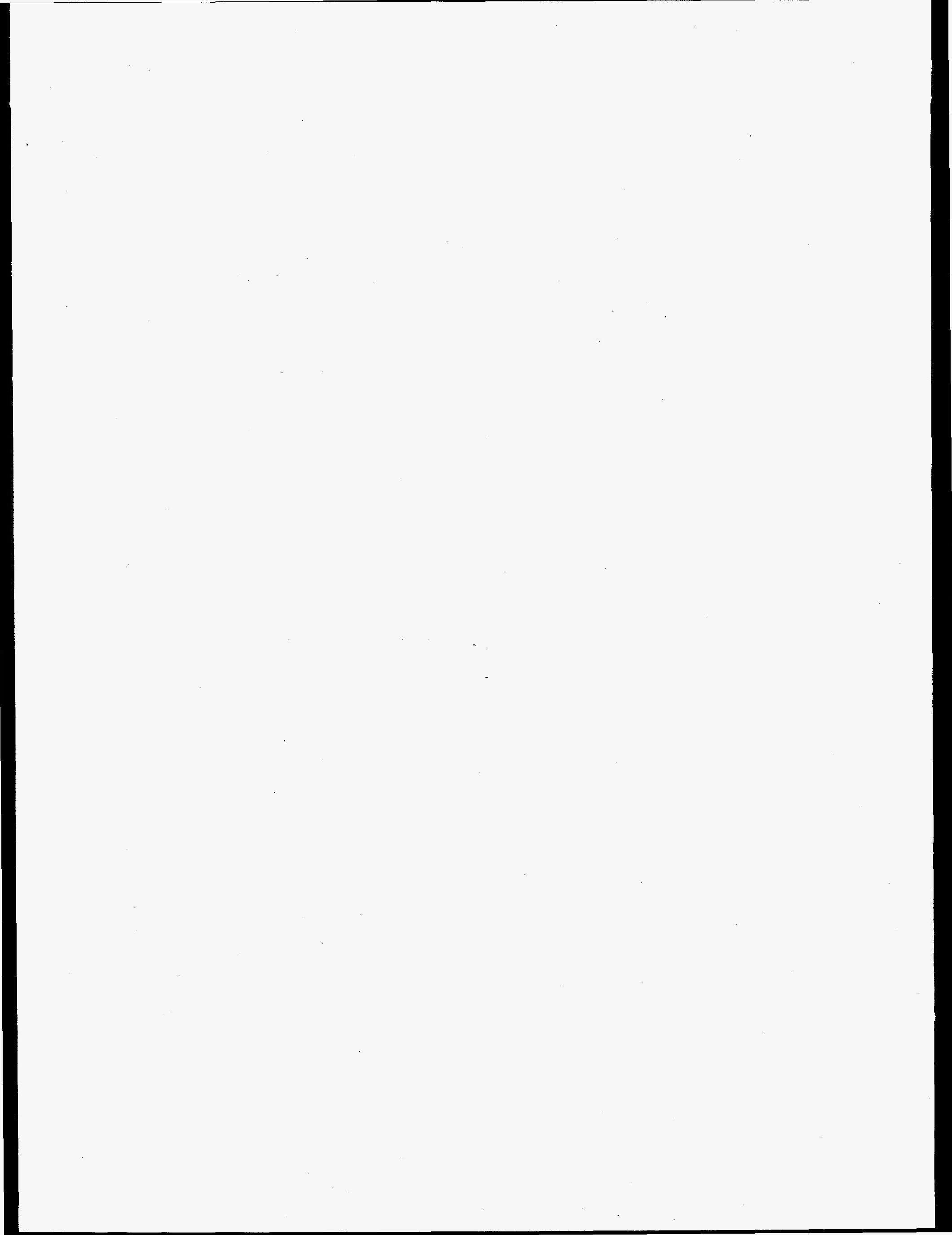

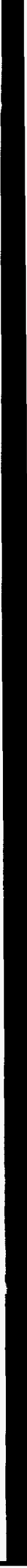




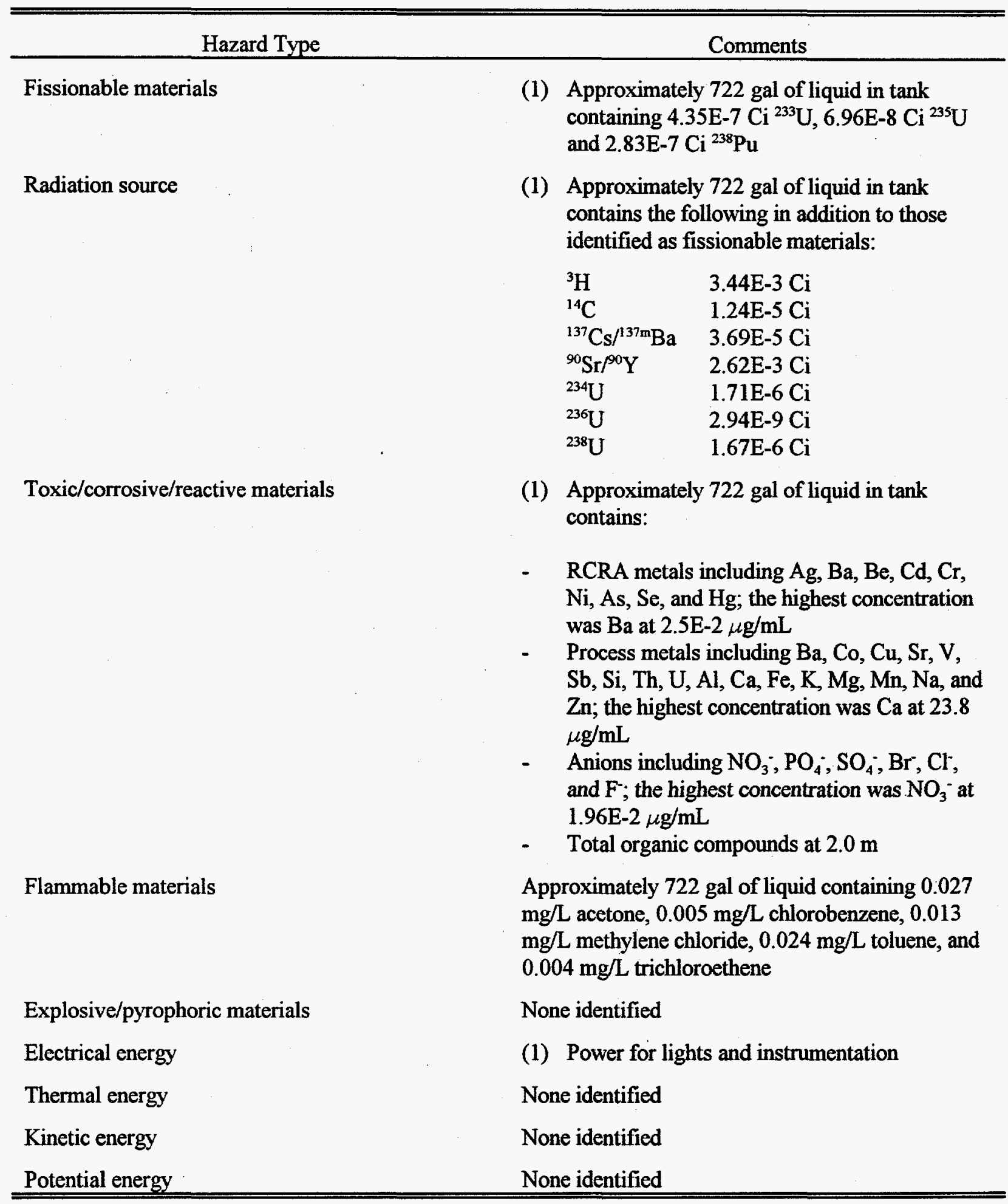




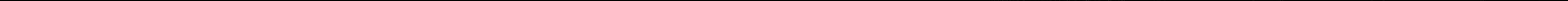


APPENDIX C

Treatability Study Hazard Identification Tables 


\begin{tabular}{|c|c|c|}
\hline Hazard Type & & Comments \\
\hline Fissionable materials & (1) & $\begin{array}{l}\text { Contamination on ventilation ducts and HEPA } \\
\text { filters. Contents of Tanks W-3 and W-4 } \\
\text { transferred through piping. See Tables A-4 } \\
\text { and A-5 for radioactive material } \\
\text { concentrations in supernate and sludge }\end{array}$ \\
\hline Radiation source & (1) & $\begin{array}{l}\text { Contamination on ventilation ducts and HEPA } \\
\text { filters. Contents of Tanks W-3 and W-4 } \\
\text { transferred through piping. See Tables A-4 } \\
\text { and A-5 for radioactive material } \\
\text { concentrations in supernate and sludge }\end{array}$ \\
\hline Toxic/corrosive/reactive materials & (1) & $\begin{array}{l}\text { Contamination on ventilation ducts and HEPA } \\
\text { filters. Contents of Tanks W-3 and W-4 } \\
\text { transferred through piping. See Tables A-4 } \\
\text { and A-5 for hazardous chemical } \\
\text { concentrations in supernate and sludge }\end{array}$ \\
\hline Flammable materials & \multicolumn{2}{|c|}{ None identified } \\
\hline Explosive/pyrophoric materials & \multicolumn{2}{|c|}{ None identified } \\
\hline Electrical energy & (1) & $\begin{array}{l}\text { Up to } 480 \text { volts to operate process equipment, } \\
\text { lights, instruments, etc. }\end{array}$ \\
\hline Thermal energy & (1) & None identified \\
\hline Kinetic energy & (1) & $\begin{array}{l}\text { Pumps, fans, and compressors for MLDUA } \\
\text { and vehicle hydraulics, decontamination spray } \\
\text { rings, ventilation, and compressed air }\end{array}$ \\
\hline \multirow[t]{2}{*}{ Potential energy } & (1) & $\begin{array}{l}\text { High pressure sluice water supply (up to } 7,000 \\
\text { psig) to confined head sluicer and jet pump }\end{array}$ \\
\hline & (2) & $\begin{array}{l}\text { High pressure water supply (up to } 2,100 \text { psig) } \\
\text { to decontamination spray rings }\end{array}$ \\
\hline
\end{tabular}


Table C.2. MLDUA

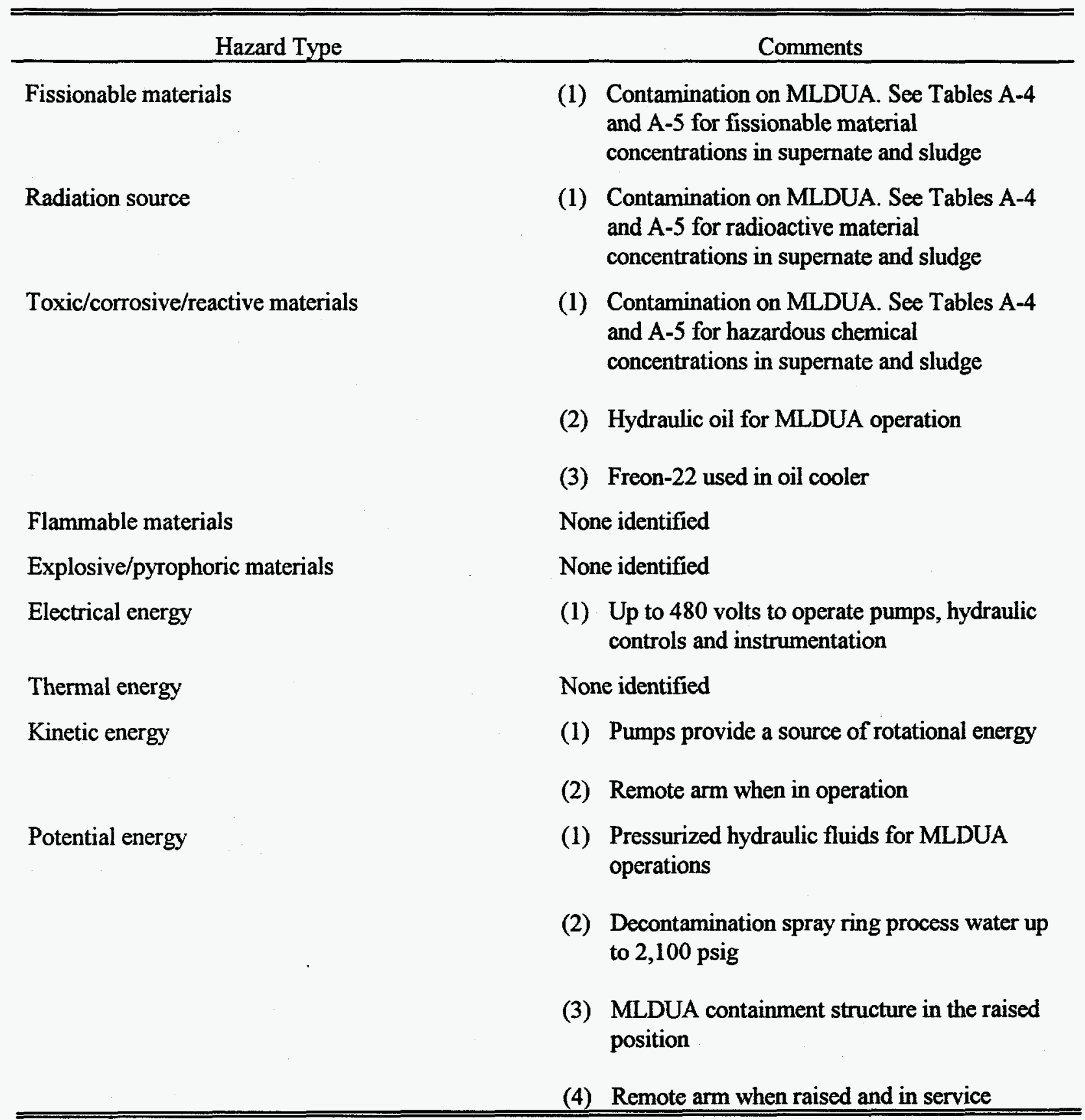


Table C.3. Remote Operated Vehicle

\begin{tabular}{|c|c|}
\hline Hazard Type & Comments \\
\hline Fissionable materials & $\begin{array}{l}\text { (1) Contamination on Remote Operated Vehicle. } \\
\text { See Tables A-4 and A-5 for fissionable } \\
\text { material concentrations in supernate and } \\
\text { sludge }\end{array}$ \\
\hline Radiation source & $\begin{array}{l}\text { (1) Contamination on Remote Operated Vehicle. } \\
\text { See Tables A-4 and A-5 for radioactive } \\
\text { material concentrations in supernate and } \\
\text { sludge }\end{array}$ \\
\hline \multirow[t]{2}{*}{ Toxic/corrosive/reactive materials } & $\begin{array}{l}\text { (1) Contamination on Remote Operated Vehicle. } \\
\text { See Tables A-4 and A-5 for hazardous } \\
\text { chemical concentrations in supernate and } \\
\text { sludge }\end{array}$ \\
\hline & (2) Hydraulic oil for vehicle operation \\
\hline Flammable materials & None identified \\
\hline Explosive/pyrophoric materials & None identified \\
\hline Electrical energy & $\begin{array}{l}\text { (1) Up to } 480 \text { volts to operate pumps, hydraulic } \\
\text { controls and instrumentation }\end{array}$ \\
\hline Thermal energy & None identified \\
\hline Kinetic energy & (1) Pumps provide a source of rotational energy \\
\hline & (2) Vehicle movement when in operation \\
\hline \multirow[t]{3}{*}{ Potential energy } & $\begin{array}{l}\text { (1) Pressurized hydraulic fluids for vehicle } \\
\text { operations }\end{array}$ \\
\hline & $\begin{array}{l}\text { (2) Decontamination spray ring process water up } \\
\text { to } 2,100 \text { psig }\end{array}$ \\
\hline & (3) Raising and lowering vehicle in tank \\
\hline
\end{tabular}


Table C.4. Decontamination Tent

\begin{tabular}{ll}
\hline \multicolumn{1}{c}{ Hazard Type } & \multicolumn{1}{c}{ Comments } \\
\hline Fissionable materials & (1) Contamination on equipment. Removed from \\
& $\begin{array}{l}\text { Tanks W-3 and W-4. See Tables A-4 and A-5 } \\
\text { for fissionable material concentrations in } \\
\text { supernate and sludge }\end{array}$ \\
Radiation source & (1) Contamination on equipment. Removed from \\
& $\begin{array}{l}\text { Tanks W-3 and W-4. See Tables A-4 and A-5 } \\
\text { for radioactive material concentrations in } \\
\text { supernate and sludge }\end{array}$ \\
Toxic/corrosive/reactive materials & (1) Contamination on equipment. Removed from \\
& $\begin{array}{l}\text { Tanks W-3 and W-4. See Tables A-4 and A-5 } \\
\text { for hazardous chemical concentrations in } \\
\text { supernate and sludge }\end{array}$ \\
Flammable materials & None identified \\
Explosive/pyrophoric materials & None identified \\
Electrical energy & (1) Up to 480 volts to operate lights and \\
Thermal energy & equipment \\
Kinetic energy & None identified \\
Potential energy & None identified \\
\hline \hline
\end{tabular}


APPENDIX D

North Tank Farm Preliminary Hazards Analysis 

D-3

\title{
PRELIMINARY HAZARDS ANALYSIS
}

\author{
AREA OF OPERATIONS: \\ North Tank Farm and Tank W-11 \\ PROCESS/OPERATION: \\ Surveillance and Maintenance Activities
}

\section{HAZARDS OF INTEREST:}

See hazard identification tables in Appendix A.

\section{SYSTEMS:}

1. Tanks W-1, W-1A, W-2, W-3, W-4, W-11, W-13, W-14, and W-15

2. Tank level monitors

3. Tank W-1A steam jet and transfer line to the LLLW System valve box 1A

4. Temporary transfer pump and hoses

5. Electrical supply

6. Steam supply

7. Process water supply

8. Compressed air supply

9. HEPA filter on vent line on Tank W-1A

\section{ENERGY SOURCES:}

1. Electrical energy associated with instrumentation and lighting

2. Thermal energy associated with the steam jets

3. Potential energy associated with compressed air supply and steam supply

\section{OPERATIONS/PROCESSES/ACTIVITIES:}

1. Tank level monitoring

2. Dry well monitoring

3. Tank liquid level management

4. Radiological surveys

5. Security inspections

6. Site inspections

7. HEPA filter maintenance and testing

8. Maintenance/Operations/Testing of equipment and site 


\section{FACILITY MODES:}

Not Applicable

\section{COMMENTS:}

The following release paths are considered in this analysis:

1) through cracks/penetrations/openings in the tank to the dry wells, liquid in dry wells flows to process waste pump station \#1 which is then pumped into the process waste system. Overflow from the process waste pump station \#1 flows to the 3524 collection basin,

2) from overfill of tanks to the dry wells, liquid in dry wells flows to process waste pump station \#1 which is then pumped into the process waste system. Overflow from the process waste pump station \#1 flows to the 3524 collection basin,

3) through cracks/penetrations/openings in the transfer piping to the outside environment,

4) from aerosols generated in the tank through openings in the tank to the outside environment. 


\begin{tabular}{|c|c|c|c|c|c|}
\hline Event & Cause: & $\begin{array}{c}\text { Prevention/Detection/ } \\
\text { Mitigation }\end{array}$ & Trequency & Consequence & Action liems: \\
\hline \multicolumn{6}{|l|}{ Tanks } \\
\hline Criticality accident & $\begin{array}{l}\text { Critical mass of fissile } \\
\text { material accumulates } \\
\text { in an unfavorable } \\
\text { geometry }\end{array}$ & $1 \mathrm{a}, 2 \mathrm{a}, 4 \mathrm{c}$ & $\begin{array}{l}\text { Beyond } \\
\text { Extremely } \\
\text { Unlikely }\end{array}$ & None & \\
\hline Fire in tank & $\begin{array}{l}\text { Combustible material } \\
\text { introduced into tank }\end{array}$ & $3 e, 4 c$ & $\begin{array}{l}\text { Extremely } \\
\text { Unlikely }\end{array}$ & $\begin{array}{l}\text { 1. Airborne release from contaminated smoke. } \\
\text { 2. No tank failure is expected }\end{array}$ & $\begin{array}{l}\text { Material in tanks is not } \\
\text { combustible }\end{array}$ \\
\hline Leak from Tank & Random failure & $\begin{array}{l}1 \mathrm{~b}, 3 \mathrm{a}, 3 \mathrm{~b}, 3 \mathrm{c}, 3 \mathrm{~d}, 3 \mathrm{~g}, 5 \mathrm{a} \\
6 \mathrm{a}\end{array}$ & Unlikely & $\begin{array}{l}\text { 1. No airborne release } \\
\text { 2. Release of up to thousands of gallons of } \\
\text { supernate with some suspended sludges to } \\
\text { the dry well and process waste system }\end{array}$ & \\
\hline Tank overfill & $\begin{array}{l}\text { Process water line } \\
\text { failure, inactive line } \\
\text { inadvertently } \\
\text { becomes connected to } \\
\text { water source } \\
\end{array}$ & $3 \mathrm{a}, 3 \mathrm{~b}, 3 \mathrm{c}, 3 \mathrm{~d}, 3 \mathrm{~g}, 5 \mathrm{a}, 6 \mathrm{a}$ & Unlikely & $\begin{array}{l}\text { 1. Airborne release possible if vent line } \\
\text { elevated above the ground } \\
\text { 2. Up to thousands of gallons of supernate } \\
\text { could be released on the ground and would } \\
\text { go to White Oak Creek }\end{array}$ & \\
\hline $\begin{array}{l}\text { Tank Dome } \\
\text { Collapse }\end{array}$ & $\begin{array}{l}\text { Random failure, } \\
\text { heavy loads }\end{array}$ & $1 \mathrm{a}, 1 \mathrm{~b}, 3 \mathrm{~g}, 4 \mathrm{~b}$ & Unlikely & $\begin{array}{l}\text { 1. Some airborne releases from falling debris } \\
\text { 2. Tank leak below water possible from falling } \\
\text { debris }\end{array}$ & \\
\hline $\begin{array}{l}\text { Aerosols in tank } \\
\text { released to } \\
\text { environment } \\
\text { (Except Tank } \\
\text { W-1A) } \\
\end{array}$ & $\begin{array}{l}\text { Aerosol generation in } \\
\text { tank }\end{array}$ & & Unlikely & $\begin{array}{l}\text { 1. Aerosols generated in tank released through } \\
\text { tank vent line to atmosphere }\end{array}$ & $\begin{array}{l}\text { Only small amounts of } \\
\text { aerosols could be generated } \\
\text { from the NTF and W-11 } \\
\text { surveillance and maintenance } \\
\text { activities }\end{array}$ \\
\hline
\end{tabular}




\begin{tabular}{|c|c|c|c|c|c|}
\hline Event & Cause & Proventionipetection' & Frequency & Conseguence & Kcrion Itens) \\
\hline \multicolumn{6}{|l|}{ Transfer Systems } \\
\hline $\begin{array}{l}\text { Leak from piping, } \\
\text { valve, or pump } \\
\text { outside of tank }\end{array}$ & $\begin{array}{l}\text { Random component } \\
\text { failure }\end{array}$ & $3 b, 3 f, 4 a, 7 a, 7 b$ & Unlikely & $\begin{array}{l}\text { 1. Airborne release possible } \\
\text { 2. Up to thousands of gallons of supernate } \\
\text { could be released on the ground and would } \\
\text { go to White Oak Creek }\end{array}$ & \\
\hline $\begin{array}{l}\text { Transfer line } \\
\text { blockage }\end{array}$ & $\begin{array}{l}\text { Valve closed, kink in } \\
\text { hose }\end{array}$ & $2 b, 3 a, 3 f, 4 a, 7 a, 7 b$ & Anticipated & No release & \\
\hline \multicolumn{6}{|c|}{ HEPA Filter (Tank W-1A) } \\
\hline $\begin{array}{l}\text { Aerosols in tank } \\
\text { leak to } \\
\text { environment }\end{array}$ & $\begin{array}{l}\text { HEPA filters fail or } \\
\text { are improperly } \\
\text { installed }\end{array}$ & $6 \mathrm{~b}$ & Anticipated & $\begin{array}{l}\text { 1. Aerosols generated in the tank released } \\
\text { through tank vent line to the atmosphere }\end{array}$ & $\begin{array}{l}\text { Only small amounts of } \\
\text { aerosols could be generated } \\
\text { from the NTF and W-1 } 1 \\
\text { surveillance and maintenance } \\
\text { activities }\end{array}$ \\
\hline $\begin{array}{l}\text { Collected material } \\
\text { on the HEPA filter } \\
\text { released to the } \\
\text { environment }\end{array}$ & $\begin{array}{l}\text { Dropped HEPA } \\
\text { during change-out }\end{array}$ & $7 \mathrm{a}, 7 \mathrm{~b}$ & Unlikely & $\begin{array}{l}\text { 1. The HEPA filters will not have significant } \\
\text { accumulations of radioactive materials. The } \\
\text { consequences from a dropped HEPA will be } \\
\text { minimal }\end{array}$ & $\begin{array}{l}\text { The HEPA filters are changed } \\
\text { very infrequently since they } \\
\text { do not have forced flow } \\
\text { through them }\end{array}$ \\
\hline \multicolumn{6}{|c|}{ All Systems: Natural Phenomena and Man-Made Hazards } \\
\hline $\begin{array}{l}\text { Tank or transfer } \\
\text { piping leak. HEPA } \\
\text { filter rupture }\end{array}$ & Earthquake & $1 \mathrm{a}, 1 \mathrm{~b}, 4 \mathrm{a}, 3 \mathrm{~b}, 3 \mathrm{~d}, 3 \mathrm{~g}$ & Unlikely & $\begin{array}{l}\text { Same consequences as a tank leak or transfer } \\
\text { line leak }\end{array}$ & $\begin{array}{l}\text { No significant airborne } \\
\text { release for tank failures }\end{array}$ \\
\hline $\begin{array}{l}\text { Transfer piping } \\
\text { leak. HEPA filter } \\
\text { rupture }\end{array}$ & High wind & $4 a, 7 c$ & Unlikely & $\begin{array}{l}\text { No significant release is expected since the high } \\
\text { winds will not fail any of the buried } \\
\text { components }\end{array}$ & \\
\hline
\end{tabular}




\begin{tabular}{|c|c|c|c|c|c|}
\hline Event & Cause: & $\begin{array}{l}\text { Prevention/Detection/ } \\
\text { Mitigation }\end{array}$ & Frequency & Consequence & $\begin{array}{l}\text { Action liens } \\
\text { Comments: }\end{array}$ \\
\hline $\begin{array}{l}\text { Snow or ice } \\
\text { accumulates above } \\
\text { tanks, no release is } \\
\text { expected }\end{array}$ & Snow/Ice Loads & & Anticipated & $\begin{array}{l}\text { Tanks and equipment can withstand expected } \\
\text { loads without failure }\end{array}$ & $\begin{array}{l}\text { Snow/ice load sufficient to } \\
\text { cause failure is not credible }\end{array}$ \\
\hline $\begin{array}{l}\text { Transfer piping } \\
\text { leak }\end{array}$ & $\begin{array}{l}\text { Low Winter } \\
\text { Temperature }\end{array}$ & & Anticipated & $\begin{array}{l}\text { Possible freezing of transfer piping and support } \\
\text { piping. Pipe failures are discussed under "Leak } \\
\text { from primary confinement piping" entries }\end{array}$ & \\
\hline $\begin{array}{l}\text { Lightning strikes } \\
\text { ground above } \\
\text { tanks, no release is } \\
\text { expected }\end{array}$ & Lightning & & Unlikely & No release expected from lightning & \\
\hline Tank overfill & $\begin{array}{l}\text { Local flooding from } \\
\text { heavy rainfall. }\end{array}$ & $1 c, 3 a, 3 b, 3 d, 3 g, 5 a, 6 a$ & Anticipated & $\begin{array}{l}\text { 1. No significant airborne releases would occur } \\
\text { 2. Up to thousands of gallons of supernate } \\
\text { could be released on the ground and go to } \\
\text { White Oak Creek }\end{array}$ & \\
\hline $\begin{array}{l}\text { Flood does not } \\
\text { exceed tank tops' } \\
\text { elevation, no } \\
\text { release is expected }\end{array}$ & $\begin{array}{l}\text { Flood waters exceed } \\
\text { site grade: failure of } \\
\text { river dams. }\end{array}$ & & $\begin{array}{l}\text { Extremely } \\
\text { unlikely }\end{array}$ & None & $\begin{array}{l}\text { The dam failure causes } \\
\text { flooding to the } 800 \mathrm{ft} \\
\text { elevation. The tank tops are } \\
\text { above this elevation }\end{array}$ \\
\hline $\begin{array}{l}\text { Personnel are } \\
\text { forced to evacuated } \\
\text { tank area and } \\
\text { WOCC, no release } \\
\text { is expected }\end{array}$ & $\begin{array}{l}\text { Forced evacuation: } \\
\text { smoke, toxic } \\
\text { chemical releases, } \\
\text { radiation } \\
\text { emergencies, severe } \\
\text { weather, etc. } \\
\end{array}$ & $7 \mathrm{c}$ & Unlikely & $\begin{array}{l}\text { Tank farm is normally not manned. Operator } \\
\text { can terminate a transfer if forced to evacuate }\end{array}$ & $\begin{array}{l}\text { The system will be designed } \\
\text { to allow quick termination of } \\
\text { the transfer process. The } \\
\text { operators will be trained to } \\
\text { terminate operations prior to } \\
\text { evacuation }\end{array}$ \\
\hline $\begin{array}{l}\text { Tank or transfer } \\
\text { piping leak. HEPA } \\
\text { filter rupture }\end{array}$ & $\begin{array}{l}\text { Accidents involving } \\
\text { construction } \\
\text { equipment, trucks, } \\
\text { tankers, cranes, or } \\
\text { automobiles. }\end{array}$ & $1 \mathrm{a}, 4 \mathrm{a}, 4 \mathrm{~b}$ & Unlikely & $\begin{array}{l}\text { 1. Possible damage to above ground equipment } \\
\text { 2. HEPA filter contents could be released } \\
\text { 3. Other above ground components will not } \\
\text { cause a significant release }\end{array}$ & \\
\hline
\end{tabular}




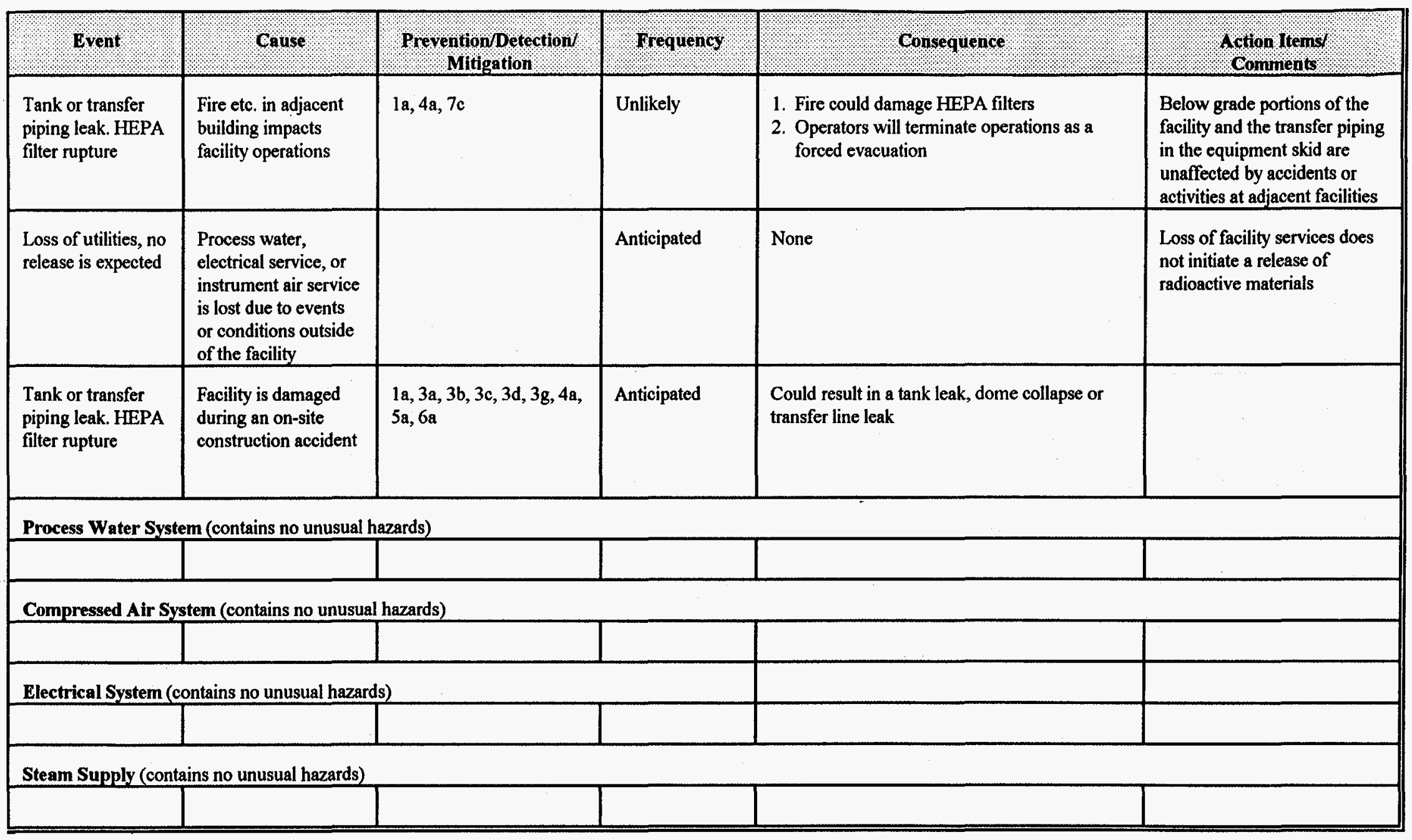




\section{D-9}

\section{Facility Design}

1. Barriers
a. Tanks located below grade.
b. Tanks are generally structurally sound.
c. Site is located on a hill side and will divert rainwater run-off away from tanks without significant accumulation.

2. Preventive Systems
a. Sampling indicates that the material is not a criticality hazard.
b. The discharge hoses can withstand full discharge pressure of the pump or the pump discharge has a relief valve to limit the pressure to below the hose rating.

3. Detection/Mitigative Systems
a. Tank level instrumentation (Tanks W-1A level checked at WOCC daily, Tank W-1 and W-2 checked daily, Tanks W-3 and W-4 checked weekly, and Tanks W-13, W-14, and W-15 are empty and inspected annually).
b. Spill response prevents ingestion dose.
c. Tank dry wells are monitored for leaks.
d. Dry wells drain to process waste pump station \#1, process waste pump station \#1 overflows to 3524 collection basin.
e. Tank W-1A vent has HEPA filters.
f. Above ground temporary transfer components and hoses will be doubly contained or inspectable.
g. Portable pumps available to transfer liquid from tank to another tank or active system.

\section{Administrative Features}

4. Procedural Restrictions or Limits Imposed
a.
b.
Operator present at facility during transfer operation to terminate a transfer if a leak occurs.
Heavy loads are not driven over the tanks.
c. New waste from outside the tank farm is not being added to the tanks.

5. Manual Monitoring of Critical Parameters

a. Weekly check of tank levels (for tanks containing liquid).

6. Equipment Support Functions (e.g., maintenance, calibration, etc.)
a. Maintenance program.
b. HEPA filters are tested for proper installation.

7. Operator Responses or Actions
a. Operator training.
b. Operating procedures.
c. Operator will stop a transfer if required to leave the area during a transfer. 


\section{APPENDIX E}

Treatability Study Preliminary Hazards Analysis 


\section{E-3}

\section{PRELIMINARY HAZARDS ANALYSIS}
AREA OF OPERATIONS:
Gunite and Associated Tanks Treatability Study
PROCESS/OPERATION:
Mobilize and transfer sludges between tanks W-3 and W-4

\section{HAZARDS OF INTEREST:}

See hazard identification tables in Appendix C.

\section{SYSTEMS:}

1. Tank W-3

2. Tank W-4

3. Modified Light Duty Utility Arm (MLDUA)

4. Remotely Operated Vehicle (ROV)

5. Waste Dislodging and Conveyance (WD\&C) system

6. Transfer piping skid

7. Ventilation system.

8. Process water (high and low pressure).

9. Compressed air.

10. Electrical system.

11. Decontamination spray system.

12. Control/administrative trailers.

13. Maintenance/decon area (temporary tent).

14. Closed circuit TV system.

\section{ENERGY SOURCES:}

1. Electrical energy associated with pumps, ventilation fans, air compressor, lights, and instrumentation.

2. Kinetic energy associated with the process water pumps; ventilation exhaust fans for tanks; air compressor; MLDUA, ROV, and WD\&C System movement; and high pressure water in confined sluicing end effector (CSEE), jet pump and decontamination spray.

3. Potential energy associated with the high pressure process water to CSEE, jet pump, and decontamination spray; elevated platform; MLDUA enclosure; WD\&C enclosure; and support cranes.

\section{OPERATIONS/PROCESSES/ACTIVITIES:}

1. Inserting, removing, and operating the MLDUA, WD\&C, and ROV.

2. Changing end effectors on MLDUA and ROV.

3. Mobilizing and transferring sludges between tanks.

4. Operating and maintaining closed circuit TV system.

5. Transferring supernate between tanks or to the Liquid Low-Level Waste System without mobilizing sludges.

6. Removing solid materials from the tanks

7. Sampling.

8. Maintenance/testing/modification.

9. Support systems (compressed air, process water, ventilation etc.) operations.

\section{BUILDING MODES:}

1) Operation Mode Inventory present and process water to CSEE or jet pump (when in tank) is not isolated.

2) Warm Standby Mode Inventory present and process water isolated to CSEE or jet pump (when in tank). 


\section{E-4}

MLDUA, ROV and WD\&C System powered up and process water which can cause tank to overflow not isolated.

3) Cold Standby Mode Inventory present and (1) process water isolated to CSEE or jet pump (when in tank) is isolated and (2) MLDUA, ROV and WD\&C System powered down and (3) all process water which can cause tank to overflow isolated.

\section{COMMENTS:}

The following release paths are considered in this analysis:

1) through cracks/penetrations/openings in the primary confinement piping into the transfer piping skid and from the transfer piping skid to the outside environment through cracks/penetrations/openings in the transfer piping skid,

2) through cracks/penetrations/openings in the tank to the outside environment,

3) from overfill of tanks to the outside environment,

4) from the primary confinement tanks from aerosols from sluicing or primary confinement leaks to the outside environment through the ventilation system,

5) from the transfer piping through process piping and instrumentation interfacing with the transfer piping to the outside environment. 


\begin{tabular}{|c|c|c|c|c|c|}
\hline Event & Cause & $\begin{array}{l}\text { Prevention } \\
\text { Detection' } \\
\text { Mitigation }\end{array}$ & Frequency & Consequence & $\begin{array}{l}\text { Actlon Items } \\
\text { Comments }\end{array}$ \\
\hline $\begin{array}{l}\text { Criticality accident } \\
\text { (Modes 1, 2, or } 3 \text { ) }\end{array}$ & $\begin{array}{l}\text { Critical mass of } \\
\text { fissile material } \\
\text { accumulates in } \\
\text { an unfavorable } \\
\text { geometry }\end{array}$ & $1 b, 2 i, 4 d$ & $\begin{array}{l}\text { Beyond } \\
\text { Extremely } \\
\text { Unlikely }\end{array}$ & None & $\begin{array}{l}\text { Sampling of the tanks } \\
\text { contents indicate that a } \\
\text { criticality accident is not } \\
\text { possible }\end{array}$ \\
\hline $\begin{array}{l}\text { Fire in tank } \\
\text { (Modes 1, 2, or 3) }\end{array}$ & $\begin{array}{l}\text { Combustible } \\
\text { material } \\
\text { introduced into } \\
\text { tank }\end{array}$ & $2 \mathrm{~d}, 3 \mathrm{a}, 4 \mathrm{~d}$ & $\begin{array}{l}\text { Extremely } \\
\text { Unlikely }\end{array}$ & $\begin{array}{l}\text { 1. HEPA filter will plug and negative } \\
\text { pressure may be lost }\end{array}$ & $\begin{array}{l}\text { Material in tanks is not } \\
\text { combustible }\end{array}$ \\
\hline $\begin{array}{l}\text { Leak from Tank } \\
\text { W-3 or W-4 } \\
\text { (Modes } 1,2 \text {, or } 3 \text { ) }\end{array}$ & Random failure & $\begin{array}{l}\text { lc, } 3 b, 3 c, 3 e, 3 h, 3 q \\
5 b, 6 a\end{array}$ & Unlikely & $\begin{array}{l}\text { 1. No airborne release } \\
\text { 2. Up to thousands of gallons of supernate } \\
\text { and suspended sludges could be } \\
\text { released }\end{array}$ & \\
\hline \multirow[t]{2}{*}{$\begin{array}{l}\text { Leak from Tank } \\
\text { W-3 or W-4 } \\
\text { (Modes } 1 \text { or } 2 \text { ) }\end{array}$} & $\begin{array}{l}\text { MLDUA, ROV, } \\
\text { or WD\&C drop } \\
\text { large component } \\
\text { into tank. } \\
\text { MLDUA, ROV, } \\
\text { or WD\&C } \\
\text { impact the tank } \\
\text { wall }\end{array}$ & $\begin{array}{l}1 c, 2 b, 3 b, 3 c, 3 e, 3 h \\
3 p, 3 q, 5 b, 6 a, 7 a, 7 b\end{array}$ & Unlikely & $\begin{array}{l}\text { 1. No airborne release } \\
\text { 2. Crack bottom of the tank slowly } \\
\text { releasing the contents }\end{array}$ & \\
\hline & $\begin{array}{l}\text { Mast housing } \\
\text { falls from } \\
\text { random failure, } \\
\text { operator error }\end{array}$ & $\begin{array}{l}1 b, 1 c, 3 b, 3 c, 3 e, 3 h \\
3 p, 3 q, 6 a, 7 a, 7 b\end{array}$ & Unlikely & $\begin{array}{l}\text { 1. Transfer piping and equipment } \\
\text { enclosure damaged }\end{array}$ & $\begin{array}{l}\text { The housing mast will not } \\
\text { be raised or lowered } \\
\text { during transfer operations }\end{array}$ \\
\hline
\end{tabular}




\begin{tabular}{|c|c|c|c|c|c|}
\hline Event & Cause & $\begin{array}{l}\text { Prevention/ } \\
\text { Detection/ } \\
\text { Mitigation }\end{array}$ & Frequency & Congequence. & $\begin{array}{l}\text { Action Items } \\
\text { Comments }\end{array}$ \\
\hline $\begin{array}{l}\text { Tank overfill } \\
\text { (Modes } 1 \text { or } 2 \text { ) }\end{array}$ & $\begin{array}{l}\text { Isolation valve } \\
\text { left open or fails } \\
\text { open. Process } \\
\text { water flows } \\
\text { unchecked into } \\
\text { tank from } \\
\text { flushing, } \\
\text { decontamination } \\
\text { ring spray left on } \\
\text { etc. }\end{array}$ & $\begin{array}{l}3 \mathrm{~b}, 3 \mathrm{c}, 3 \mathrm{e}, 3 \mathrm{~h}, 3 \mathrm{q}, 5 \mathrm{~b} \\
6 \mathrm{a}, 7 \mathrm{a}, 7 \mathrm{~b}, 7 \mathrm{~d}\end{array}$ & Unlikely & $\begin{array}{l}\text { 1. No significant airborne release } \\
\text { 2. Up to thousands of gallons of supernate } \\
\text { and suspended sludges could be } \\
\text { released }\end{array}$ & $\begin{array}{l}\text { Tank overflow likely to go } \\
\text { to dry wells }\end{array}$ \\
\hline \multicolumn{6}{|c|}{ Waste Dislodging and Conveyance System and Transfer Piping } \\
\hline $\begin{array}{l}\text { Leak from piping } \\
\text { or valve outside of } \\
\text { tank } \\
\text { (Mode 1) }\end{array}$ & $\begin{array}{l}\text { Random } \\
\text { component } \\
\text { failure }\end{array}$ & $3 a, 3 f, 7 d$ & Unlikely & $\begin{array}{l}\text { 1. Release of up to several hundreds of } \\
\text { gallons transfer piping skid or WD\&C } \\
\text { enclosure }\end{array}$ & $\begin{array}{l}\text { Negative pressure in } \\
\text { WD\&C and transfer pipe } \\
\text { enclosure provided by tank } \\
\text { ventilation system }\end{array}$ \\
\hline $\begin{array}{l}\text { Leak from piping, } \\
\text { valve, or pump } \\
\text { inside of tank } \\
\text { (Mode 1) }\end{array}$ & $\begin{array}{l}\text { Random } \\
\text { component } \\
\text { failure }\end{array}$ & $3 a, 3 p, 7 d$ & Unlikely & $\begin{array}{l}\text { 1. Release of up to several gallons as } \\
\text { aerosols inside the tank }\end{array}$ & \\
\hline $\begin{array}{l}\text { Transfer line } \\
\text { blockage } \\
\text { (Mode 1) } \\
\end{array}$ & $\begin{array}{l}\text { Valve closed, } \\
\text { sludges settle }\end{array}$ & $2 e$ & Anticipated & No release & \\
\hline $\begin{array}{l}\text { Interfacing line } \\
\text { open } \\
\text { (Mode 1) }\end{array}$ & $\begin{array}{l}\text { Component } \\
\text { failure, operator } \\
\text { error }\end{array}$ & $2 \mathrm{f}, 2 \mathrm{~g}, 3 \mathrm{k}$ & Anticipated & No release & \\
\hline $\begin{array}{l}\text { Release of liquid } \\
\text { from sample bottle } \\
\text { (Modes } 1 \text { and 2) }\end{array}$ & $\begin{array}{l}\text { Sample bottle } \\
\text { dropped at } \\
\text { containment box } \\
\text { panel, operator } \\
\text { error }\end{array}$ & $7 \mathrm{a}, 7 \mathrm{~b}$ & Anticipated & $\begin{array}{l}\text { 1. Minor airborne release } \\
\text { 2. Surface contamination }\end{array}$ & \\
\hline
\end{tabular}




\begin{tabular}{|c|c|c|c|c|c|}
\hline Event & Cause & $\begin{array}{l}\text { Prevention/ } \\
\text { Detection/ } \\
\text { Mitigation } \\
\end{array}$ & Frequency & Consequence & $\begin{array}{l}\text { Action Items/ } \\
\text { Comments }\end{array}$ \\
\hline \multicolumn{6}{|l|}{ Ventilation System } \\
\hline \multirow[t]{3}{*}{$\begin{array}{l}\text { Aerosols in tank } \\
\text { leak to environment } \\
\text { (Modes } 1 \text { or 2) }\end{array}$} & $\begin{array}{l}\text { Loss of negative } \\
\text { pressure during } \\
\text { normal } \\
\text { operations, i.e, } \\
\text { no access ports } \\
\text { open (fan stops, } \\
\text { closed dampers, } \\
\text { plugged filters, } \\
\text { exhaust duct } \\
\text { collapses) } \\
\end{array}$ & $3 \mathrm{i}, 3 \mathrm{j}, 7 \mathrm{~d}$ & Anticipated & $\begin{array}{l}\text { 1. No significant inhalation consequence } \\
\text { 2. Small airborme release of aerosols from } \\
\text { tank openings }\end{array}$ & \\
\hline & $\begin{array}{l}\text { Loss of air inflow } \\
\text { with access open } \\
\text { (fan stops, closed } \\
\text { dampers, } \\
\text { plugged filters, } \\
\text { exhaust duct } \\
\text { collapses second } \\
\text { access opened) } \\
\end{array}$ & $4 c, 5 a, 7 d, 7 g$ & Anticipated & $\begin{array}{l}\text { 1. No significant inhalation consequence } \\
\text { 2. Small airborne release of aerosols from } \\
\text { tank openings }\end{array}$ & $\begin{array}{l}\text { Sluicing and operation of } \\
\text { the decontamination spray } \\
\text { rings will not be permitted } \\
\text { when an access port is } \\
\text { opened without } \\
\text { compensatory measures } \\
\text { for aerosol control }\end{array}$ \\
\hline & $\begin{array}{l}\text { HEPA filters fail } \\
\text { or are improperly } \\
\text { installed }\end{array}$ & $3 j, 6 a, 6 b$ & Anticipated & $\begin{array}{l}\text { 1. The confined head sluicing system does } \\
\text { not generate significant amounts of the } \\
\text { aerosols }\end{array}$ & \\
\hline $\begin{array}{l}\text { Collected material } \\
\text { on the HEPA filter } \\
\text { released to the } \\
\text { environment } \\
\text { (Mode 3) }\end{array}$ & $\begin{array}{l}\text { Dropped HEPA } \\
\text { during change- } \\
\text { out }\end{array}$ & $6 a, 3 n, 7 a, 7 b$ & Anticipated & $\begin{array}{l}\text { 1. The HEPA is not likely to be changed } \\
\text { during the treatability study } \\
\text { 2. A release would only have local } \\
\text { impacts }\end{array}$ & \\
\hline
\end{tabular}




\begin{tabular}{|c|c|c|c|c|c|}
\hline Event & Cause & $\begin{array}{l}\text { Prevention/ } \\
\text { Detection/ } \\
\text { Mitigation }\end{array}$ & Frequency & Consequence & $\begin{array}{l}\text { Action Itemsl } \\
\text { Comments }\end{array}$ \\
\hline \multicolumn{6}{|c|}{ All Systems: Natural Phenomena and Man-Made Hazards } \\
\hline $\begin{array}{l}\text { Tank or transfer } \\
\text { piping leak } \\
\text { (Modes } 1,2 \text {, or } 3 \text { ) }\end{array}$ & Earthquake & $\begin{array}{l}1 \mathrm{a}, 1 \mathrm{c}, 3 \mathrm{c}, 3 \mathrm{e}, 3 \mathrm{f}, 3 \mathrm{~h} \\
3 \mathrm{q}, 7 \mathrm{~d}\end{array}$ & Unlikely & $\begin{array}{l}\text { 1. Tanks and containment equipment can } \\
\text { withstand earthquake without failure }\end{array}$ & $\begin{array}{l}\text { Facility structure and } \\
\text { system withstand a PC-2 } \\
\text { earthquake }\end{array}$ \\
\hline $\begin{array}{l}\text { Transfer piping } \\
\text { leak } \\
\text { (Modes } 1,2 \text {, or } 3 \text { ) }\end{array}$ & High wind & $1 \mathrm{a}, 1 \mathrm{~b}, 3 \mathrm{f}, 7 \mathrm{e}$ & Unlikely & $\begin{array}{l}\text { 1. Tanks and equipment can withstand } \\
\text { winds without failure }\end{array}$ & $\begin{array}{l}\text { Facility structure and } \\
\text { system withstand a PC-2 } \\
\text { level wind. Tanks are } \\
\text { located below grade } \\
\end{array}$ \\
\hline $\begin{array}{l}\text { Snow or ice } \\
\text { accumulated on } \\
\text { tanks and } \\
\text { equipment, no } \\
\text { release is expected }\end{array}$ & Snow/lce Loads & $1 \mathrm{a}, 1 \mathrm{~b}, 1 \mathrm{c}$ & Anticipated & $\begin{array}{l}\text { 1. Tanks and equipment can withstand } \\
\text { expected loads without failure }\end{array}$ & $\begin{array}{l}\text { Snow/ice load sufficient to } \\
\text { cause failure is not } \\
\text { credible }\end{array}$ \\
\hline $\begin{array}{l}\text { Transfer piping } \\
\text { leak } \\
\text { (Modes } 1,2 \text { or } 3 \text { ) }\end{array}$ & $\begin{array}{l}\text { Low Winter } \\
\text { Temperature }\end{array}$ & $7 \mathrm{a}, 3 \mathrm{f}$ & Anticipated & $\begin{array}{l}\text { 1. Possible freezing of transfer piping and } \\
\text { support piping. Pipe failures are } \\
\text { discussed under "Leak from primary } \\
\text { confinement piping" entries }\end{array}$ & $\begin{array}{l}\text { Tanks are located below } \\
\text { grade }\end{array}$ \\
\hline $\begin{array}{l}\text { Lightning strikes } \\
\text { equipment, no } \\
\text { release is expected }\end{array}$ & Lightning & $1 b, 1 c, 2 b$ & Unlikely & $\begin{array}{l}\text { 1. Potential electrical system upsets and } \\
\text { damage to ventilation system } \\
\text { 2. Lightning could also damage the } \\
\text { MLDUA, ROV, WD\&C control system }\end{array}$ & $\begin{array}{l}\text { Lightning strike will not } \\
\text { cause failure of primary } \\
\text { confinement system } \\
\text { components located inside } \\
\text { of equipment skid }\end{array}$ \\
\hline $\begin{array}{l}\text { Tank overfill } \\
\text { (Modes } 1,2 \text {, or } 3 \text { ) }\end{array}$ & $\begin{array}{l}\text { Local flooding } \\
\text { from heavy } \\
\text { rainfall }\end{array}$ & $1 d, 3 h, 3 q$ & Anticipated & None & $\begin{array}{l}\text { Most equipment located } \\
\text { on platform above tanks. } \\
\text { The HEPA filters and } \\
\text { other ventilation system } \\
\text { components will not be } \\
\text { affected by heavy rains }\end{array}$ \\
\hline
\end{tabular}




\begin{tabular}{|c|c|c|c|c|c|}
\hline Event & Cause & $\begin{array}{l}\text { Prevention/ } \\
\text { Detectioni/ } \\
\text { Mitigation }\end{array}$ & Frequency & Consequence & $\begin{array}{l}\text { Action Itens! } \\
\text { Comments }\end{array}$ \\
\hline $\begin{array}{l}\text { Personnel are } \\
\text { forced to evacuate } \\
\text { treatability study } \\
\text { area, no release is } \\
\text { expected }\end{array}$ & $\begin{array}{l}\text { Forced } \\
\text { evacuation: } \\
\text { smoke, toxic } \\
\text { chemical } \\
\text { releases, } \\
\text { radiation } \\
\text { emergencies, } \\
\text { severe weather, } \\
\text { etc. }\end{array}$ & $7 \mathrm{a}, 4 \mathrm{a}, 7 \mathrm{~d}$ & Unlikely & $\begin{array}{l}\text { 1. Sufficient time exists to terminate } \\
\text { operations }\end{array}$ & $\begin{array}{l}\text { The system will be } \\
\text { designed to allow quick } \\
\text { termination of the transfer } \\
\text { process. The operators } \\
\text { will be trained to terminate } \\
\text { operations prior to } \\
\text { evacuation }\end{array}$ \\
\hline $\begin{array}{l}\text { Tank or transfer } \\
\text { piping leak. HEPA } \\
\text { filter rupture } \\
\text { (Modes } 1,2 \text {, or } 3 \text { ) }\end{array}$ & $\begin{array}{l}\text { Accidents } \\
\text { involving } \\
\text { construction } \\
\text { equipment, } \\
\text { trucks, tankers, } \\
\text { cranes, or } \\
\text { gutomobiles } \\
\end{array}$ & $1 b, 3 e, 3 f, 3 g, 3 h, 7 d$ & Unlikely & $\begin{array}{l}\text { 1. Possible damage to ventilation systems } \\
\text { components including HEPA filters }\end{array}$ & $\begin{array}{l}\text { Vehicles traveling past the } \\
\text { tank farm will be moving } \\
\text { relatively slowly }\end{array}$ \\
\hline $\begin{array}{l}\text { Tank or transfer } \\
\text { piping leak. HEPA } \\
\text { filter nupture } \\
\text { (Modes } 1,2 \text {, or } 3 \text { ) }\end{array}$ & $\begin{array}{l}\text { Fire etc. in } \\
\text { adjacent building } \\
\text { impacts facility } \\
\text { operations }\end{array}$ & $1 b, 3 f, 7 a, 4 a, 7 d$ & Unlikely & $\begin{array}{l}\text { 1. Fire could damage ventilation system } \\
\text { equipment including HEPA filters } \\
\text { 2. Operators will terminate operations as a } \\
\text { forced evacuation }\end{array}$ & $\begin{array}{l}\text { Below grade portions of } \\
\text { the facility and the transfer } \\
\text { piping in the equipment } \\
\text { skid are unaffected by } \\
\text { accidents or activities at } \\
\text { adjacent facilities }\end{array}$ \\
\hline
\end{tabular}




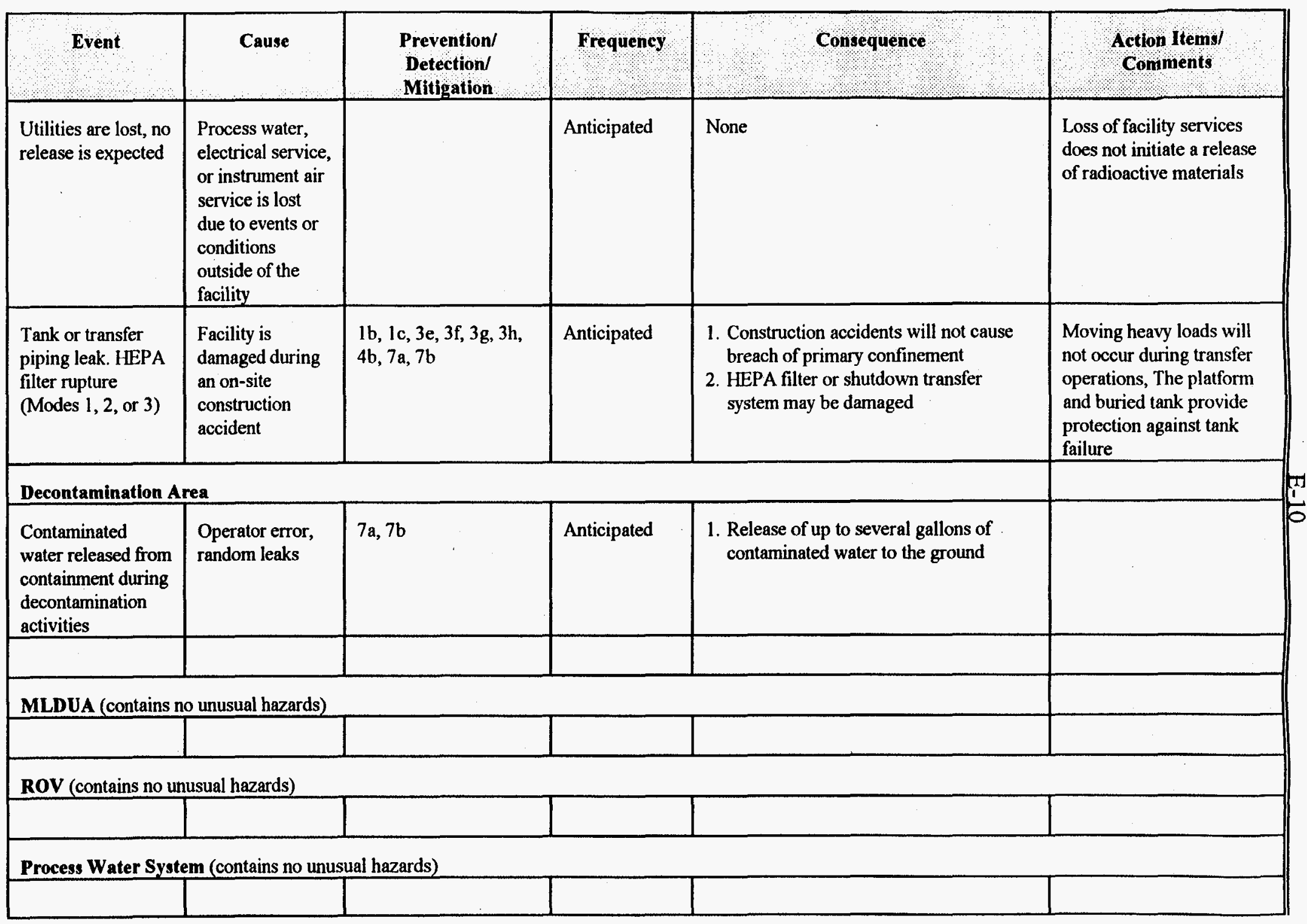




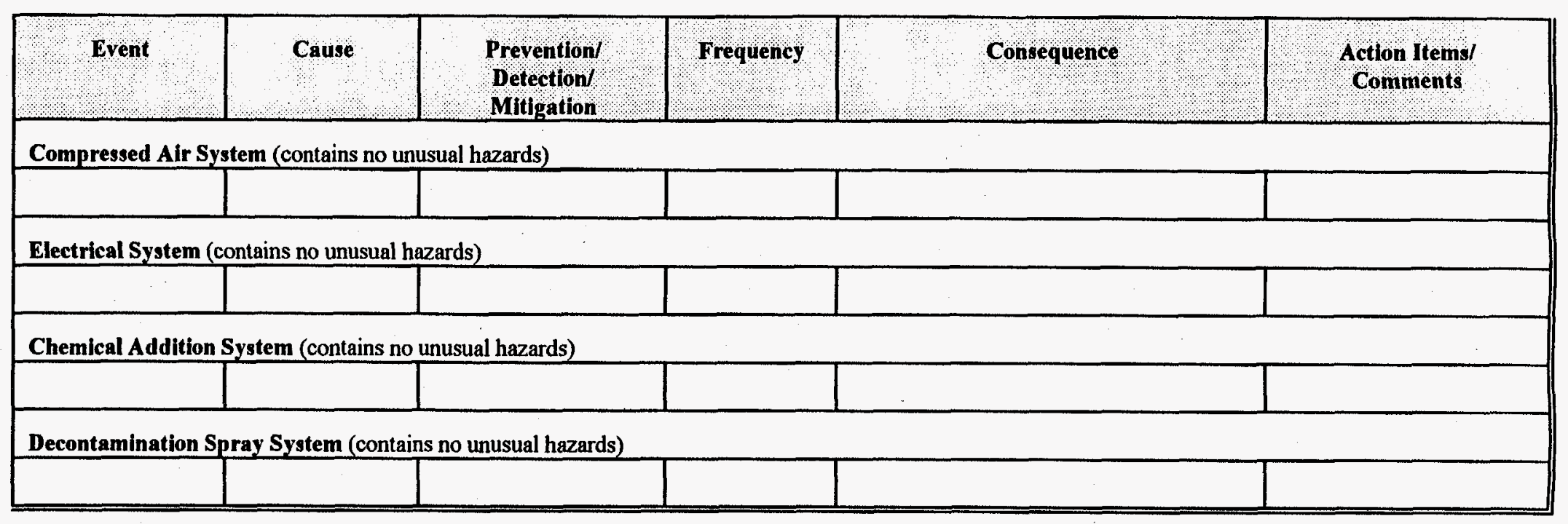




\section{Facility Design}

1.

Barriers

a. System structural design can withstand the effects without failure.

b. Tanks located below grade.

c. Tanks are generally structurally sound.

d. Site is located on a hill side and will divert rainwater run-off away from tanks without significant accumulation.

2. Preventive Systems

a. The components are located above the elevation that is flooded from dam failure.

b. The MLDUA does not have control failure modes that could result in large impacts to the tank walls or floors.

c. The ventilation system ensures air inflow at tank openings.

d. The hydraulic fluid in the MLDUA and vehicle has small quantities and it is not highly combustible.

e. Jet pump shutoff head not greater than the piping design pressure. Piping has a rupture disc for protection against overpressure.

f. The operating pressure of an interfacing system is higher than the operating pressure of the transfer piping.

g. The interfacing system has a check valve at the interface to prevent reverse flow.

h. Fan is sized such that it can not cause damage to the radioactive material confinement boundary.

I. Sampling indicates that the material is not a criticality hazard.

3. Detection/Mitigative Systems

a. When tank ventilation system operates, a HEPA filter cleans the discharge path.

b. Tank level instrumentation.

c. Spill response prevents ingestion dose.

d. Deleted.

e. Tank dry wells are monitored for leaks.

f. The transfer piping skid and WD\&C will collect leakage and direct it back to one of the tanks.

g. (7f) The sluicing and transfer operations can be terminated by more that one control point.

h. Dry wells drain to process waste pump station \#1.

I. The tank has pressure measurement which includes an alarm.

j. The HEPA filters and fan have differential pressure instrumentation.

k. The process water system line interfacing with the transfer line has a pressure instrument with an alarm.

1. The inlet to the fan has a pressure relief weighted damper.

m. Deleted.

n. Pre-filter and HEPA filter and housing are included as one replaceable unit.

o. Deleted

p. Camera can allow visual monitoring of important components.

q. Portable pump is available to transfer liquid from tanks to other tanks or to active systems.

\section{Administrative Features}

4. Procedural Restrictions or Limits Imposed

a. Process water normally isolated.

b. Operator present at facility during operation in modes 1 and 2 .

c. Total area of openings is limited.

d. New waste from outside the tank farm is not being added to the tanks.

e. No loads greater than several hundreds of pounds are lifted or moved during Mode 1 . 


\section{E-13}

5. Manual Monitoring of Critical Parameters

a. Inflow rate will be measured upon opening the access port and periodically thereafter as necessary.

b. Monitoring of the tank levels.

6. Equipment Support Functions (e.g., maintenance, calibration, etc.)
a. Maintenance program.
b. HEPA filters are tested for proper installation.

7. Operator Responses or Actions
a. Operator training.
b. Operating procedures.
c. Deleted.
d. The system design will allow quick termination of operations.
c. If the expected wind speed exceed the limits for the MLDUA enclosure for the erected position, it will be lowered.
f. $(3 \mathrm{~g})$ The sluicing and transfer operations can be terminated by more that one control point.
g. The operating procedures will ensure ventilation system operation prior to opening large accesses. 


\section{DISTRIBUTION}

1. L. V. Asplund

2. S. A. Herron

3. L. Holder

4. M. W. Kohring

5-6. D. M. Matteo

7. R. S. McKeehan

8. R. R. Morgan

9. P. T. Owen

10. J. H. Platfoot

11. P. A. Schrandt

12. S. D. Van Hoesen

13. M. L. Whitehead

14. Central Research Library

15. EMEF Document Management Center-RC 